UNIVERSIDADE DE SÃO PAULO

INSTITUTO DE PSICOLOGIA

Curso de Pós-Graduação em Psicologia

\title{
A Construção Social dos Discursos sobre o Acidente de Trabalho
}

Fábio de Oliveira 


\title{
A Construção Social dos Discursos sobre o Acidente de Trabalho
}

Fábio de Oliveira

\begin{abstract}
Dissertação apresentada ao Instituto de Psicologia da Universidade de São Paulo, como parte dos requisitos para obtenção do grau de Mestre em Psicologia. Área de concentração: Psicologia Social.

Orientador: Prof. Dr. Sigmar Malvezzi.
\end{abstract}

COMISSÃO JULGADORA:

Professora Doutora Mary Jane Paris Spink

Professora Doutora Arakcy Martins Rodrigues

Professor Doutor Sigmar Malvezzi 
Ao Gezonias, meu pai, ex-encanador, ex-vigia, ferramenteiro.

À Terezinha, minha mãe, ex-babá, ex-vendedora, professora primária.

A todos os trabalhadores que sempre lutaram por dignidade e por melhores condições de vida e de trabalho. 


\section{AGRADECIMENTOS}

- Ao Prof. Dr. Sigmar Malvezzi, por acolher sem restrições esta pesquisa e pela confiança que depositou em mim.

- À Prof. Leny Sato, mentora intelectual, amiga e companheira de trabalho, pela influência que teve em meus caminhos através da psicologia e pela sua presença constante e esclarecedora a cada passo da realização desta pesquisa.

- A todos os amigos do saudoso PST-ZN, especialmente: Maria Maeno, Felipe, Kal, Celinha, Lúcia, Alexandre Bonetti, Mírian Pedrollo e Paulo. Não é exagero dizer que sou cria do PST-ZN, pois foi na convivência cotidiana com essas pessoas queridas e no compartilhar seus ideais que encontrei terreno fértil para pensar a psicologia social.

- Aos diretores de saúde do sindicato dos trabalhadores metalúrgicos da região estudada - sem os quais esta pesquisa não teria sido possível - por reconhecerem a importância de meu trabalho, pela sua grande disposição em colaborar e pela indicação da empresa-caso.

- Aos operários e aos profissionais da equipe de segurança da empresa-caso, que foram meus interlocutores em longas discussões sobre os acidentes de trabalho e não mediram esforços para contribuir com esta pesquisa.

- À Jaqueline, companheira no amor e na militância, pela sua maneira delicada e profundamente ética de encarar o mundo, pelo carinho, pela companhia, pela compreensão e pela leitura crítica e cuidadosa de meu trabalho.

- À Prof. Dra. Arakcy Martins Rodrigues, por ter reconhecido tão bem minhas intenções, pela leitura cuidadosa e carinhosa de meu trabalho.

- À Prof. Dra. Mary Jane P. Spink, pelo seu espírito inquieto que tem aberto novas fronteiras na psicologia social brasileira e instigado jovens pesquisadores a acompanhá-la, pela leitura atenta de meu trabalho e pelos excelentes textos que me indicou.

- À Renata Paparelli, pela amizade, pela paciência e pela companhia em longas discussões epistemológico-políticas, refletidas em muitas páginas desta dissertação.

- À Lúcia Fonseca de Toledo, pela sua alegria, pela amizade - fortificada nos ideais que compartilhamos - e pela leitura da versão final deste trabalho.

- Ao Chico Lacaz, pelas valiosas referências bibliográficas que indicou. 
- À Prof. Dra. Eda Tassara, pela leitura da primeira versão do projeto que deu origem a esta dissertação e por incentivar-me a prosseguir.

- À Ana Lúcia, Cida, Cybelle, Eliane, Fátima, Ilidio, Regina, Rodrigo e às outras pessoas que me auxiliaram no árduo trabalho de transcrição das entrevistas.

- Aos alunos e aprimorandos que fizeram pesquisas sob minha supervisão em seus estágios no CPAT, pelo seu entusiasmo e pelas divertidas discussões sobre psicologia social e metodologia, que ajudaram a amadurecer as idéias apresentadas neste trabalho.

- Às pessoas que ficaram nos bastidores, amparando-me com sua simpatia e o sempre oportuno apoio logístico: Cecília, Nalva, Fátima e Vera.

- Às amigas Eliane e Mirna, pela amizade de muitos anos que nos une e pela paciência que tiveram com minhas expressões bem humoradas de descontentamento com a psicologia, as quais espero que compreendam, ao menos em parte, depois de lerem as páginas que se seguem.

- Ao Wilson, do Diesat, que colaborou com o levantamento de textos jornalísticos.

- Ao Instituto de Saúde da Secretaria de Estado da Saúde de São Paulo, que me dispensou das atividades no Núcleo de Investigação em Trabalho e Saúde para a realização desta pesquisa, na época em que eu ainda fazia parte de seu quadro profissional.

- À Fapesp, pela excelência de sua assessoria técnica, pela disciplina dos relatórios semestrais, por permitir-me o privilégio de passar um ano de minha vida dedicando-me exclusivamente aos livros e às incursões a campo e por ter financiado parcialmente este trabalho (processos Fapesp

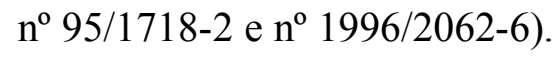


Oliveira, F. de (1997). A Construção Social dos Discursos sobre o Acidente de Trabalho. São Paulo, 125 p., Dissertação de Mestrado apresentada ao Departamento de Psicologia Social e do Trabalho do Instituto de Psicologia da Universidade de São Paulo.

\section{RESUMO}

Os acidentes de trabalho são conseqüência das formas pelas quais as sociedades produzem suas condições de existência e, ao mesmo tempo, constituem-se como objetos sociais a partir de construções teórico-práticas. Nesse segundo processo, tem-se constatado a existência de concepções calcadas em fatores pessoais ou psicológicos que responsabilizam os trabalhadores pelos acidentes. Considerando-se suas implicações para as políticas de saúde, as ações preventivas e reivindicatórias, investigou-se a presença dessas concepções nas práticas discursivas de trabalhadores industriais, procurando identificar os repertórios interpretativos e seus aspectos retóricos e argumentativos, por meio da análise de discurso.

Para tanto, realizou-se levantamento das teorias explicativas construídas no campo da acidentologia e da psicologia e investigou-se brevemente sua difusão no Brasil. Concomitantemente, realizou-se estudo de caso de empresa metalúrgica, com base em observações, conversas informais, levantamento de documentos e entrevistas confrontativas com vinte operários.

Constatou-se a presença marcante nos modos comuns de compreensão dos acidentes da Teoria dos Dominós de Heinrich e a predominância das explicações calcadas nos atos inseguros, sustentadas pela naturalização dos riscos e por práticas institucionalizadas de difusão. No entanto, a construção discursiva dos acidentes acontece de maneira dilemática, existindo contradições entre os diferentes repertórios interpretativos e a presença de eventos desnaturalizadores que produzem rupturas semânticas e manifestações de resistência.

Assim, a pesquisa revelou aspectos polissêmicos e retóricos das práticas discursivas que atribuem significados aos acidentes de trabalho. Revelou também a influência das idéias científicas e das práticas institucionais sobre os modos de compreensão desse fenômeno, o que aponta para a necessidade de construção de um discurso contra-hegemônico de contestação das idéias que responsabilizam os trabalhadores pelos acidentes de trabalho. 
Oliveira, F. de (1997). The Social Construction of Work Accidents Discourses. São Paulo, 125 p., Master Dissertation presented to Department of Social and Work Psychology, Psychology Institute, São Paulo University.

\begin{abstract}
Work accidents are the outcome of the ways societies produce the conditions of their existence, and, at the same time, become social objects through theoretical-practical constructions. In this second process, conceptions based on personal or psychological factors that picture workers as responsible for accidents have been verified. Considering consequences for health policy, preventive and vindication actions, these conceptions in industrial workers' discursive practices were investigated in an attempt to identify interpretative repertoires and their rhetoric and argumentative features.

Explanatory theories constructed in the field of accidentology and psychology were surveyed and appreciated and their diffusion in Brazil was briefly investigated. Simultaneously, a case study in a metallurgic company was conducted, based on observations, informal conversations, surveys of documents and interviews with twenty workers.

A pervasive presence of the Heinrich's Dominoes Theory was verified in the shared patterns of understanding and the predominance of accounts based on unsafe acts, sustained by naturalization of risks and institutionalized practices of diffusion. Nevertheless, the discursive construction of accidents occurs in a dillematic way, contradictions among the different repertoires and the presence of denaturalizer events both of which product semantic ruptures and manifestations of resistance were found out.

Thus, the research reviewed polyssemic and rhetoric features of the discursive practices which make sense of work accidents. It also reviewed the influence of scientific thinking and institutional practices on the accident understanding which points out the need of construction of counter-hegemonic discourse for the contestation of ideas that blame workers for work accidents.
\end{abstract}




\section{APRESENTAÇÃO}

Esta pesquisa é o resultado das inquietações sofridas por um psicólogo social que, não por acaso, aventurou-se pelo campo da saúde do trabalhador. Essa trajetória iniciou-se no Programa de Saúde dos Trabalhadores da Zona Norte ${ }^{1}$, passando pelo Núcleo de Investigação em Trabalho e Saúde do Instituto de Saúde da Secretaria de Estado da Saúde de São Paulo, até chegar ao Centro de Psicologia Aplicada ao Trabalho do Instituto de Psicologia da Universidade de São Paulo. A soma dessas experiências, como pesquisador e como psicólogo, permitiu conhecer diferentes contextos de trabalho, ter contato direto com trabalhadores e com os debates que povoam o campo da saúde do trabalhador.

Desses últimos, selecionou-se como tema da presente dissertação aquele que envolvia a disputa entre diferentes explicações para os acidentes de trabalho. Algumas razões conduziram a tal escolha. Primeiro, o fato de que as formas como os acidentes são compreendidos influenciam tanto as ações preventivas adotadas pelas empresas ou exigidas pelo Estado, quanto as reivindicações e propostas de trabalhadores e sindicatos. Portanto, compreender a formação dessas explicações e teorias, sejam elas científicas ou locais, torna-se uma contribuição valiosa para o estudo dos acidentes de trabalho, na medida em que lança luz sobre os processos de negociação social de sua definição e sobre o poder de convencimento de determinados modos de explicação.

Segundo, a constatação, por diversos pesquisadores, da permanência no dia-a-dia do chão de fábrica de explicações para os acidentes calcadas nos chamados "fatores individuais" ou “fatores psicológicos", que são utilizadas por empresários, trabalhadores e especialistas em higiene e segurança. Tal tipo de explicação, em geral, remete a conceitos já abandonados pela acidentologia, tais como "propensão a acidentes" e "atos inseguros", substituídos por modelos teóricos que buscam uma compreensão global da totalidade do fenômeno. A psicologia, embora não o tenha feito sozinha, colaborou muito para a construção dessas teorias: há muitas vozes no interior dessa ciência que denunciam a sua contribuição para uma visão estritamente psicológica e individualista da realidade, presente em diversos setores da vida social.

Pelas mesmas razões, optou-se, não por um estudo amplo e exploratório a respeito das concepções em geral sobre os acidentes, mas sim, pela investigação da presença ubíqua das explicações individualistas e psicologizantes nas produções discursivas cotidianas de

\footnotetext{
${ }^{1}$ Atualmente denominado Centro de Referência em Saúde do Trabalhador de São Paulo (CEREST/SP), vinculado à Secretaria de Estado da Saúde de São Paulo.
} 
trabalhadores industriais. Isso não significa que não tenhamos dado a devida atenção à diversidade e à polifonia dos discursos estudados: muito pelo contrário, as relações entre as diversas versões sobre os acidentes foram analisadas, justamente com o objetivo de compreender as formas pelas quais aquelas explicações sob foco eram desafiadas, modificadas ou reproduzidas.

Gostaríamos que este trabalho pudesse ser útil, tanto para profissionais do campo da saúde do trabalhador - que em seu dia-a-dia defrontam-se com explicações culpabilizadoras para os acidentes de trabalho - quanto para psicólogos interessados em desvendar o papel da psicologia na constituição dessas idéias e em compreender os processos cotidianos de construção da realidade social.

Quanto à divisão dos capítulos, procuramos, no primeiro, definir os objetivos da pesquisa e apontar a relevância do problema estudado, contrastando-se a gravidade dos acidentes de trabalho no país com a profusão de idéias que têm como conseqüência culpar os trabalhadores pelos seus próprios acidentes.

No capítulo 2 discutimos a idéia de construção social dos acidentes de trabalho, conceituando-os como decorrência da ação humana sobre o mundo e como produtos de práticas discursivas. Sem perder a tensão entre esses dois processos constitutivos da realidade social, incursionamos pelo debate construcionista, que nos auxiliou na formulação de um campo teórico a partir do qual pudéssemos compreendê-los.

O capítulo 3 apresenta a metodologia de investigação utilizada. A proposta de estudar discursos e práticas de trabalhadores levou-nos a delimitar um caso - uma empresa metalúrgica de grande porte - e investigar os contextos em que suas práticas discursivas tomam forma. Assim, buscamos conhecer as idéias sobre os acidentes em circulação em nossa sociedade através da identificação, na literatura especializada, das principais teorias acidentológicas e das formas pelas quais a psicologia abordou a questão. Em seguida, partimos para o campo movidos pelo objetivo de conhecer as práticas, institucionalizadas ou não, voltadas para os acidentes de trabalho e as formas pelas quais os trabalhadores atribuíam significado aos acidentes de trabalho e explicavam suas causas. Além de apresentarmos nesse capítulo os procedimentos utilizados para a realização do estudo de caso, fazemos também uma breve discussão da técnica de entrevista utilizada, que difere da forma tradicional em razão do referencial teórico adotado.

O capítulo 4 apresenta a síntese das principais teorias acidentológicas e das contribuições da psicologia para o tema. Em seguida, é traçado um breve panorama do debate científico e político no Brasil ocorrido ao longo do processo de desenvolvimento industrial, destacando-se a 
presença das idéias estritamente psicológicas e as políticas sociais que levaram à sua ampla difusão. Na primeira metade do século, período da instalação do parque industrial brasileiro, predominavam as idéias sobre a propensão ao acidente. Mais recentemente, a partir do chamado "milagre econômico", passam a predominar as concepções calcadas nos conceitos de ato inseguro e fatores humanos no trabalho.

Os resultados do trabalho de campo são discutidos no capítulo 5. Verificou-se a presença marcante do modelo heinrichiano nas formas de compreensão que alimentam os debates em torno dos acidentes de trabalho, de modo que ele constitui um lugar-comum a partir do qual as explicações são construídas. Essas assumem diversas formas e constituem diferentes versões dos acidentes de trabalho, a partir da contradição entre atos inseguros e condições inseguras, confrontados em um contexto fortemente argumentativo. O processo de naturalização dos riscos e a existência de práticas institucionalizadas de difusão contribuem para predominância das explicações centradas em fatores humanos. Porém, a natureza polissêmica dos discursos e a vivência dilemática dos acidentes promovem rupturas discursivas e práticas de resistências a essas concepções, ainda que elas permaneçam hegemônicas.

No capítulo 6, apresentamos as conclusões que puderam ser formuladas a partir desses resultados e tentamos avaliar as suas conseqüências para as políticas públicas em saúde do trabalhador e para o movimento sindical, fazendo algumas pequenas sugestões. 


\section{ÍNDICE}

1. INTRODUÇÃO

1.1. CONTRA UMA VISÃO ESTRIT AMENTE PSICOLÓGICA DO ACIDENTE DE TRABALHO ……...........................................

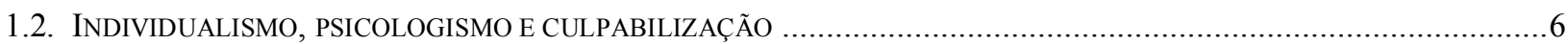

2. O ACIDENTE DE TRABALHO COMO CONSTRUÇÃO SOCIAL .............................................................8

2.1. O ACIDENTE DE TRABALHO COMO PRODUTO DA AÇ̃̃O HUMANA SOBRE O MUNDO …............................................9

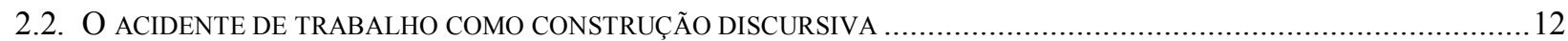

2.3. A IDEOLOGIA COMO RETÓRICA E COMO MODO OU ESTRATÉGIA DE DOMINAÇÃO................................................19

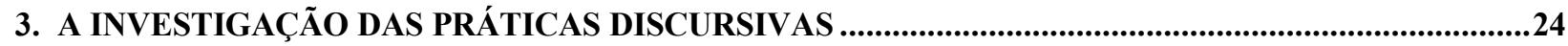

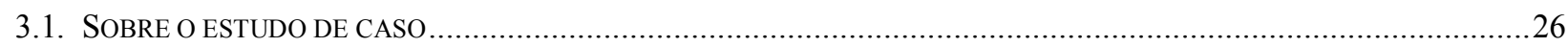

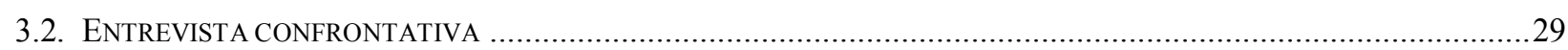

4. O ITINERÁRIO DAS IDÉIAS PSICOLOGIZANTES NO IMAGINÁRIO SOCIAL....................................34

4.1. AS TEORIAS DE ACIDENTABILIDADE E AS IDÉIAS PSICOLOGIZANTES................................................................34

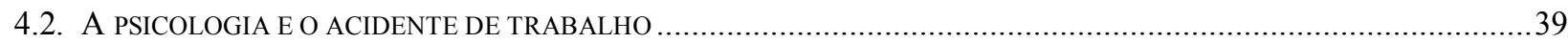

4.3. A DIFUSÃo DAS IDÉIAS PSICOLOGIZANTES SOBRE O ACIDENTE DE TRABALHO No BRASIL ..................................43

5. O ACIDENTE DE TRABALHO NO COTIDIANO: ESTUDO DE CASO DE EMPRESA

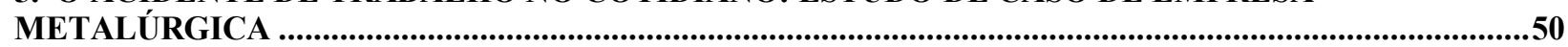

5.1. A EMPRESA-CASO: PROCESSO DE TRABALHO, RISCOS E ACIDENTES ............................................................51

5.1.1. Análise de acidentes, eliminação de riscos e "conscientização" dos trabalhadores................................54

5.1.2. A atuação da CIPA: correções ambientais e ação disciplinar ...............................................................59

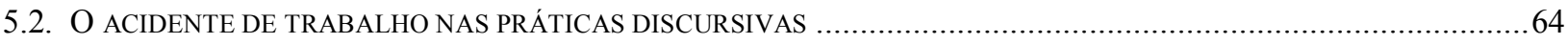

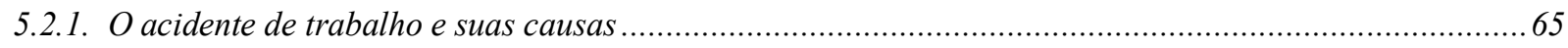

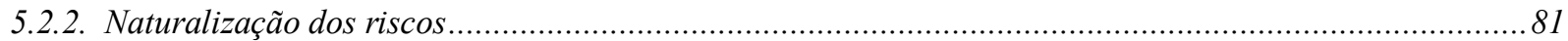

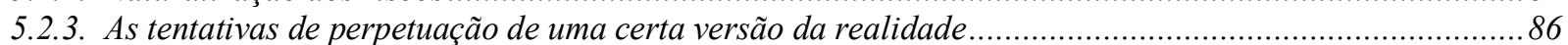

5.2.4. Rupturas e formas de resistência ........................................................................................ 96

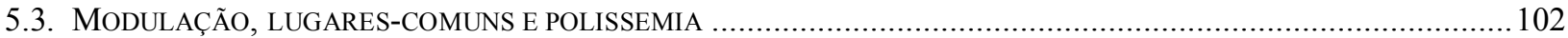

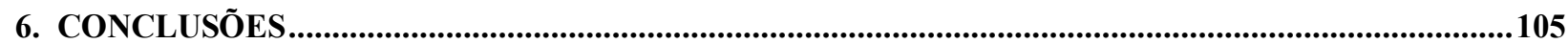

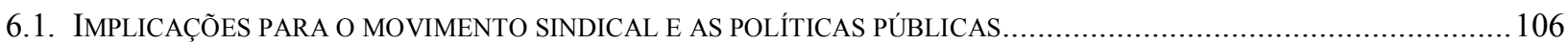

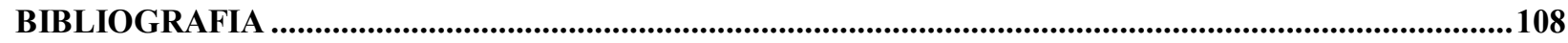

ANEXOS

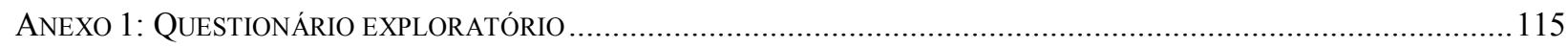

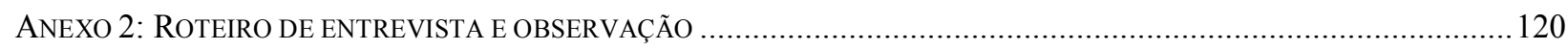




\section{ÍNDICE DE FIGURAS}

A POSSIBILIDADE DE MÚlTIPLAS REALIDADES DOS OBJETOS COMO PRESENTIFICAÇÃO DE “ALGUMA COISA NO MUNDO”13

A “TEORIA dOS DOMINÓs” DE HEINRICH. 36

A “TEORIA DOS DOMINÓs” PRESENTE EM APOSTILAS FORNECIDAS AOS TRABALHADORES DA METALCO ..... .88

\section{ÍNDICE DE GRÁFICOS}

COMPARAÇÃO ENTRE DISTRIBUIÇÃO ANUAL DE ACIDENTES DE TRABALHO NO BRASIL E ÍNDICE DE LETALIDADE, DE 1970 A 1991

Programa de Prevenção de Riscos Ambientais, MetalCo: Distribuição de Riscos levantados, Resolvidos E PENDENTES DURANTE O PERÍODO DE JULHO DE 1995 A JUNHO DE 1996.

\section{ÍNDICE DE TABELAS}

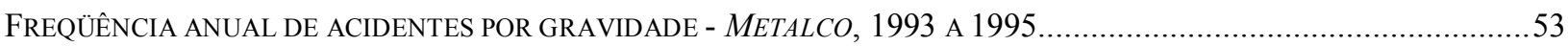

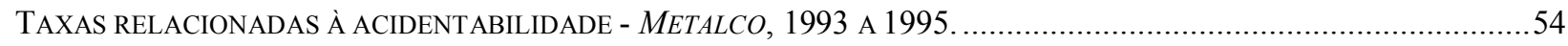

CONDIÇÕES INSEGURAS PRESENTES, SEGUNDO A ANÁLISE DOS TÉCNICOS DE SEGURANÇA, NOS ACIDENTES DO ANO DE 1995

ATOS INSEGUROS COMETIDOS, SEGUNDO A ANÁLISE dOS TÉCNICOS DE SEGURANÇA, PELOS TRABALHADORES ENVOLVIDOS NOS ACIDENTES DO ANO DE 1995.

FATORES PESSOAIS QUE, SEGUNDO A ANÁLISE DOS TÉCNICOS DE SEGURANÇA, TIVERAM RELAÇÃO COM OS ACIDENTES DO ANO DE 1995.

CAUSAS DOS ACIDENTES APONTADAS PELOS TRABALHADORES DA PRODUÇÃO PRESENTES EM CURSO OFERECIDO PELO SINDICATO - QUESTIONÁRIO EXPLORATÓRIO, N=38, 1996.

FORMAS DE PREVENÇÃO APONTADAS PELOS TRABALHADORES DA PRODUÇÃO PRESENTES EM CURSO OFERECIDO PELO SINDICATO - QUESTIONÁRIO EXPLORATÓRIO, N=38, 1996 


\section{INTRODUÇÃO}

Os acidentes de trabalho são um grave problema de saúde pública no Brasil. A inexistência de um sistema nacional de registro dificulta o conhecimento da situação real dos acidentes ocorridos em todo o território. Entretanto, dados da previdência social revelam que no ano de 1991, dentre os 22.792.858 trabalhadores brasileiros segurados até aquele ano, foram registrados 640.790 acidentes, dos quais 4.523 resultaram em mortes ${ }^{2}$. O gráfico a mostra que, embora exista uma tendência à diminuição da incidência de acidentes em geral no país, o índice de letalidade segue uma tendência inversa.

Gráfico A: Comparação entre distribuição anual de acidentes de trabalho no Brasil e índice de letalidade, de 1970 a 1991.

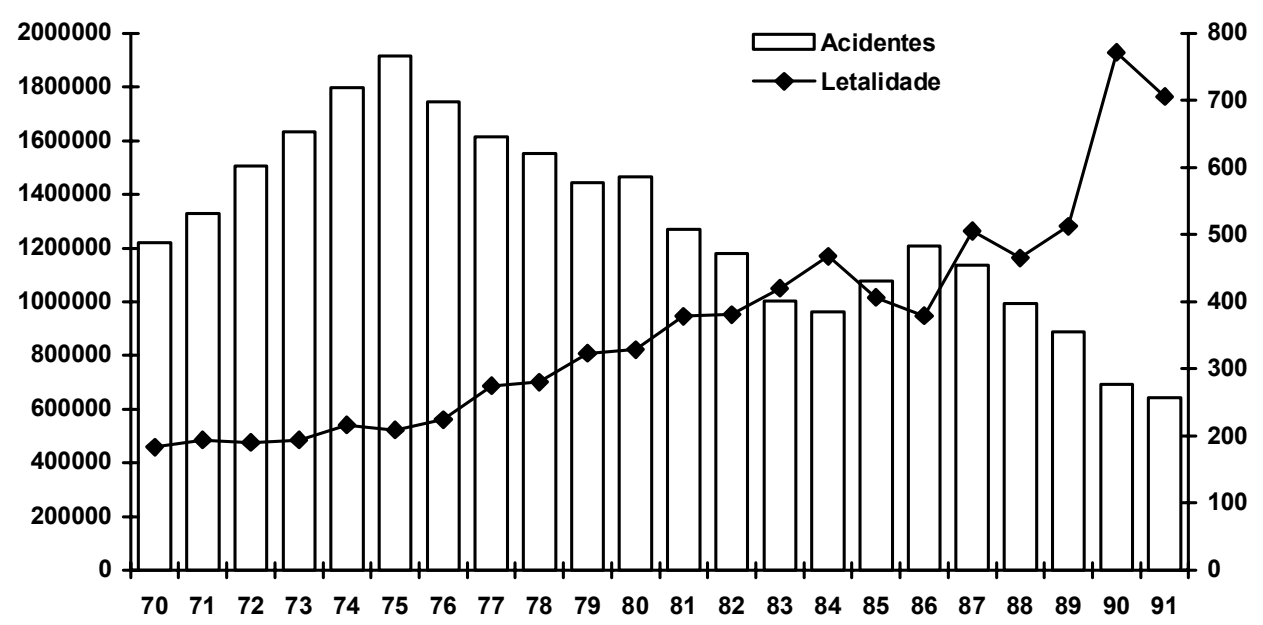

Fonte: Carmo \& cols. (1995).

Analisando essa diferença entre a diminuição do número total de acidentes e o aumento do índice de letalidade, Carmo \& cols. (1995) apontam para a possível subnotificação dos acidentes não-fatais, motivada por mudanças na legislação acidentária - que transferiu às empresas a obrigação da notificação e a responsabilidade pelo pagamento dos quinze primeiros dias de afastamento do trabalho - e pelo fim do pagamento diferenciado aos hospitais conveniados que atendiam acidentados. Deve-se salientar que os números oficiais não incluem os acidentes ocorridos no mercado informal de trabalho. Os acidentes fatais, pela dificuldade em

\footnotetext{
${ }^{2}$ Essas mortes referem-se àquelas ocorridas até o momento da notificação do acidente, que legalmente deve ser feita no prazo de 24 horas após sua ocorrência.
} 
serem ocultados, não sofreram essa influência e sua crescente incidência põe em dúvida a aparente diminuição dos acidentes em geral.

Ainda, se compararmos a taxa de acidentes fatais no Brasil com a de outros países, sem levar em conta a questão da subnotificação, enquanto Finlândia e México tiveram em 1990 taxas de 3,5 e 12,0, respectivamente, o Brasil atingiu a marca de 23,0 acidentes para cada 100.000 habitantes (Wünsch-Filho, 1994).

A simples apresentação desses dados aponta para a gravidade do problema em nosso país, para a insuficiência das medidas adotadas visando seu controle e para a necessidade de novas formas de enfrentamento do problema.

Não só no Brasil, mas em todo o mundo - pelas suas conseqüências para a saúde dos trabalhadores e para a produção - os acidentes de trabalho têm suscitado inúmeras respostas sociais, dentre as quais podemos citar: os protestos de trabalhadores ${ }^{3}$ e as ações sindicais denunciando condições perigosas de trabalho, reivindicando e propondo mudanças; as legislações trabalhistas e previdenciárias objetivando limitar a exposição a riscos para acidentes, indenizar os acidentados e garantir a recuperação de sua saúde; o desenvolvimento de técnicas para redução de acidentes e eliminação de riscos nos ambientes de trabalho; a construção de explicações para os acidentes - tanto nas ciências, quanto no cotidiano das fábricas - visando compreender suas causas. Muitas dessas respostas têm sido estudadas em diferentes perspectivas (por exemplo: Carmo \& cols., 1995; Cohn \& cols., 1985; Hirano \& cols., 1990), o presente trabalho procurará enfocar alguns aspectos dos modos pelos quais essas últimas - as explicações para os acidentes - são construídas.

Explicar as causas dos acidentes de trabalho não é tarefa das mais simples. Os termos sob os quais as explicações são feitas são mediados pelos sistemas de significação presentes no contexto onde são enunciadas. Diversas são as teorias criadas por especialistas de diferentes áreas para explicar o acidente de trabalho. Mas não são apenas os especialistas que constroem teorias: os trabalhadores no seu dia-a-dia discutem os acidentes, conferem sentido ao seu acontecimento e elaboram explicações, criando significados a partir daqueles disponíveis na cultura e na sua experiência, inclusive a partir das teorias construídas no campo científico. A presente pesquisa procurou compreender essa forma de conhecimento social, analisando a

\footnotetext{
${ }^{3}$ Embora com ênfases diferentes no decorrer da história do sindicalismo brasileiro, a luta por salários sempre esteve acompanhada pela luta por melhores condições de trabalho. São freqüentes os protestos isolados contra condições perigosas, motivados por mortes de operários durante o trabalho, como, por exemplo, o protesto dos funcionários da Volkswagen de São Bernardo do Campo, em 1996, pela morte do prensista Antônio Raimundo de Amorim, de 42 anos, esmagado pelo desabamento de parte da máquina que operava. Os operários cruzaram os braços e durante mais de uma hora interditaram a Via Anchieta (Folha de S. Paulo, 30/11/96). Outros exemplos similares: Firestone de Santo André (Diário Popular, 18/07/95), Tamet de Diadema (Diário Popular, 29/05/95).
} 
produção cotidiana de sentido e as marcas deixadas pelos diversos contextos nas práticas discursivas.

Entretanto, não serão analisadas, de maneira idêntica, todas as formas de explicações presentes nas práticas discursivas cotidianas: as perguntas da pesquisa perseguiram um conjunto particular de explicações - aquelas que atribuem o acidente a características individuais do trabalhador (psicológicas ou não) - e a justificativa para tal escolha é apresentada a seguir.

\subsection{Contra uma visão estritamente psicológica do acidente de trabalho}

Em sua análise do campo da saúde pública, Crawford (1977) fala da emergência de uma ideologia que culpa os indivíduos por suas doenças e que sugere que cada cidadão deveria ter maior cuidado e responsabilidade pela sua própria saúde. A psicologia, segundo o mesmo autor, contribuiu para a formação dessa visão de mundo:

A difusão de uma visão psicológica do mundo geralmente reforça o mascaramento da causação social. Embora o modelo psiquiátrico substitua explicações sociais por explicações naturais, os problemas ainda tendem a ser vistos como passíveis de mudança através da transformação pessoal - com ou sem terapia [...] A ideologia da responsabilidade individual pela saúde presta-se a essa forma de controle social de natureza psicológica. Da susceptibilidade aos comportamentos de risco, se não são um defeito moral, são ao menos um defeito psicológico. Qualquer nova evidência relacionando estados psicológicos à resistência ou à suscetibilidade a doenças e acidentes pode e será usada para atribuir mais responsabilidade ao indivíduo. Psicólogos industriais vêm sendo empregados com o propósito de que o melhor caminho para diminuir acidentes fabris, em vista dos altos custos das mudanças na produção, é intervir no plano individual [...] Finalmente, ao focalizar o indivíduo em vez do sistema econômico, a ideologia realiza seu clássico papel de obscurecer a estrutura de classes do trabalho [Crawford, 1977: p. 672].

Da mesma forma, Caplan \& Nelson (1973) apontam para a predominância de explicações individualizantes nas conclusões de pesquisas feitas por psicólogos a respeito de problemas sociais:

Demonstrou-se a existência de uma preocupação individualizante e de um viés de atribuição causal na pesquisa psicológica que, quando aplicados a problemas sociais, favorecem explicações em termos das características pessoais daqueles que sofrem o problema, ao mesmo tempo que desconsideram a possível influência de forças externas [...] não se está dizendo que as variáveis individuais são menos válidas ou etiologicamente menos importantes na compreensão dos problemas sociais [...] o leitor não deve concluir que se está cegamente enamorado por uma abordagem que enfatiza fatores ambientais em detrimento de fatores individuais. Isso seria um erro na direção oposta. Em vez disso, nosso interesse não é tanto pela verdade das proposições a respeito do comportamento humano, mas muito mais pelas conseqüências sociais, políticas, econômicas e humanas dessas proposições [p. 209]. 
Esse viés tem, segundo os mesmos autores, conseqüências fatais para as formas de intervenção propostas para a solução dos problemas estudados:

Assim, onde interpretações centradas no indivíduo proporcionam o fundamento sobre o qual a intervenção corretiva baseia-se, pouco precisa ser feito quanto aos fatores externos já que eles seriam provavelmente de pouca ou nenhuma importância na determinação de um tal comportamento [p. 200].

Grimberg (1988), por sua vez, identifica um viés semelhante nas explicações médicas para os agravos à saúde ocasionados pelo trabalho. No enfoque médico tradicional, a desconsideração das condições sociais sob as quais o processo saúde-doença manifesta-se conduz à desvinculação entre o adoecimento individual e seu contexto:

A partir dessa fragmentação homem-trabalho (cujo ponto de partida básico é a fragmentação indivíduo-relações sócio-históricas), a consideração do sujeito acabou por reduzir-se aos "fatores humanos" ou à noção de "ato inseguro". A esses se recorre para a explicação dos acidentes de trabalho remetendo a análise às "condições psicológicas", ao "estado de capacitação", ao "treinamento individual" ou a uma suposta "falta de consciência" dos trabalhadores em relação à segurança [p. 37].

Especificamente com relação aos estudos da realidade brasileira, Cohn \& cols. (1985) descrevem aquilo que denominaram de "ideologia da culpabilização" dos acidentados no trabalho, expressa, por exemplo, nas mensagens veiculadas em cartazes de segurança, como estas: "É proibido introduzir as mãos na máquina em movimento sob quaisquer circunstâncias"; “não se arrisque, outros dependem de você"; "Papai, não se acidente!” (p. 147).

Interpretações que responsabilizam os trabalhadores pelos acidentes também foram encontradas em pesquisa feita por Binder \& cols. (1994). Esses autores estudaram análises de acidentes feitas por Comissões Internas de Prevenção de Acidentes (CIPA) ${ }^{4}$ de três empresas do ramo metalúrgico. Em um total de 125 acidentes estudados, as CIPAs concluíram que 70,4\% deles foram devidos a "atos inseguros" cometidos pelos operários. Das causas diagnosticadas, o fator “descuido, negligência, desatenção e exposição desnecessária ao perigo" somou 37,77\%; “operação incorreta", 15,38\%; "não uso de EPI", 9,09\%, todos fatores ligados ao indivíduo. Por outro lado, o fator "defeito de equipamento, instalação ou ferramenta" (ligados às condições físicas do ambiente de trabalho) correspondeu a 8,39\% do total. Coerentemente com esse modo de explicar os acidentes, as propostas de correção apresentadas pelas três empresas tinham o trabalhador como principal alvo de intervenção: das propostas, $72,9 \%$ referiam-se a

\footnotetext{
${ }^{4}$ CIPAs são comissões, impostas e regulamentadas pela Norma Regulamentadora $n^{\circ} 5$ da Consolidação das Leis Trabalhistas (CLT). São formadas por trabalhadores da própria empresa, dos quais metade é indicada pela direção e metade eleita anualmente pelos trabalhadores. O presidente da comissão é sempre indicado e o vice-presidente, eleito. A CIPA é auxiliada em suas atribuições por engenheiros, médicos e técnicos de segurança da empresa.

5 EPI é a sigla para "equipamento de proteção individual", como botas, luvas, óculos, máscaras, protetores auriculares, etc.
} 
"conscientizar, orientar, insistir em maior atenção disciplinar", "insistir no uso de EPI" e "melhorar treinamento na tarefa", contra 22,2\% referentes a "melhorar equipamento, mudar processo, inspecionar periodicamente, eliminar condições inseguras, melhorar sinalização".

Os autores citados até aqui apontam para a construção de uma "visão estritamente psicológica do mundo", a qual inclui explicações para o acidente de trabalho que acentuam demasiadamente a importância de fatores individuais e terminam, assim, por responsabilizar os próprios trabalhadores pelos infortúnios de que são vítimas. Suas conclusões sugerem que essas formas de compreender os acidentes estão muito presentes em nosso meio social, de modo que não se tratam de produtos descontextualizados das práticas dos especialistas que as difundem, mas de elaborações coletivas a partir de elementos presentes na cultura e, também, em sua formação profissional.

Cohn \& cols. (1985) apontam os modos pelos quais essas concepções, calcadas principalmente no conceito de "ato inseguro", chegam aos trabalhadores e contribuem para construir a percepção que têm dos acidentes e para incutir-lhes uma "consciência culposa":

Esta concepção fundamenta todo o roteiro do repasse da mensagem contida nas campanhas e normas de segurança do trabalho [...] É essa representação que os organismos oficiais passam para a consciência dos trabalhadores: o trabalhador como principal responsável pelo acidente e, portanto, portador de uma consciência culposa [p.149].

No entanto, reconhecem que a assimilação, em suas palavras, da "verdade estabelecida" sobre o acidente de trabalho pelos trabalhadores não é total, mas afirmam que, embora em diversos depoimentos colhidos existissem restrições relativas às condições de trabalho e sua organização, o mecanismo de personalização da responsabilidade pelo acidente prevalecia.

Santos (1991) conclui existir, como base nesses achados e em de outros autores, uma ambigüidade nas formas de percepção que os trabalhadores têm dos acidentes de trabalho:

Essa consciência se constrói a partir da ambigüidade que permeia a percepção que o trabalhador tem sobre as causas do acidente. Assim é que, nos depoimentos recolhidos pelos autores citados em entrevistas com trabalhadores acidentados, estes dividem-se entre a autoresponsabilização e a atribuição do acidente à existência de condições inseguras. A divulgação das normas de segurança, dirigida primordialmente ao trabalhador, faz com que este reconheça que, muitas vezes, descuidou-se daquelas. Ao mesmo tempo, sabe que o "descuido" deve-se ao fato de ter obedecido a ordens superiores ou a imperativos da produção. A autonomia que lhe é falsamente atribuída - como, por exemplo, a de recusar trabalho em condições perigosas e/ou com equipamentos de proteção individual danificados e inadequados etc. - ajuda a estabelecer uma visão equivocada e confusa em relação às causas do acidente [p. 165].

Tendo em vista as implicações da presença dessas formas de explicação na compreensão contemporânea dos acidentes para as respostas sociais adotadas para enfrentá-los e a existência 
de poucos estudos específicos a respeito, considerou-se importante investigar suas origens, seu funcionamento e seu poder de convencimento face a outras formas de explicação.

Para tanto, optou-se pela investigação de práticas discursivas cotidianas voltadas para os acidentes de trabalho. Considerou-se adequada para esse fim a realização de estudo de caso - em uma empresa metalúrgica de grande porte - através do qual pudessem ser analisadas as práticas, os discursos e o funcionamento institucional da empresa, no que diz respeito aos acidentes de trabalho, tendo-se como pano de fundo os discursos construídos por especialistas e difundidos em nosso meio social.

Assim, em síntese, o objetivo principal deste estudo foi analisar as formas pelas quais os acidentes de trabalho são construídos discursivamente por trabalhadores em seu cotidiano, dando ênfase às influências que as concepções estritamente psicológicas - produzidas no campo científico - tiveram sobre esses processos semânticos. Procurou-se, mais especificamente: analisar as condições de produção dos discursos por meio da descrição das concepções acidentológicas presentes nos meios especializados, da identificação da presença das idéias psicológicas e da descrição do contexto institucional da empresa estudada; analisar as práticas discursivas de trabalhadores voltadas aos acidentes de trabalho, destacando-se a relação dos discursos com os diversos contextos em que se inserem, seus aspectos de construção de sentido, sua polissemia e seus aspectos retóricos; analisar as bases discursivas sobre as quais as idéias estritamente psicológicas se sustentam, investigando seus argumentos, as rupturas e formas de resistências com que se confrontam.

Antes de prosseguir, contudo, um último esclarecimento.

\subsection{Individualismo, psicologismo e culpabilização}

Algumas distinções devem ser feitas para que não permaneçam dúvidas a respeito do problema de pesquisa definido. Elas referem-se às explicações para os acidentes que definimos indistintamente como sendo baseadas em fatores individuais ou fatores psicológicos, que por sua vez teriam como conseqüência a atribuição de culpa aos acidentados pelos seus infortúnios.

Certamente, os chamados "fatores individuais" são mais abrangentes que aqueles denominados "fatores psicológicos". Os primeiros agrupam os fatores ligados à pessoa, incluindo suas características biológicas, fisiológicas e psicológicas. Entretanto, no campo da acidentologia, dentre os fatores individuais, os que mais se sobressaem são aqueles de ordem 
psicológica (fatores cognitivos, sensoriais, psicomotores, emocionais). Assim, tomou-se aqui a liberdade de não fazer a distinção precisa entre os dois termos.

Por outro lado, corria-se o risco de, classificando certos fatores como "psicológicos" e associando-os à idéia de indivíduo, sugerir que todos os fenômenos psicológicos seriam de ordem individual, o que é desmentido pelos estudos feitos por muitas correntes da psicologia social, sendo desnecessário citar exemplos. Ora, não é a psicologia em si que se condena aqui, mas o uso comumente feito de suas idéias, que reduz todos os fenômenos humanos a manifestações da mente individual e que abstrai o indivíduo de seu contexto. Assim, optou-se por nomear tais explicações, não como "psicológicas", mas como "psicologizantes" ou “estritamente psicológicas", isto é, aquele tipo de explicação que reduz a complexidade da existência humana a um simulacro psicológico, o qual, por sua vez, exporta sua "lógica" para a compreensão de diversos aspectos de nossas vidas. ${ }^{6}$

Seja lá como for, esse olhar psicologizante constrói uma realidade na qual os problemas sociais seriam supostamente sanados por meio de intervenções sobre aspectos psíquicos ou individuais. Diversas são as conseqüências dessa construção para os nossos modos de vida, uma delas é a atribuição de responsabilidade aos indivíduos pelos problemas que os acometem, por isso a definição como explicações "culpabilizantes".

Feita a exposição do problema de pesquisa e os devidos esclarecimentos, passa-se à apresentação do quadro teórico a partir do qual se delimitou o acidente de trabalho como objeto de investigação.

\footnotetext{
${ }^{6}$ Entretanto, há que se pensar se o projeto da psicologia como um todo não estaria condenado pelas mesmas razões e se a psicologia social deveria apresentar-se como mais um ramo da psicologia ou como um alternativa a ela, mas discutir isso não é nosso objetivo no momento.
} 


\section{O ACIDENTE DE TRABALHO COMO CONSTRUÇÃO SOCIAL}

Os acidentes de trabalho são acontecimentos que se impõem de modo violento aos trabalhadores em seu cotidiano. Esses acontecimentos são compreendidos aqui como frutos de uma dupla construção.

Por um lado, os acidentes de trabalho têm relação com as formas concretas assumidas pelos processos de trabalho no interior dos quais foram gerados. Os processos de trabalho - isto é, os procedimentos e técnicas pelos quais os bens são produzidos - são, por sua vez, determinados pelo processo de produção, isto é, a forma como são organizados os modos pelos quais as pessoas, em sociedade, produzem suas condições de existência. Um dedo amputado não é apenas o resultado imediato do contato entre corpo e máquina. Esse encontro lesivo tem uma história. Há razões para que o trabalhador esteja operando a máquina, bem como para que essa máquina exista e tenha determinadas características. Ora, o trabalhador vende sua força de trabalho e sua ação acrescenta valor à matéria-prima transformada com o auxílio da máquina, a qual, por sua vez - da mesma forma como os bens por ela produzidos - é um artefato humano.

Assim, tanto as relações entre o trabalhador e o empresário, que compra sua força de trabalho, quanto as relações desses com os instrumentos e a própria existência desses instrumentos concorrem para a produção do acidente. As máquinas não estão lá como fato inevitável, pois sua presença deriva de contingências sociais, assim como o seu encontro com os trabalhadores que as operam e aceitam operá-las.

Por outro lado, esses acontecimentos irruptivos - que emergem como produtos das relações sociais e dos artefatos produzidos no interior dessas relações - são, ao mesmo tempo, objeto de interpretação das pessoas e alvo de suas práticas. Isto é, a fim de dar conta desses fenômenos, eles são integrados a sistemas semânticos e a eles são dirigidas respostas sociais. Certamente, essas formas de compreensão do mundo não são construídas de modo harmônico, mas são, parafraseando Grimberg (1988), o resultado conflituoso de práticas sociais de hegemonia, subordinação e questionamento.

Vale ressaltar que esse dois processos não se manifestam de maneira isolada. Pelo contrário, a produção do mundo social e sua interpretação, pelas comunidades humanas que o produzem, acontecem de modo imbricado. Não se pode falar então de dois momentos distintos, um no qual o mundo é produzido e outro em que é interpretado. Ao mesmo tempo em que o mundo é produzido nas relações sociais, ele é interpretado e esta interpretação influencia a sua 
produção. No entanto, analiticamente podemos separá-los para as finalidades da exposição a seguir.

\subsection{O acidente de trabalho como produto da ação humana sobre o mundo}

Desde a década de 60, especialmente na América Latina, vem sendo construído no campo das ciências da saúde, um novo marco referencial teórico de compreensão do adoecer humano. Essas novas idéias têm procurado superar o modelo biomédico dominante, que conceitua a saúde e a doença como fenômenos individuais, estritamente biológicos e a-históricos.

O novo modelo compreende a saúde-doença como um processo determinado socialmente e que se manifesta de forma diversa entre as diferentes classes sociais (Laurell, 1982). Dentro dessa perspectiva, o modo de produção, os diversos modos de inserção no processo produtivo, os "modos de levar a vida" e as relações sociais produzidas nesse contexto são elementos fundamentais para o seu entendimento.

Os acidentes de trabalho, vistos dessa perspectiva, seriam o resultado de condições materiais socialmente determinadas pelas imposições do sistema de produção e pela correlação de forças entre diferentes grupos sociais. Segundo a Organização Panamericana de Saúde (apud Freitas \& cols., 1985),

[a] ...situação de trabalho seria expressão da estrutura social e econômica muito mais do que expressão de "micro ambientes" - e guardaria estreitas relações com a "posição" que o trabalho tenha adquirido na estrutura de cada sociedade concreta [p. 5].

Com base nessa conceituação, Freitas \& cols. (1985) concluem que a melhoria efetiva das condições de trabalho dependeria, na verdade, mais da correlação de forças no campo político e da capacidade reivindicatória dos trabalhadores do que de soluções exclusivamente técnicas, pois a implantação destas últimas seria determinada pelas primeiras.

Dwyer (1989), partindo de outro referencial teórico, chega a proposições semelhantes em relação à produção social das condições concretas de trabalho a que é submetido o operariado fabril:

A antropologia social ensina que a decisão de trabalhar ou não uma substância, ferramenta etc., só pode ser tomada socialmente, dado que todo trabalho é feito de elementos físicos e intelectuais que não podem ser separados de seu contexto social. A idéia de que uma pessoa trabalhe a natureza ou máquinas socialmente neutras e independentes de qualquer relação social é falsa. A pessoa só trabalha as relações sociais transformadas. A aplicação do conhecimento e da habilidade manual à natureza, às ferramentas etc., não pode ter início sem que sejam apreendidas e concebidas socialmente. Essas "coisas" são, portanto, "relações 
sociais transformadas em coisas". Em qualquer ponto do tempo e do espaço elas, e a forma como são concebidas e apreendidas, são o produto do que Touraine chama "a ação da sociedade sobre si mesma". A essas "coisas", que são trabalhadas pelos que agem dentro de um sistema de ação histórico, chamaremos relações sociais transformadas... [p. 25].

Assim, as máquinas, as ferramentas, as substâncias químicas, a divisão e organização do trabalho e, até mesmo, a decisão de produzir ou não determinado produto, são artefatos sociais, frutos da negociação entre grupos sociais. É por isso que a degradação do meio ambiente, os acidentes e as doenças do trabalho não são a conseqüência inevitável do desenvolvimento industrial, supostamente necessário para a satisfação de necessidades humanas fundamentais.

As máquinas que picotam dedos e mãos, o trabalho repetitivo que incapacita braços, as condições insalubres que ceifam os anos de vida dos trabalhadores, o trabalho sem sentido que os enlouquece não estão nas fábricas simplesmente porque necessitamos de carros, carrinhos de supermercado ou quinquilharias de matéria plástica ou, ainda, porque são o único meio possível de produzir esses mesmos bens. Estão lá porque - por meio de um regime baseado em fome, força e ideologia - são impostos aos trabalhadores.

Entretanto, a aceitação dessas condições não é passiva: a história das lutas operárias demonstra a existência de um confronto, no decorrer do qual a definição do "risco aceitável" modifica-se a cada momento, a depender de quem esteja em vantagem, e obriga a transformação das condições concretas de trabalho.

Há limitações nesse tipo de pensamento, já que muitos autores questionam a centralidade da categoria trabalho para a compreensão da sociedade contemporânea e a importância do proletariado como sujeito histórico, na medida em que a existência de diversos grupos sociais na atualidade faz parecer simplista a divisão entre proletários e capitalistas (Offe, 1994). Entretanto, embora possam não ser a chave para a compreensão da sociedade contemporânea como um todo, as reflexões sobre as relações de produção permanecem válidas para o entendimento dos eventos do interior das indústrias ou que dizem respeito especificamente ao operariado fabril.

Mas não é apenas nesse sentido que os acidentes de trabalho são um produto social. Saindo do plano ontológico para o epistemológico, podemos falar de uma outra forma de produção social do acidente: a sua construção como objeto da compreensão humana. Sem cairmos em um dualismo que faz distinção entre mundo objetivo e mundo social (ou intersubjetivo) - o que nos arremessaria em direção aos impasses de uma filosofia representacionista do conhecimento - podemos afirmar que, como todos os fenômeno do mundo, o acidente de trabalho é apreendido pelas pessoas através de sistemas de significação; mais do que isso, os acontecimentos desse mundo passam a habitar a vida das pessoas quando adentram a arena semântica - não se pode negar que eles se imponham às pessoas, é claro, mas a forma que 
vão tomar e o significado que vão ter, dependem da maneira pela qual são interpretados pelos indivíduos em suas relações. O acidente, que se impõe de modo irruptivo, ao ser destacado e delimitado como algo não indiferenciado de outros acontecimentos, é inserido no mundo vivido (que é o mundo por excelência das pessoas) e é aí que se constitui como algo que pode ser pensado, por meio dos valores a ele associados e das concepções que tentam dar conta de sua natureza e de suas causas.

Ao mesmo tempo, essas concepções concretizam-se em práticas sociais. Tais práticas que se diferenciam em função das concepções ou teorias de que são, em certa medida, inseparáveis - interferem na produção concreta dos acidentes. Em outras palavras, não se pretende apenas dizer que o acidente será "visto" de outra maneira, mas que ele vai efetivamente "acontecer" de forma diferente - embora seja arriscado fazer tais asserções no momento em que se pretende adentrar em território construcionista (esclarecimentos a esse respeito são feitos a seguir), sua afirmação é necessária para que não se perca de vista o compromisso com a transformação social. As explicações para os acidentes determinam as formas de prevenção adotadas por diferentes atores sociais. Assim, por exemplo, explicações fatalistas conduziriam à impotência ou ao conformismo; explicações psicologizantes clamariam por intervenções sobre o comportamento dos indivíduos; explicações ambientalistas confeririam validade ao apelo de modificação de máquinas, equipamentos e condições de trabalho. A opção por essas explicações está submetida a condicionantes históricos e contextuais que viabilizam sua aceitação e efetivação em ações concretas.

Assim, discutiu-se até aqui duas dimensões da construção social dos acidentes de trabalho. Ambas também são apontadas por Grimberg (1988), que as sintetiza da seguinte maneira:

Esse ponto de partida faz necessário distinguir analiticamente duas dimensões: as condições estruturais de produção dos processos de saúde-doença e as condições de representação e ação social e institucional dos mesmos. Isso é propor que a saúde e a doença não só são [1] emergentes estruturais das condições de trabalho e de vida de uma formação social, mas também que [2] constituem, ao mesmo tempo, uma construção teórico-prática social e historicamente produzida, resultante de diferentes práticas sociais (de hegemonia, subordinação e questionamento). Considerada nessa dimensão, a saúde-doença aparece como um processo de construção social no qual se vão constituindo modos de representação, assim como respostas sociais e institucionais. Isso supõe então, primeiro, reconhecer que o mesmo processo implica, tanto a configuração das categorias conceituais e os recursos práticos da teoria e da prática médica, como dos modos de percepção-representação e as práticas dos distintos setores de uma sociedade. Segundo, definir o caráter das relações sociais nas quais essa construção sustenta-se [p. 34, itálicos nossos].

Sem perder de vista a tensão entre esses processos constitutivos da realidade social, optou-se pela investigação da segunda dimensão apontada acima: a construção das categorias 
conceituais, dos modos de percepção e das práticas voltadas para os acidentes de trabalho. Esse processo diz respeito à construção de sistemas de significação através dos quais as pessoas dão sentido ao mundo.

\subsection{O acidente de trabalho como construção discursiva}

A postura epistemológica defendida aqui recusa tanto o realismo ingênuo, que acredita em uma relação imediata e invariante com um mundo que só precisa ser descoberto, quanto o subjetivismo solipsista, que atribui a capacidade de conhecer às propriedades da mente individual. Conhecer o mundo é, na perspectiva proposta a seguir, um empreendimento coletivo por meio do qual as pessoas, no intercurso de relações sociais historicamente localizadas, constroem os termos sob os quais os objetos e eventos à sua volta são compreendidos, conferindo-lhes sentido.

Isso significa que as formas pelas quais as pessoas compreendem seu mundo também podem ser entendidas como artefatos sociais. Todas as coisas, com as quais se defrontam os indivíduos em suas vidas, só são reconhecidas enquanto tais por estarem inseridas em sistemas semânticos compartilhados por uma sociedade. Isso não é, de modo algum, o mesmo que afirmar a distinção entre o objeto e sua representação - o que nos levaria à dicotomia cartesiana e aos impasses do empirismo, que reduz o conhecimento ao objeto, ou do idealismo, que o reduz à sua representação - mas justamente chamar a atenção para o caráter inseparavelmente mundano e intersubjetivo do "real". Nesse sentido, podemos tomar emprestadas as palavras de Chaui (1990), que afirma:

Não se trata de supor que há, de um lado, a "coisa" física ou material e, de outro, a "coisa" como idéia ou significação. Não há, de um lado, a coisa em-si e, de outro, a coisa para-nós, mas entrelaçamentos do físico-material e da significação, a unidade de um ser e de seu sentido, fazendo com que aquilo que chamamos "coisa" seja sempre um campo significativo [...] O que dissemos sobre a montanha, podemos também dizer a respeito de todos os entes reais. São formas de nossas relações com a natureza mediadas por nossas relações sociais, são seres culturais, campos de significação variados no tempo e no espaço, dependentes de nossa sociedade... [...] Isto, porém, não implica em afirmar o oposto, isto é, se o real não é constituído de coisas, então será constituído por idéias ou por nossas representações das coisas. Se fizéssemos tal afirmação, estaríamos na ideologia em estado puro, pois para esta última a realidade é constituída por idéias das quais as coisas seriam uma espécie de receptáculo ou de encarnação provisória [p. 18].

Dito de outra forma, as coisas do mundo apenas tornam-se algo para nós quando transformadas em objetos sociais. Essa proposição fica clara quando Wagner (1996) afirma que 
Em um fictício campo não-social, os objetos e as coisas são apenas alguma coisa no mundo [...] No campo social da representação e da construção eles se tornam "objetos" específicos quando com eles se interage ou deles se fala [p 108].

Essa constituição ${ }^{7}$ de "objetos" do mundo social, segundo Wagner, dá-se por meio daquilo que denomina como eventos constitutivos:

"Um evento constitutivo é um evento no curso do qual alguma coisa no mundo é nomeada, equipada com atributos e valores e integrada a um mundo socialmente significativo" [p. 110]

Figura A: A possibilidade de múltiplas realidades dos objetos como presentificação de "alguma coisa no mundo"

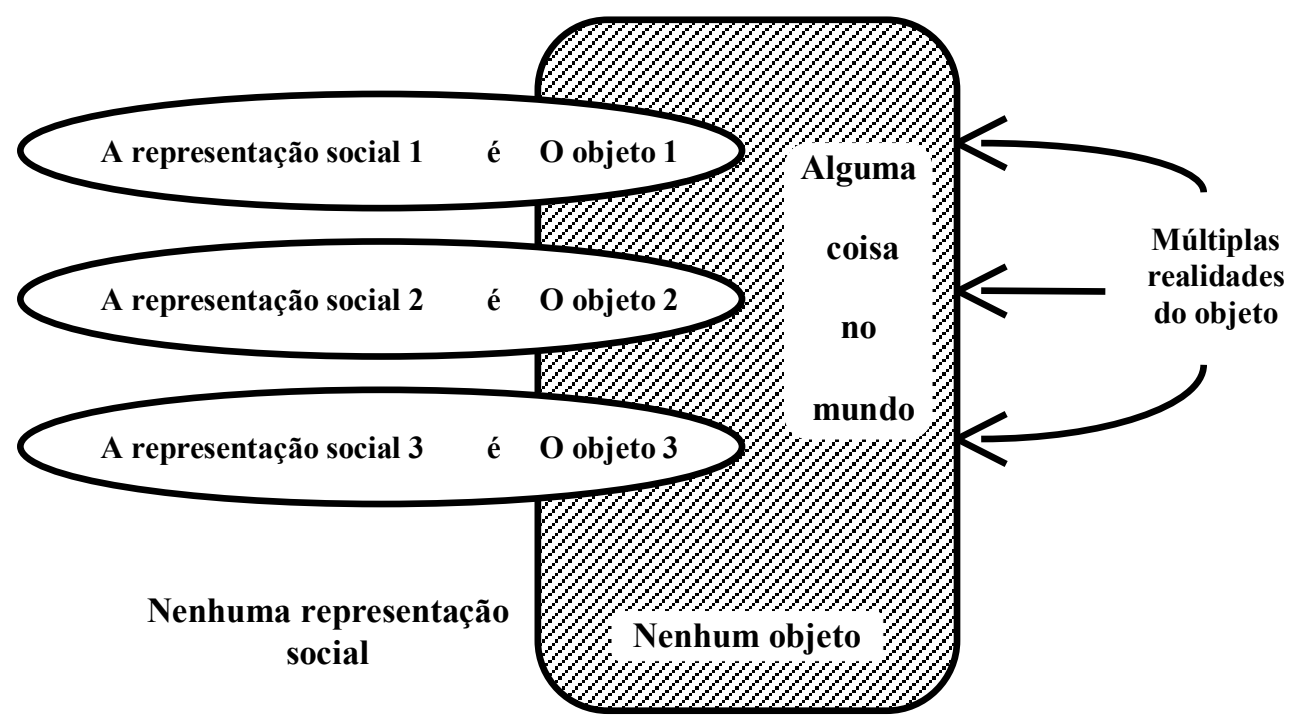

Fonte: Adaptado de Wagner, 1996: p. 109.

A noção de "alguma coisa no mundo" que é transformada em objetos sociais específicos (ver figura a, acima) por meio da ação conjunta e do discurso é muito elucidativa, pois nos afasta, tanto da crença na existência prévia e imutável dos objetos no mundo, quanto da subordinação total das coisas às idéias ou representações, permitindo assim contornar o problema filosófico da existência de duas naturezas estanques e intangíveis.

É partindo da tentativa de superação dessa dicotomia (Gergen, 1985b), representada no pensamento filosófico pelos paradigmas empirista e idealista, e da busca de compreensão das formas pelas quais damos sentido ao mundo, que emerge um novo paradigma, o qual propõe ser o conhecimento uma produção intersubjetiva. Compartilhando essas preocupações, encontram-se diversas formulações teóricas reunidas sob a égide do construcionismo social (Gergen, 1985a, 1989; Ibáñez, 1993; Shotter, 1992; Stam, 1990).

\footnotetext{
${ }^{7}$ Ibáñez (1993), por sua vez, dá a esse processo o nome de "práticas de objetivação", isto é, os objetos do mundo são "objetivações que resultam de nossas características, de nossas convenções e de nossas práticas" (p. 112).
} 
Desde suas primeiras formulações, Gergen (1985a) define o campo de interesse do construcionismo social como sendo o de compreender os processos intersubjetivos de "dar sentido" ao mundo:

A indagação construcionista social está interessada principalmente na investigação dos processos pelos quais as pessoas descrevem, explicam ou de outra maneira compreendem o mundo em que vivem (incluindo elas mesmas). [p. 266].

No construcionismo social, o interesse pelo conhecimento socialmente produzido levanos a mudar o foco de investigação da psicologia social. Abandona-se o interesse pelo desvelamento de processos abrigados pela mente individual e volta-se para a compreensão das ações e práticas sociais e, principalmente, dos sistemas de significação que dão sentido ao mundo. Essa mudança é vital para uma psicologia social que se pretenda realmente social, pois seus conceitos e unidades de análise devem refletir os pressupostos que adota, isto é, eles devem intrinsecamente trazer a superação da dicotomia cartesiana, buscando objetos que integrem aquilo que foi separado.

Embora se pretenda elucidar os processos de significação através dos discursos, esses não são encarados como entidades separadas das ações e das práticas sociais. Por um lado, as ações e práticas são elas próprias permeadas por significados. Por outro, para além de sua função referencial - denotando coisas, eventos ou estados - a linguagem (seja ela verbal, não-verbal ou qualquer outro tipo de convenção semântica) possui uma função performática, isto é, os discursos executam atos de fala (Potter \& Wetherell, 1987). Isso significa que quando falamos também estamos realizando ações. Quando um trabalhador diz que os acidentes "não são provocados", além de expressar um modo de dar sentido ao fenômeno, ele está defendendo-se da conotação de dolo que o uso dessa explicação pode possuir. Quando dizemos "bom dia" a alguém, em um encontro formal, mais do que estarmos nos referindo às características daquele dia, estamos realizando um tipo de ação prevista em um roteiro socialmente compartilhado. A inseparabilidade entre discurso e ação também é apontada por Wagner (1994), que afirma a não existência, entre representações sociais e comportamentos, de relações causais e propõe a conceitualização das representações sociais como "unidades integrais de crenças e ações" (p. 243).

A respeito do papel da linguagem na constituição das formas de percepção da realidade, uma pequena observação deve ser feita. Muitas vezes, como aponta Ibáñez (1993), objeções são levantadas contra o construcionismo social sugerindo que suas proposições reduziriam o mundo a uma entidade lingüística. Ademais tudo o que já se disse acima a respeito da constituição dos objetos sociais - que esclarece a inseparabilidade entre as coisas do mundo, seus significados e 
nossos modos de apreendê-las - Ibáñez apresenta de forma clara sua posição em relação à “acusação de que o construcionismo tenha caído na falácia do reducionismo lingüístico e, portanto, do 'idealismo"”. O autor afirma:

Não é assim, em primeiro lugar, porque quando se comete uma falácia é precisamente quando se confunde o plano epistemológico com o plano ontológico e quando se confundem as condições de possibilidade de um fenômeno com o próprio fenômeno. Aqueles que acusam o construcionismo de reducionismo lingüístico cometem, eles mesmos, a falácia de confundir a afirmação segundo a qual "algo" adquire seu status de objeto real mediante um processo de construção lingüístico-conceitual com a afirmação de que, portanto, esse objeto é de natureza lingüístico-conceitual. Dizer que a linguagem é "formadora" da realidade não significa, muito menos ainda, que a realidade seja de natureza lingüística: é como se disséssemos que, porque um edifício deve sua existência às técnicas daqueles que o fazem existir, esse edifício portanto consistiria exclusivamente de um emaranhado de saberes técnicos [...] Em segundo lugar, também se comete uma tremenda falácia quando se esquece que nossa linguagem não é uma abstração nascida de nossos caprichos, mas que está "motivada", no sentido que Saussure dá a esse termo, por nossas características, nossa história e nosso modo de estar no mundo. Isto significa que nossa linguagem está submetida a um conjunto de constrições que não permitem gerar a partir dela qualquer realidade e modificá-la à vontade [p. 118].

A linguagem, no modo como é compreendida aqui, envolve pelo menos dois aspectos cruciais, como vistos acima, que vão para além da sua função de representar realidades "internas" ou "externas". Primeiro, seu caráter constitutivo da realidade, expresso na integração das "coisas do mundo" a sistemas semânticos. Segundo, seu caráter de ação social, na medida em que é utilizada como ferramenta ou instrumento que dá forma ou sustenta determinados tipos de relações entre pessoas (ver Shotter, 1992).

Certamente, a constituição discursiva de objetos sociais não se dá em um vácuo semântico. Muito pelo contrário, a atribuição de significado às coisas é feita a partir de sua integração a sistemas semânticos que preexistem ao momento da interação. Afinal, habitamos um mundo que é repleto de significados e de objetos sociais que já estavam lá antes de chegarmos. Desse modo, é a partir dos elementos do imaginário social que esses objetos são constituídos e reconstruídos; as possibilidades de formas que podem assumir dependem das condições sociais e históricas que os produzem. Wagner (1996) fala da importância dos conteúdos culturais estáveis para os estudos que partem do referencial da análise de discursos, afirmando o seguinte:

A pesquisa sobre discursos leva em conta eventos lingüísticos constitutivos específicos, os quais apenas fazem sentido contra o pano de fundo do ambiente mais estável dos significados importantes da fala e do comportamento abrangidos pelas representações sociais [p. 113].

Assim, a compreensão dos discursos e das ações deve levar em conta a relação entre as permanências do imaginário social e as características imanentes dos processos cotidianos de 
significação. Nesse sentido, Spink (1996a) fala dos diferentes contextos em que se manifestam os conhecimentos socialmente produzidos e as perspectivas temporais que os determinam, fazendo com que assumam diferentes formas e características, a depender da escala em que são estudados. Os contextos e suas perspectivas temporais serão esclarecidos no próximo capítulo.

No cotidiano, esse processo de construção da realidade social acontece incessantemente no interior de práticas discursivas, que podem ser definidas como "os modos pelos quais as pessoas ativamente produzem realidades sociais e psicológicas" (Davies \& Harré, 1990: p. 45). Definidos dessa maneira, ações e discursos passam a compor uma mesma unidade de análise.

Os conteúdos do imaginário social não aparecem nas práticas discursivas de maneira inequívoca. Pelo contrário, o falar e o fazer cotidianos são marcados pela contradição e pela ambigüidade, características que se manifestam no uso sobreposto de padrões recorrentes de compreensão da realidade, os quais são denominados por Potter \& Wetherell (1987) como repertórios interpretativos. Segundo esses autores:

Os repertórios interpretativos são sistemas de uso recorrente utilizados para caracterizar e avaliar ações, eventos e outros fenômenos. Um repertório [...] é constituído através de uma série de termos que são utilizados em construções estilísticas e gramaticais particulares. Freqüentemente um repertório será organizado em torno de metáforas e figuras de linguagem específicas (os tropos)... [p. 149].

Assim, a interpretação e a construção de sentido conferem aos discursos características polissêmicas (Spink, 1996a), isto é, um mesmo objeto social adquire diferentes significados no intercurso da interação, o que também corresponde às mudanças entre os diferentes "registros de vozes", para usar o referencial bakhtiniano (Volochínov, 1992). Portanto, “a linguagem não pode ser vista como contendo uma simples concepção de mundo" (Billig, 1991). Como propõe Gramsci (apud Billig, 1991), o pensamento comum carrega várias concepções de mundo e sedimenta concepções de várias épocas. Com efeito, a polissemia é a principal característica das práticas discursivas, que permite, dentre outras coisas, a manifestação de fenômenos semânticos como as contradições, os deslizamentos ou deslocamentos e as rupturas de significados.

A tessitura semântica produzida pelas diferentes concepções presentificadas nas práticas discursivas confere a essas a característica de um diálogo, pois toda enunciação é formulada como resposta a outras enunciações e sempre pressupõe um interlocutor, mesmo que seja, por exemplo, uma ordem despótica. Esse dialogismo deve ser entendido aqui como um processo social que permeia tanto as práticas discursivas, quanto o pensamento.

Esse diálogo acontece entre posições, não apenas diferentes, mas opostas. Trata-se de um diálogo argumentativo, no qual os argumentos a favor de uma determinada posição levam em conta a posição contrária. Isso faz com que a compreensão do sentido de qualquer afirmação só 
aconteça quando levamos em conta as afirmações que se pretende combater, o que liga de maneira indissociável o discurso ao contexto e revela seu caráter retórico (Billig, 1987, 1991).

No caso dos acidentes de trabalho, por exemplo, a afirmação de uma posição, mais do que expressar uma opinião, situa o enunciador em uma controvérsia que tem raízes que ultrapassam o contexto imediato da interação. Isso significa que os próprios significados da cultura são de natureza conflituosa.

Essa idéia permanece verdadeira mesmo em situações em que determinadas posições predominam sobre outras, como é o caso, por exemplo, do consenso produzido pela propaganda. A esse respeito, Billig \& cols. (1988) afirmam:

Se há temas opostos, isso não significa que a oposição é igualmente balanceada. Um tema pode ser mais dominante em discursos particulares. Esses termos podem ser aqueles tomados como certos, cujas formas passam desapercebidas [...] A presença de temas contrários é revelada pelo uso de qualificações. A expressão desqualificada de um tema parece trazer à tona uma contra-qualificação a favor do tema oposto. Há uma tensão no discurso que pode fazer com que mesmo o monólogo tome a forma de argumentação e o argumento ocorra mesmo quando todos os participantes compartilhem temas contrários similares [p. 144].

Ainda, não é apenas nas situações dramáticas que a argumentação revela-se como um aspecto importante. Como aponta Billig (1991), ela difunde-se através de toda a vida social.

As máximas presentes no senso comum são um bom exemplo do que estamos falando. Vejamos dois ditados existentes em nossa língua. Temos, por um lado, aquele que diz que "nem tudo que reluz é ouro". Esse ditado é usado quando se pretende sugerir a um interlocutor que uma pequena evidência pode não significar algo importante. Por outro lado, podemos ser aconselhados por alguém que "onde há fumaça, há fogo", o que aponta para o fato de que uma pequena evidência pode querer dizer muito. Ora - da mesma forma como em "seguro morreu de velho" e "quem não arrisca, não petisca" - temos duas máximas igualmente populares que orientam nossas ações em direções completamente opostas!

Essas máximas expressam alguns dos diversos dilemas que vivem as pessoas em seu diaa-dia, isto é, situações intrincadas em que suas ações podem tomar diferentes direções. Também revelam como a decisão mais banal é tomada em um contexto argumentativo.

Os argumentos utilizados nessas situações dilemáticas não estão prontos a priori. Eles são elaborados em função dos diálogos em cursos e dos outros argumentos apresentados pelos

\footnotetext{
${ }^{8}$ Toda a reflexão apresentada a seguir, mesmo quando não são feitas citações, está baseada na psicologia retórica proposta por Billig (1987, 1991; Billig \& cols. 1988).
} 
interlocutores". O que os sistemas semânticos fornecem são as "sementes" para a construção desses argumentos. Assim, os repertórios interpretativos - encarados como um conjunto de significações que habitam o contexto argumentativo e que são amplamente compartilhadas fornecem os lugares-comuns a partir dos quais qualquer argumento é construído (Billig, 1987). Os lugares-comuns, conforme a tradição retórica, são uma metáfora espacial que designa as idéias às quais deve recorrer o orador para convencer sua audiência, em razão da sua grande aceitação. Nesse sentido, a mesma expressão é sinônimo de trivialidade. Shotter (1992) expõe de forma muito clara a relação entre o contexto argumentativo e os lugares-comuns:

Um contexto argumentativo é de fato, portanto, um tipo muito estranho de entidade, pois "contém" meios de falar e escrever, de pensar, sentir, perceber, agir e ponderar que são postos juntos em uma unidade dinâmica, não porque estejam todos fundados no mesmo conjunto de princípios lógicos ou pressupostos - e assim constituindo um sistema - mas porque eles originam-se em e são direcionados para a elaboração ou ulterior especificação de certos "tópicos" ou "lugares-comuns" (topoi) - "lugares de argumentação" que funcionam como fontes "formadoras" para os argumentos de ambos os lados! [p. 16].

Assim, a argumentação pressupõe a existência desses lugares-comuns, aos quais se recorre quando se pretende justificar uma posição no interior de um diálogo. O convencimento de alguém só não se dá dessa maneira quando se recorre à força, momento em que o diálogo já não mais existe. A violência estatal é uma constante nos regimes totalitários, mas é velada nas democracias, o que faz da retórica um instrumento importante de convencimento. Esse exemplo extraído da política remete a um outro aspecto importante dos discursos, que contribui para a inteligibilidade da vida social cotidiana.

Retomando o pensamento de Billig, esse propõe que a construção de uma psicologia retórica envolve - além da aproximação com a tradição retórica - uma compreensão do pensamento social como processo ideológico. Sua proposta é acrescentar à crítica ideológica do senso comum uma dimensão argumentativa, considerando a maneira pela qual grupos dominantes utilizam recursos retóricos para perpetuar o domínio de suas idéias e compreendendo o pensamento social como um contínuo diálogo argumentativo. Segundo o autor (Billig, 1991):

Isso significa estudar o pensamento e a tomada de opinião em seu contexto social. No mínimo, isso supõe a aceitação de que o tempo e o lugar nos quais as pessoas vivem afetam a natureza de seu pensamento. No entanto, há mais um fator - o fator ideológico. Os próprios conteúdos do pensamento cotidiano - as máximas, os valores e as opiniões comuns etc. - são eles mesmos produtos culturais. No pensamento ordinário, as pessoas usam um "senso comum", o qual não foi inventado por elas mesmas mas que tem uma história. Como, desde Marx, os teóricos críticos salientam, o senso comum é uma forma de ideologia. Isto significa que o senso comum não apenas tem uma história mais ampla, mas que também possui funções atuais, as quais estão relacionadas a formas de dominação e poder. Ao usar noções

\footnotetext{
${ }^{9}$ Isso corresponde à constatação de Bakhtin de que todo enunciado é construído pressupondo-se um interlocutor e em resposta a um enunciado anterior.
} 
do senso comum, as pessoas encontraram-se repetindo os pressupostos de seus tempos. Além disso, de acordo com os teóricos que discutem o conceito de ideologia, elas estarão repetindo pressupostos que confirmam os arranjos de poder existentes. Desse modo, a contínua história de dominação flui através do pensamento do senso comum [p. 1].

Esses aspectos da ideologia e a forma como o conceito foi utilizado neste trabalho serão discutidos na seção a seguir.

\subsection{A ideologia como retórica e como modo ou estratégia de dominação}

Sampson (1987), ao apresentar os argumentos para um construcionismo crítico, defrontase com o problema da compatibilidade entre o construcionismo e um certo tipo de crítica social, problema que é apresentado pelo autor da seguinte forma:

Até aqui, minha posição foi basicamente construcionista. Uma visão construcionista crítica dá um passo além. Não estando satisfeitos em fazer a observação de que a individualidade é uma construção social e histórica, nós questionamos agora as funções e a adequação de qualquer produto social particular. Aparentemente, esse último questionamento poderia parecer absurdo. Afinal de contas, se a realidade é socialmente construída, incluindo os critérios pelos quais nós julgamos qualquer construção social, então, a partir de qual posição podemos sustentar nossos julgamentos de qualquer criação social? Isso exigiria uma outra realidade por trás da realidade construída a fim de permitir-nos falar a respeito desses temas. Isso não nos conduziria do paradigma construcionista de volta para um modelo objetivista? [p. 43].

Juntamente com essa última pergunta, à qual Sampson responde negativamente, podemos formular outra: da mesma maneira, um relativismo atroz, que não admite julgamento algum, não nos levaria de volta a um modelo idealista?

As duas perguntas levam a refletir a respeito do papel do construcionismo no debate intelectual contemporâneo. Afinal, qual é o grande valor do construcionismo para a compreensão de nossos modos de vida senão a força com que desnaturaliza realidades tomadas como certas?

Ora, esse é justamente o ponto, pois o construcionismo tem, por essa mesma razão, um caráter inerentemente crítico.

Toda essa discussão tem paralelo com o problema da ideologia e com a possibilidade de utilização desse conceito no interior de uma compreensão construcionista do mundo social. Assim, traduzindo a inquietação de Sampson para esses termos, assume-se uma concepção da realidade como construção social na qual, embora os acontecimentos do mundo imponham-se às pessoas, sua compreensão é sempre mediada por sistemas semânticos que a eles conferem sentido e modelam sua existência. Entretanto, as relações sociais, no interior das quais esses 
processos de significação desenrolam-se, são marcadas pela desigualdade e, como resultado disso, encontram-se mecanismos sociais que favorecem a predominância de determinados significados que contribuem para a manutenção dessas mesmas relações. Assim, chega-se à caracterização do fenômeno ideológico em sua acepção marxiana, isto é, da ideologia como o modo pelo qual as idéias das classes dominantes tornam-se as idéias de uma época (Marx \& Engels, 1993).

O problema do uso desse conceito está na grande confusão em torno de sua definição e, principalmente, na conotação de distorção da realidade que têm algumas de suas variações, o que pressuporia uma verdade última a ser revelada pela análise crítica. Como procuraremos demonstrar, esse segundo problema pode ser contornado, preservando-se o papel de dominação atribuído à ideologia e suspendendo-se as tentativas de verificação de sua falsidade ou veracidade. Quanto ao primeiro problema, ele constitui na verdade a principal razão para a utilização do conceito: sua polissemia e o que revela das diferentes facetas da natureza dos discursos.

Parece ser consenso entre aqueles que se dedicaram a estudar o conceito de ideologia que sua definição é bastante problemática (Billig \& cols., 1988; Guareschi, 1995; Montero, 1989, 1995). Da mesma forma como esses autores, não pretendemos chegar a uma solução para a questão, mas salientar alguns aspectos importantes para a compreensão de nosso objeto de investigação. Destacamos dois aspectos da definição do conceito: o papel do indivíduo na ideologia e a compreensão dessa como modo ou estratégia de dominação.

Billig (Billig, 1987, 1991; Billig \& cols., 1988), ao propor sua psicologia retórica, pretende superar, ao mesmo tempo, a psicologia cognitiva tradicional - que deixa de lado a natureza social dos conteúdos do pensamento - e muitas das teorias da ideologia, que, embora considerem os aspectos históricos da construção das idéias, ignoram o pensamento dos indivíduos ${ }^{10}$ :

Em contraste com os psicólogos cognitivistas, nós enfatizamos a natureza ideológica do pensamento; em contraste com os teóricos da ideologia, nós enfatizamos a natureza pensante da ideologia. Essa ênfase é conseguida salientando-se os aspectos dilemáticos da ideologia e do pensamento em geral [Billig \& cols., 1988: p. 2].

Desse modo, o autor faz sua crítica às definições de ideologia que excluem o papel dos indivíduos na produção de sentido. Essa crítica revela um paradoxo da ideologia, cuja definição tem sido formulada a partir de dois pontos de vista contrastantes; um, enfatizando a imagem da

\footnotetext{
${ }^{10}$ A oposição aqui não é entre indivíduos isolados e sociedade, mas entre os indivíduos em interação e a estrutura social.
} 
pessoa comum com um pensador; outro, concebendo esse pensamento como mera reprodução dos conteúdos ideológicos difundidos pelas classes dominantes. Segundo Billig (1991), esse paradoxo:

...é uma variante de um paradoxo geral da linguagem, pois o uso da linguagem envolve tanto autonomia quanto repetição [...] de um lado, a fala é uma asserção de alguém e, assim, o falante é o mestre do momento. Por outro lado, a fala é uma repetição de sinais [...] A natureza paradoxal do uso da linguagem sugere que as tentativas teóricas de liquidar ou resolver o paradoxo são menos convincentes que explicações que expressam o paradoxo nelas próprias [p. 8].

Billig demonstra que a ideologia não determina a consciência de forma direta e inequívoca, pois o sujeito da ideologia dialoga e argumenta com ela. A sua sugestão é que esse dilema entre autonomia e reprodução deve ser preservado no interior das teorias que tentam dar conta do senso comum, "desse modo, o pesquisador reserva-se o direito, tanto de respeitar o filosofar do senso comum, quanto de criticá-lo" [p. 13]. Assim, a relação entre os sujeitos e a ideologia é concebida como um caminho de mão dupla, isto é, a teoria é construída assumindo a contradição entre agência e estrutura:

A pessoa comum - o "sujeito" da ideologia - não é um cego ingênuo cuja mente foi preenchida por forças externas e que reage impensadamente. O sujeito da ideologia é um ser retórico que pensa e argumenta com a ideologia [Billig, 1991: p. 1].

O mesmo deve ser dito a respeito de todo conhecimento social, pois os diversos atores sociais estão submetidos à ideologia e com ela pensam e argumentam, sejam eles operários ou o cientistas. Afinal, o saber do especialista é da mesma natureza que o saber popular, apesar de ser socialmente atribuído ao primeiro um status de superioridade em relação ao segundo, o que é próprio da ideologia.

Montero (1989), por sua vez, aponta dois padrões básicos assumidos pelas diversas versões do conceito de ideologia na literatura psicológica. Ora o conceito aparece como sinônimo de "visão de mundo", ora como distorção do real ou falsa consciência. A autora afirma que o uso da primeira conotação tem por conseqüência o abandono do aspecto mais importante desse conceito que é o seu papel como forma de dominação social e sugere que seja abandonado, a favor do uso da segunda conotação. Essa última conotação é preconizada por Billig (1991), ao afirmar que:

Uma dimensão de classe pode ser adicionada à crítica da retórica. Pode-se afirmar que, em todas as épocas, a classe dominante possui a retórica dominante e o proprietário dos meios de produção é o proprietário dos meios de persuasão retórica. Essa propriedade capacita a classe dominante a apresentar suas mensagens de forma convincente, não importando sua veracidade ou falsidade. $\mathrm{O}$ argumento parece adequado para um tempo em que orçamentos de propagandas para sopas instantâneas, temas de interesse público e campanhas políticas envolvem o investimento de bilhões de dólares [p. 4]. 
Entretanto, como apontado acima, a idéia de distorção da realidade presente na concepção negativa de ideologia pode levar a supor que, por trás da imagem distorcida, haveria o objeto real e, sendo assim, tal objetivismo seria incompatível com uma posição construcionista. No entanto, a concepção negativa de ideologia pode prescindir desse pressuposto sem que haja incompatibilidade com a perspectiva teórica aqui adotada. Isso levaria à seguinte reformulação: embora não possamos falar de distorção da realidade - já que não temos critérios para julgar tê-la encontrado ou não - podemos deixar a questão da falsidade da ideologia e voltamo-nos para o funcionamento e as conseqüências dos mecanismos sociais que tornam hegemônicas determinadas versões da realidade. Assim, poderíamos afirmar que a compreensão do mundo é mediada por sistemas semânticos e, em muitos casos, o seu uso pode resultar na naturalização, perpetuação e legitimação de determinadas visões de mundo. Nesses casos, encontramos um funcionamento ideológico. Essa perspectiva não considera os sistemas de significados como ideológicos em si, mas, ao analisar suas implicações para nossas vidas, reconhece neles modos ou estratégias de dominação.

Seguindo esse mesmo caminho, Guareschi (1995, p. 52) fala de uma nova aproximação ao estudo da ideologia que não está tão interessada na questão da falsidade ou não de seus conteúdos, mas, sim, nos modos pelos quais as formas simbólicas criam e sustentam relações sociais de dominação, preservando a dimensão crítica do conceito:

Assim, um fenômeno ideológico só é ideológico se ele serve, em circunstâncias específicas, para estabelecer e sustentar relações de dominação. Isso quer dizer que os fenômenos não são ideológicos em si mesmos; não se pode retirar o caráter ideológico dos próprios fenômenos como tais, mas somente quando os situamos em contextos sócio-históricos onde eles passam a estabelecer e sustentar relações de dominação. E a questão de se dizer se essas relações estabelecem ou sustentam relações de dominação só pode ser respondida quando se examina a interação entre sentido e poder em circunstâncias particulares [p. 53] ${ }^{11}$.

Isso é ainda mais importante quando constatamos que a própria psicologia tem contribuído para a construção de significados que são contemporaneamente utilizados para a sustentação do status quo (Prilleltensky, 1994), o que remete ao papel político dessa disciplina (Ibáñez-Gracia, 1993; Martín-Baró, 1983, 1989; Montero, 1990, 1996; Sampson, 1987). Quanto a essa contribuição conservadora da psicologia, podemos retomar as palavras de Sampson (1987), que sugere um outro papel, transformador, a ser assumido pelos psicólogos construcionistas através do desvendamento da origem sócio-histórica das asserções psicológicas:

\footnotetext{
${ }^{11}$ De qualquer modo, não precisaríamos ter ido tão longe. A idéia de distorção da realidade está presente, apesar de toda a problemática discutida acima, em autores construcionistas como lbáñez. Esse autor fala da distorção produzida pela "retórica da verdade científica" (Ibáñez, 1993), que oculta a origem social do conhecimento, fazendo com que se tomem as afirmações dos especialistas como verdades absolutas. Todo o projeto construcionista, incluindo aqui os estudos sobre a construção social das emoções, da memória etc., tem a marca da desnaturalização das coisas do mundo.
} 
Contudo, seria absurdo sustentar que a psicologia é a origem ou a fonte única desse papel social perpetuador. Antes, a psicologia, dentre as outras ciências do comportamento humano, participa da construção da compreensão que os indivíduos têm de si e os ajuda a terem uma visão direta do seu próprio comportamento e das causas deste. A psicologia não cria seus conhecimentos de maneira fictícia, mas ao meramente relatar os achados empíricos que descobre e ao tratar esses achados como se, no entanto, fossem verdades eternas da existência humana mais do que construções sócio-históricas, ela gera o mesmo tipo de conhecimento que contribui na sustentação de práticas e instituições. No mínimo, um psicólogo construcionista poderia mostrar-se transformador ao apontar as raízes sociais e históricas dos "fatos" psicológicos prevalecentes e ao lembrar o papel desses "fatos psicológicos" na manutenção das formas sociais em curso [p. 55].

No que diz respeito aos acidentes de trabalho, nossa intenção foi propor uma interpretação que revelasse as origens e as funções cumpridas por determinadas concepções que, ao responsabilizarem os indivíduos pela sua ocorrência, naturalizam as condições de trabalho e eliminam do horizonte do pensamento as possibilidades de mudanças dessas mesmas condições, cumprindo o papel ideológico de fazer determinadas concepções prevalecerem sobre outras e de legitimá-las. 


\section{A INVESTIGAÇÃO DAS PRÁTICAS DISCURSIVAS}

O objetivo de estudar discursos e práticas cotidianas sobre os acidentes de trabalho poderia ser realizado de diversas formas, cada qual com suas vantagens e limitações - embora, como veremos na próxima seção, diferentes níveis de análise dos conhecimentos sociais requeiram abordagens diversas, sob o risco de mascaramento de características peculiares a cada um deles (Spink, 1996a). Sem entrar ainda no mérito da questão, optou-se aqui pelo estudo de uma empresa-caso e a investigação dos contextos sociais em que se manifestam as práticas discursivas dos trabalhadores dessa empresa. Estudar simultaneamente práticas discursivas e contextos expressa a tentativa de preservar a tensão entre os conteúdos que compõem o imaginário social e impõem-se aos indivíduos, de um lado, e "as forças decorrentes do próprio processo de interação social e as pressões para definir a situação de modo a confirmar e manter as identidades coletivas" (Spink, 1993: p. 5), de outro.

O estudo do contexto é salientado por Spink, que fala de sua importância para a compreensão das representações - ou dos repertórios interpretativos - definindo-o como um "prétexto", isto é, o pano de fundo que antecede e permite a compreensão daquilo que é dito ou feito, o texto:

Como pré-texto, o contexto é o pano de fundo essencial para que o texto propriamente dito $\mathrm{o}$ ato comunicativo onde grassam as representações - possa ser compreendido. Sem conhecimento da estrutura social em que se dá uma determinada comunicação (uma conversa, uma entrevista, um texto escrito) não teríamos elementos para interpretar as representações aí evidenciadas ou mesmo constituídas [Spink, 1993: p. 3].

Definidos por espaços sociais e perspectivas temporais determinadas, os contextos discursivos podem ser separados analiticamente em diferentes níveis. Para a finalidade desta pesquisa, a partir das reflexões de Spink (1993, 1994, 1996a, 1996b), foram delimitados três contextos a serem abrangidos pela investigação.

Primeiro, o contexto do imaginário social, no qual circulam concepções sobre os acidentes de trabalho largamente difundidas através de diversos setores da sociedade. Esse contexto está determinado pela perspectiva temporal que Spink denominou como tempo longo ou histórico, em que se encontram - inscritos na memória social - os conteúdos histórica e culturalmente constituídos. Conforme a autora:

É através dessa escala de tempo que nós podemos apreender a diversidade de repertórios que estão disponíveis, que serão moldados pelas circunstâncias de uma dada sociedade em uma 
época determinada e que constituirão as múltiplas vozes que estão presentes em nossos enunciados [Spink, 1996a: p. 4].

Segundo, o contexto institucional, que se refere às práticas institucionalizadas de prevenção de acidentes e educação de trabalhadores e às disposições adquiridas pela socialização e filiação a organizações - incluídas aqui as construções simbólicas usualmente denominadas de "cultura organizacional" - sendo assim determinado pela perspectiva temporal denominada por Spink como tempo vivido. A fábrica apresenta-se aqui como o contexto mediato da ação em que se contemporizam e é feita a mediação entre as permanências culturais da memória social e os processos cotidianos de significação da realidade dos acidentes de trabalho.

Finalmente, o contexto da interação, em que se manifestam mais claramente as caraterísticas dialógicas dos processos de constituição da realidade social. Esse é o espaço por excelência da polissemia e da construção cotidiana de significado, no qual ecoam os conteúdos extraídos do primeiro contexto e modulados ${ }^{12}$ pelo segundo. Por referir-se às relações imediatas, Spink denominou a perspectiva temporal que determina esse contexto como tempo curto ou da interação. As entrevistas, as conversas informais e os registros de situações cotidianas dizem respeito a esse contexto. Segundo Spink (1996a):

Esse é o momento concreto da vida social vista como inter-ação. Esse é o momento quando o reservatório de referentes ao qual aludiu Jodelet toma forma através de gestos e palavras. Nesse momento específico são ativadas as diversas possibilidades de combinações das vozes originárias da memória social dos tempos histórico e vivido. Como são múltiplas as combinações, encontramo-nos diante da polissemia [p. 5].

Todos os três contextos acima definidos comportam contradições e temas opostos, pois a consciência comum compartilhada não é um sistema unificado e homogêneo de significados (Billig \& cols., 1988), como visto no capítulo anterior. Entretanto, é no contexto argumentativo da interação que essas contradições são vivenciadas como dilemas.

O estudo do primeiro contexto, de escala social, foi feito a partir de revisão da literatura de higiene e segurança no trabalho e de psicologia, buscando-se identificar o pensamento constituído sobre os acidentes de trabalho nos meios especializados. Dentre outras coisas, procurou-se localizar as principais teorias acidentológicas, conhecer as diversas abordagens da psicologia e delimitar o discurso que as "ciências do comportamento" construíram no Brasil sobre os acidentes de trabalho, investigando sua difusão e enraizamento no imaginário social. Embora a delimitação para essa dimensão temporal não tenha voltado mais atrás no passado em

\footnotetext{
12 O conceito de modulação, extraído da música, é muito elucidativo, pois se refere a variações de altura ou de intensidade na emissão de sons ou à passagem de uma mesma melodia para um modo ou tom diferentes (refere-se também a variações na tonalidade de cores). Seu uso tem por objetivo enfatizar que o contexto institucional, ao presentificar conteúdos do imaginário social, não modifica sua essência, mas os adapta ao lugar e ao momento.
} 
busca das origens do individualismo na sociedade ocidental - nem das outras influências culturais que as concepções sobre os acidentes poderiam ter - ela permitiu conhecer os modos pelos quais conteúdos culturais importantes refletem-se em um fenômeno contemporâneo. Quanto aos outros dois contextos, eles foram investigados através do estudo de caso de uma empresa do ramo metalúrgico.

Os textos reunidos em revisão bibliográfica, as anotações em diário de campo sobre o estudo de caso - incluindo relatos de acontecimentos presenciados, filmes assistidos, reuniões e conversas informais - os registros ampliados, as entrevistas transcritas, as cópias de documentos e apostilas constituíram o corpus sobre o qual se realizou a análise proposta adiante. O tratamento dado aos textos de higiene e segurança no trabalho e de psicologia foi assistemático e, em parte, orientado por revisões feitas por outros autores. Os discursos e práticas, obtidos através do estudo de caso, foram analisados sistematicamente, buscando-se a identificação de repertórios interpretativos, padrões de variabilidade e de consistência e a compreensão de seu sentido argumentativo. A interação dos três contextos foi apontada durante toda a análise, procurando-se desse modo compreender como os acidentes são construídos no interior de práticas discursivas e estabelecer relações entre essas práticas e as formas historicamente estáveis e compartilhadas de compreensão do fenômeno.

Sendo os elementos mais importantes do desenho metodológico adotado nesta pesquisa, os detalhes sobre o estudo de caso e as justificativas para o tipo de entrevista utilizada serão apresentados a seguir.

\subsection{Sobre o estudo de caso}

Spink (1995, 1996a), ao partir da distinção feita por Moscovici entre os diferentes níveis em que se manifestam as representações sociais, aponta para as implicações teóricas e metodológicas da escolha entre escalas diferentes de investigação. Assim, os estudos feitos em macroescalas, como da consciência comum de uma sociedade, por estarem interessados na difusão e no compartilhamento coletivo das representações, dão maior ênfase à comunalidade desses conhecimentos e à sua estabilidade (Spink, 1995). Por outro lado, a opção pelo estudo de microescalas - como a interação social e as práticas discursivas - requer modelos teóricos que permitam compreender os processos dialógicos de construção de significado e a polissemia dos discursos (Spink, 1996a).

Da mesma forma, a investigação em microescala solicita métodos que focalizem situações de interação e registrem produções discursivas cotidianas nas quais os referidos 
processos possam ser analisados. Os estudos de caso (Yin, 1989) prestam-se adequadamente a esse objetivo e os resultados que vierem a ser obtidos, no que se refere às formas de compreensão dos acidentes de trabalho, podem muito provavelmente conferir inteligibilidade aos acontecimentos que se desenrolam em outros agrupamentos com características semelhantes ao estudado.

Assim, definiu-se como caso uma empresa metalúrgica na qual seriam estudadas as práticas discursivas de trabalhadores, através da análise do uso de repertórios interpretativos sobre os acidentes de trabalho. Esse recorte - diferente, por exemplo, de uma investigação em um bairro popular no qual seriam entrevistados operários sem levar em consideração o fato de trabalharem no mesmo lugar - permitiu que se estudasse um contexto institucional específico, de modo que a mediação entre as permanências culturais e os processos cotidianos de significação poderia ser analisada com maior facilidade.

A empresa-caso foi escolhida dentre aproximadamente 900 empresas de uma região industrializada da Grande São Paulo ${ }^{13}$. Tendo em vista que aproximadamente $80 \%$ dos trabalhadores metalúrgicos dessa região concentravam-se em cerca de 20 empresas de grande porte, selecionou-se uma delas para estudo, a partir de indicações do sindicato de trabalhadores metalúrgicos da região e com base nos seguintes critérios: deveria ser uma empresa com prevalência e incidência significativas de acidentes, que demandassem práticas estruturadas de prevenção e educação de trabalhadores para a segurança no trabalho; com a finalidade de garantir uma população versada nos repertórios interpretativos locais, a média de tempo de trabalho dos operários na empresa deveria ser superior a 5 anos; seria igualmente importante a existência do consentimento para visitas freqüentes de observação do dia-a-dia de trabalho, conversas com funcionários no chão de fábrica e leitura de documentos - como atas de CIPA, relatórios de acidentes e outros.

As ações e os discursos relacionados aos acidentes de trabalho foram estudados a partir de diferentes fontes de evidências: observações diretas do processo de trabalho, da atuação da equipe de segurança e da CIPA; textos sobre programas de prevenção de acidentes adotados pela empresa, apostilas didáticas, fichas de análise de acidentes e outros documentos; conversas informais com trabalhadores, cipeiros, diretores sindicais de base, supervisores, técnicos de segurança, engenheiro de segurança; entrevistas semi-estruturadas com trabalhadores da produção.

\footnotetext{
${ }^{13}$ Um questionário exploratório, respondido por 38 trabalhadores da região estudada, foi utilizado como primeira aproximação à questão dos acidentes. Embora esses dados não tenham sido integrados à análise, serviram como ilustração e seus detalhes encontram-se no anexo a.
} 
O trabalho de campo foi realizado ao longo de aproximadamente três meses. Todos os acontecimentos - desde a primeira reunião com o sindicato até os bastidores das entrevistas foram registrados em diário de campo. Apontamentos eram feitos no local e posteriormente ampliados com a inclusão de detalhes relembrados e de análises prévias (ligações entre os acontecimentos, relações com os textos estudados e hipóteses de trabalho). Muito tempo foi dedicado a essa atividade, a qual se revelou valioso investimento, pois os discursos colhidos nas conversas informais e os registros das observações permitiram a compreensão global dos conteúdos representacionais da empresa e serviram como complemento e contraponto às entrevistas posteriormente realizadas. Para orientar o trabalho de campo foi elaborado um roteiro para observação e entrevistas. Esse roteiro foi aprimorado no decorrer da investigação e encontra-se no anexo b.

Depois de algumas conversas iniciais com membros da equipe de segurança da empresa durante as quais se obtiveram informações gerais sobre o processo de trabalho e os acidentes ocorridos - percorremos-se os diversos setores em um período de cinco dias. Essas visitas, que foram conduzidas pelos técnicos de segurança do trabalho responsáveis por cada setor, incluíram acompanhamento do processo de trabalho, observação de postos de trabalho, conversas com supervisores, encarregados e operários. A cada diálogo dentro da fábrica, eram apresentados, o pesquisador, seu vínculo institucional e os objetivos gerais da pesquisa.

As visitas ao chão de fábrica foram entremeadas por conversas com membros da equipe de segurança, cipeiros, trabalhadores e gerentes. Participou-se de palestras promovidas pelo setor de segurança (oferecidas semanalmente para as diferentes seções) e de reuniões técnicas de algumas equipes de trabalho. Participou-se, também, de uma reunião de CIPA e da semana de prevenção de acidentes, durante a qual se assistiu a uma peça de teatro escrita por trabalhadores. Além disso, esteve-se presente a uma reunião entre candidatos à CIPA da empresa, promovida pelo sindicato de trabalhadores e acompanhou-se os bastidores dessa eleição.

Procedeu-se, ainda, à análise das fichas de acidentes (cujas informações foram tabuladas e quantificadas) e de outros documentos da empresa, como textos sobre o Programa de Prevenção e Redução de Acidentes $^{14}$, apostilas, cartilhas e consolidados de dados sobre acidentes.

Embora o foco da investigação tenha sido os discursos de trabalhadores, foram colhidas falas de outras pessoas no decorrer do trabalho de campo, com a finalidade de identificar os

\footnotetext{
14 O Programa de Prevenção e Redução de Acidentes (PPRA) é uma exigência da Consolidação das Leis Trabalhistas (Capítulo V do Título II), constante da Norma Regulamentadora $n^{\circ}$ 9, que, entre outras determinações, exige a elaboração de um documento-base, ao qual se teve acesso.
} 
interlocutores dos primeiros. Dada a maior facilidade de acesso, o seu menor número e a boa qualidade dos dados colhidos durante as observações, não foram gravadas entrevistas com essas pessoas. De fato, não se acredita que os repertórios interpretativos encontrados sejam de uso exclusivo dos operários. Ao contrário - e os resultados da pesquisa ilustraram isso - esses repertórios estão disponíveis para todos na empresa, embora sejam usados, ou não, de formas muito diferentes pelos diversos grupos. Nesse sentido, Potter \& Wetherell (1987), ao compararem seu conceito de repertório interpretativo ao conceito moscoviciano de representação social, demostram como o primeiro supera os problemas metodológicos produzidos pelo segundo, por não ser intrinsecamente vinculado a grupos sociais específicos. Segundo os autores:

Em primeiro lugar, os repertórios não são construídos [teoricamente] como entidades intrinsecamente ligadas a grupos sociais, assim a pesquisa não tem sido obstruída pela necessidade de envolvimento no exercício freqüentemente problemático de identificar as fronteiras naturais dos grupos. No trabalho sobre bioquímicos, por exemplo, descobriu-se que todos os bioquímicos regularmente fazem uso de ambos repertórios interpretativos quando constroem suas explicações. Esses repertórios foram descobertos nos discursos de outros cientistas e até já foi sugerido que procedimentos interpretativos análogos são usados por profissionais da área de direito [...] Mais do que fazer a improvável pressuposição de que todas essas pessoas - bioquímicos, cientistas sociais, advogados - são membros do mesmo grupo social, é muito mais frutífero aceitar que os repertórios estão disponíveis para pessoas pertencentes ao mesmo tempo a diferentes grupos sociais e que os padrões explicativos podem não ser o modo mais engenhoso de subdividir a sociedade ou confirmar categorizações convencionais de grupos [p. 156, itálicos no original].

Assim, para a exemplificação dos repertórios interpretativos encontrados, entremearamse, em alguns casos, os discursos de trabalhadores com as falas de outros personagens da empresa.

Sendo as entrevistas um importante instrumento de investigação utilizado nesta pesquisa e tendo em vista a grande variedade que assumem em diferentes desenhos metodológicos, consideramos necessários alguns esclarecimentos sobre o tipo de entrevista realizada e sua justificativa em função do referencial teórico adotado, especialmente no que diz respeito à apreensão de repertórios interpretativos e aos aspectos retóricos dos discursos.

\subsection{Entrevista confrontativa}

As entrevistas, como instrumento de pesquisa, não são uma técnica capaz de revelar sem distorções um conjunto de opiniões pré-formadas nas mentes dos entrevistados. Elas, como outras situações sociais, são encontros nos quais cada interlocutor utiliza seus repertórios em função dos contextos interpretativos que as entrevistas instauram. Poder e status, como em 
qualquer outra relação social, perpassam essas interações e, assim, todo diálogo traz as marcas das diferentes inserções sociais dos interlocutores e dos desníveis existentes entre estas últimas.

Além disso, partindo de uma perspetiva dialógica (Shotter, 1992; Shotter, 1993), pode-se afirmar que os supostos conteúdos da mente individual não estão "lá dentro" prontos a serem revelados. Como um fenômeno de fronteira, a subjetividade constitui-se e estrutura-se ininterruptamente no interior de relações sociais. Essa é a proposta de Shotter (1993) quando afirma:

Em outras palavras, coerente com a visão de Wittgenstein, mais do que possuirmos pensamentos previamente ordenados e sistematizados no centro de nosso ser, os quais, em nossos enunciados, seriam meramente codificados em palavras, o que chamamos de "nossos pensamentos" apenas adquirem forma quando falamos ou escrevemos [...] ...nossas vidas "internas" são por nós estruturadas por vivermos "dentro" e "através", digamos assim, das oportunidades ou possibilidades a nós oferecidas pelos "outros" ao nosso redor e pelas "audiências" que internalizamos através da vivência em "esferas de comunicação" ou "gêneros de discurso" [p. 380].

Assim, quando buscamos com as entrevistas conhecer práticas discursivas de determinados atores sociais, elas devem ser conduzidas de modo a gerar "contextos interpretativos" que permitam ativar os diversos repertórios de que dispõem os entrevistados (Potter \& Wetherell, 1987). Como apontam Edwards \& Potter (1992) e Potter \& Mulkay (1985), dada a dependência contextual das práticas discursivas, o entrevistador deve explorar a sua variabilidade, naquilo que lhe é possível enquanto interlocutor. A esse tipo de procedimento dão o nome de entrevistas confrontativas. Potter \& Mulkay (1985) esclarecem sua proposta da seguinte maneira:

A característica crucial de nossa abordagem, então, é que não usamos as entrevistas, ou qualquer outra fonte de dados, para compor um retrato acurado das ações e crenças de seus participantes em campos específicos da vida social. Antes, usamos as entrevistas como uma técnica para gerar da parte dos participantes um trabalho interpretativo, com o objetivo de identificar os tipos de repertórios e métodos usados por eles e tendo como meta compreender como suas práticas interpretativas variam de acordo com as mudanças no contexto da interação. Embora tenhamos abandonado a hipótese tradicional de que podemos inferir das falas das entrevistas o que realmente acontece no campo social [...] assumimos que o trabalho interpretativo e de interação que ocorre nas entrevistas assemelha-se em alguma medida àquilo que acontece do lado de fora delas [p. 268].

Desse modo, Potter \& Wetherell (1987) sintetizam da seguinte maneira as características da entrevista mais adequada para os propósitos da análise de discurso:

Em resumo - as entrevistas na análise de discurso diferem das entrevistas convencionais de três formas. Primeiro, a variação nas respostas é tão importante quanto a sua consistência. Segundo, as técnicas que permitem a diversidade são mais enfatizadas do que aquelas que a eliminam, resultando em conversas mais informais e, terceiro, os entrevistadores são vistos mais como participantes ativos do que como algo semelhante a questionários-falantes [p. $165]$. 
Foram esses princípios que nortearam a realização das entrevistas na empresa-caso e a elaboração do roteiro que orientou essa tarefa.

Após a elaboração do roteiro de entrevistas com base nos objetivos da pesquisa, foram realizadas duas entrevistas-piloto que permitiram aprimorá-lo. Modificou-se a formulação das perguntas norteadoras e confirmou-se a viabilidade da proposta acima apresentada. Incluíram-se, ainda, informações importantes a serem fornecidas aos entrevistados no início da entrevista, dentre elas a ênfase redobrada na desvinculação da pesquisa com a empresa - dada a desconfiança manifestada em uma das entrevistas-piloto - e a desmistificação da imagem do psicólogo - que era visto como portador da capacidade de identificar pessoas insanas ou do poder de admissão e demissão de funcionários, através da mensuração de suas habilidades - preterida a favor das imagens de "curioso", "pesquisador" ou "repórter" (anexo b).

Quanto à definição da quantidade de entrevistas a serem realizadas, optou-se por um número suficiente para abarcar a diversidade e, ainda assim, ser passível de análise detalhada. A esse respeito, Potter \& Wetherell (1987) afirmam:

Por estar-se interessando no uso da linguagem [...] e pelo fato de um grande número de padrões lingüísticos emergir com grande probabilidade de poucas pessoas, pequenas amostras ou poucas entrevistas são em geral bastante adequadas para investigar um conjunto interessante e importante de fenômenos [p. 161].

A escolha dos entrevistados foi feita da seguinte maneira: definiu-se, com base nas observações, alguns setores representativos da empresa e o número de trabalhadores a serem entrevistados em cada um deles. Os trabalhadores foram convidados em função de sua disponibilidade de tempo. Depois de realizadas 20 entrevistas segundo esse procedimento, não se verificou a necessidade de realização de outras entrevistas, tendo em vista a grande variedade de discursos obtida e sua correspondência com achados de outras fontes ${ }^{15}$.

As entrevistas seguiram o roteiro modificado em função das entrevistas-piloto, das conversas informais e das observações. Elas aconteceram em uma sala reservada dentro do setor de segurança, ao lado do setor de recursos humanos. Foram gravadas com a permissão dos entrevistados e posteriormente transcritas.

\footnotetext{
15 Foram entrevistados ao todo 14 operadores, 3 montadores, 1 ferramenteiro, 1 instalador de manutenção e 1 inspetor de qualidade. Eles tinham entre 23 e 45 anos (média de 34,60 anos). Quanto ao local de nascimento, 9 entrevistados nasceram em outros estados, 2 nasceram no interior de São Paulo e 9 na Grande São Paulo. Quanto à escolaridade, 7 tinham primeiro grau incompleto, 4 tinham primeiro grau completo, 7 tinham segundo grau incompleto e 2 tinham segundo grau completo. Antes de entrarem na empresa-caso, tiveram diversas outras ocupações. Dos que nasceram em outros estados, muitos declararam ter trabalhado na agricultura. Todos, antes de ocuparem a função atual, foram ajudantes. Alguns outros trabalharam no setor terciário. No momento da pesquisa, estavam, em média, há 9,36 anos na empresa e há 6,84 anos na função. Ainda: $75 \%$ eram sindicalizados, $80 \%$ declararam já ter feito curso de saúde e segurança (embora todos assistissem às palestras semanais oferecidas
} 
Antes das entrevistas era feita uma apresentação, na qual se descreviam os objetivos da pesquisa e salientavam-se os seguintes aspectos: a não vinculação com a direção da empresa; o interesse e o valor conferido ao conhecimento operário pelo pesquisador e seu envolvimento com o tema dos acidentes; o acaso da escolha e o fato de estarem sendo entrevistadas várias outras pessoas; o anonimato e a liberdade do entrevistado para falar o que bem quisesse; a natureza da entrevista, caracterizada como uma espécie de "bate-papo"16.

A estrutura do roteiro de entrevista procurou criar, por meio de perguntas, contextos interpretativos nos quais os entrevistados pudessem utilizar diferentes repertórios. Elas foram dividas em três partes, as duas primeiras baseadas em perguntas-norteadoras e a terceira em perguntas sobre os temas abordados pelos entrevistados.

A primeira parte das entrevistas teve por objetivo iniciar a conversa, permitir aos entrevistados voltarem seus pensamentos aos acontecimentos do trabalho e coletar informações de interesse sobre suas atividades e o funcionamento da empresa-caso. Assim, solicitava-se aos entrevistados que contassem sobre sua história ocupacional, explorando-se temas como sua origem, os lugares onde já trabalhou e a descrição de seu trabalho atual.

Na segunda parte, pedia-se aos entrevistados que falassem sobre os acidentes de trabalho. Caso solicitassem esclarecimentos, formulavam-se perguntas relativas à razão dos acidentes ou à sua causalidade. Após um certo tempo de livre expressão (em geral encerrado pelos próprios entrevistados, que declaravam ter falado o bastante ou pediam que perguntas fossem feitas), alguns recursos eram utilizados para explorar suas concepções a respeito dos acidentes, como pedir para relatarem algum acidente, para que falassem sobre formas de prevenção ou que explicassem melhor as causas apresentadas.

$\mathrm{Na}$ terceira parte, procurava-se - a depender das circunstâncias e do desenrolar de cada conversa - argumentar com os entrevistados, confrontando as diferentes concepções por eles apresentadas ou confrontando-as com as de outros trabalhadores. Essa estratégia contribuiu para que se conhecessem os argumentos e contra-argumentos utilizados para sustentar algumas posições e combater outras. Encerradas as entrevistas, aplicava-se um pequeno questionário ${ }^{17} \mathrm{e}$

pela empresa e muitos as classificassem como sendo um curso), $30 \%$ já foram cipeiros e $50 \%$ declararam ter sofrido algum tipo de acidente.

${ }^{16}$ Alguns entrevistados comentaram: "Ah, que nem pesquisa mesmo!", fazendo alusão às pesquisas de opinião, diferentes das entrevistas com psicólogos de empresas, associadas a diagnósticos ou avaliações.

${ }^{17}$ Com a finalidade de coletar informações como: idade, local de nascimento, escolaridade, função, máquina em que trabalha, tempo na empresa, tempo na função, funções anteriores, filiação ao sindicato, participação em CIPA, participação em curso de segurança, ter sofrido ou não algum tipo de acidente do trabalho (anexo b). 
firmava-se o compromisso de devolutiva dos dados para os trabalhadores, o sindicato e a empresa.

Feita a exposição da metodologia adotada, passa-se à apresentação dos resultados. 


\section{O ITINERÁRIO DAS IDÉIAS PSICOLOGIZANTES NO IMAGINÁRIO SOCIAL}

O objetivo deste capítulo é apresentar o pano de fundo sobre o qual foi feita a análise das práticas discursivas cotidianas. Desse modo, procurou-se identificar as principais teorias de acidentabilidade e destacar as formas pelas quais a psicologia abordou o assunto.

As idéias produzidas nos meios especializados de higiene e segurança do trabalho, pela sua ampla difusão, refletem o pensamento constituído a respeito dos acidentes de trabalho em nosso meio social. O conhecimento do debate no campo da acidentologia facilitará a identificação da presença dessas idéias no pensamento do senso comum e permitirá avaliar suas transformações ao serem inseridas no chão de fábrica.

\subsection{As teorias de acidentabilidade e as idéias psicologizantes}

Diversas teorias sobre a produção dos acidentes foram elaboradas por especialistas de distintas áreas desde os primórdios da revolução industrial. Um panorama das principais teorias é de grande utilidade para as finalidades desta pesquisa, tendo em vista que o seu conjunto integra o contexto discursivo sobre o qual as explicações contemporâneas são enunciadas. Assim, uma síntese das principais teorias é apresentada a seguir (para outras revisões ver: Arouca, 1975; Carmo \& cols., 1995; Singleton, 1973; Vidal, 1991). Salienta-se que a seqüência em que se encontram não corresponde necessariamente à cronologia de seu aparecimento e, muitas vezes, algumas delas apareceram ou ainda aparecem simultaneamente.

A primeira abordagem para a explicação dos acidentes a ser tratada aqui tem como principal conceito a chamada "propensão a acidentes". Segundo McKenna (1983), o termo foi utilizado pela primeira vez em 1919 pelos britânicos Greenwood e Woods ${ }^{18}$. Tal conceito referese à suposta existência de "traços de personalidade", portanto características estáveis, que levariam alguns indivíduos a sofrerem mais acidentes que outros. Tal suposição foi derivada das observações de Greenwood e Woods de que, em uma população trabalhadora, um pequeno número de operários era vitimado pela maioria dos acidentes. 
Segundo Szasz (1984), a propensão a acidentes foi o mais cultuado conceito acidentológico das décadas de 20 e 30 nos Estados Unidos. Foi abandonado definitivamente na década de 50 pela comunidade científica, exceto por autores de orientação psicanalítica que "continuaram afirmando haver algo na estrutura psicodinâmica da personalidade de certos trabalhadores que os levariam a ser propensos ao acidente" (Szasz, 1984). Referências críticas a abordagens psicanalíticas dos acidentes de trabalho também aparecem em Arouca (1975), Singleton (1973) e Carmo \& cols. (1995).

Algumas das críticas que derrotaram o conceito de propensão a acidentes foram as seguintes: trata-se de um modelo unicausal e que não leva em conta as condições reais de trabalho; as pesquisas por ele inspiradas não conseguiram estabelecer correlações significativas entre traços de personalidade e índices de acidentes e a própria idéia de "traços" estáveis de personalidade caiu por terra; problemas referentes à notificação dos acidentes analisados nessas pesquisas foram encontrados e suas distribuições passaram a ser interpretadas de outras formas, por exemplo, como uma distribuição aleatória e variável, isto é, sem relação com características de quem sofreu os acidentes, pois se observaram modificações no decorrer do tempo da composição dos pequenos grupos de indivíduos que sofriam a maioria dos acidentes. Uma análise revelando o papel ideológico desse conceito é apresentada por Szasz (1984), que traça sua trajetória, do nascimento até a rejeição por parte da comunidade científica.

Apesar do seu atual "esquecimento" (o que, como veremos adiante, pode não corresponder diretamente à realidade brasileira, por exemplo: Rodrigues, 1984 e Murakoshi, 1995), Szasz afirma que a idéia da propensão a acidentes

continua sendo útil ao gerenciamento como uma ideologia. O conceito difundiu-se através da cultura e atingiu o status de senso comum. A ideologia produzida pelas disciplinas científicas infiltrou-se na opinião pública através do processo de difusão e degradação.

Dessa forma, se explicações equivalentes à de propensão não são mais usadas com status de "conhecimento científico", deixaram no entanto suas marcas nos modos de percepção social da realidade.

Uma outra maneira de abordar os acidentes, variante do conceito de propensão, foi fornecida pela "teoria da acidentabilidade" (analisada por Vidal, 1991). Baseada no taylorismo, propunha que "a existência de acidentes era devida, basicamente, à inadaptação do perfil do posto de trabalho às características dos indivíduos que o ocupassem” (p. 11). A sua prevenção,

18 Greenwood, M. \& Woods, H.M. (1919). The Incidence of Industrial Accidents upon Individuals with Special Reference to Multiple Accidents. Industrial Fatigue Research Board: relatório no 4. His Majesty's Stationery Office, Londres. 
portanto, encontrar-se-ia nas práticas de seleção e treinamento. A idéia de traços estáveis permanecia, mas se começava a considerar sua interação com o posto de trabalho.

Esses dois conceitos foram praticamente abandonados (embora reapareçam vez ou outra em revistas conceituadas, por exemplo: Porter \& Corlett, 1989), mas não se pode dizer o mesmo da busca por variáveis determinantes do acidente localizadas no indivíduo, reunidas sob o rótulo de "fatores humanos" no trabalho. Essa busca passa a ser, então, por características individuais temporárias e não estáveis, de natureza fisiológica ou psicológica, que estariam associadas aos acidentes e que seriam determinadas, ou não, pelo contexto de trabalho.

O estabelecimento, por exemplo, da relação entre fadiga e acidentes remonta ao início do século e é referida por Münsterberg no livro Psychology and Industrial Efficiency, de 1913. A relação entre estresse e acidentes de trabalho foi também relatada (Ríos, Moreno-Jimenez \& García, 1987).

Com relação às características individuais temporárias de natureza psicológica, foram apontadas entre outras: comportamentos inseguros, situações de crise ou comoção emocional.

Outro modelo explicativo bastante difundido entre os especialistas de higiene e segurança no trabalho é a Teoria dos Dominós de Heinrich (1959), da qual derivam os conceitos de ato inseguro e condição insegura. Segundo o autor, o acidente seria causado por uma cadeia linear de fatores que culminariam na lesão: "A ocorrência de uma lesão passível de prevenção é a culminação natural de uma série de eventos ou circunstâncias, as quais ocorrem invariavelmente seguindo uma ordem lógica e fixa" (p. 15), exatamente como um seqüência de dominós dispostos alinhadamente, de modo que a queda de um levaria à queda dos seguintes (figura b).

Figura B: A "Teoria dos Dominós" de Heinrich.
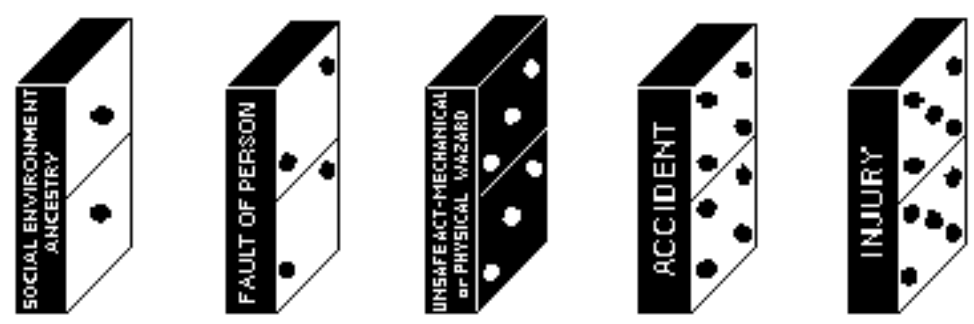

The five factors in the accident sequence.

Fonte: Heinrich (1959: p. 14).

Essa cadeia iniciar-se-ia com os "fatores sociais e ambientais prévios", que seriam responsáveis pela formação do caráter dos operários. As características herdadas ou adquiridas pelo trabalhador em seu meio levariam-no a ter comportamentos inadequados no trabalho, considerados por Heinrich como a segunda peça de dominó. Esses comportamentos poderiam 
tomar a forma de atos inseguros, isto é, poderiam ser comportamentos de risco que, juntamente com a presença de condições inseguras, levariam à ocorrência do acidente, que por sua vez causaria a lesão, o evento final desse processo linear. Segundo Heinrich, o fator chave para a interrupção da cadeia causal do acidente refere-se aos atos inseguros e às condições inseguras: eliminados um desses elementos, o acidente não aconteceria. Entretanto - e isto é crucial para compreender a ampla difusão das idéias heinrichianas - o autor sugere que uma maior ênfase preventiva deveria recair sobre o comportamento dos trabalhadores, pois $88 \%$ dos acidentes seriam provocados por atos inseguros e apenas os restantes pelas condições inseguras.

Silva (1995) aponta para as limitações explicativas da teoria heinrichiana e para sua característica de atribuição de responsabilidades:

Por este modelo fica patente o seu perfil mecanicista e cartesiano de uma forma linear, que empobrece e distorce imediatamente a análise, obscurecendo a real causalidade e servindo essencialmente à imputação de responsabilidades no universo de acidentes de trabalho, além do seu julgamento de valor inserido na análise [p. 38].

Santos (1991) também afirma que:

a perspectiva que recorre à dicotomia "atos inseguros-condições inseguras", além da pouca capacidade explicativa, serve também para mistificar as condições gerais do processo de trabalho. As análises do acidente que partem do exame da lógica global que preside à totalidade desse processo facultam o aparecimento de novos elementos e de uma diferente articulação entre eles [p. 97].

Apesar dessas limitações, o modelo de Heinrich encontra-se amplamente difundido e utilizado no meios de higiene e segurança no trabalho (Silva, 1995), o que também se revelou verdadeiro no estudo de caso realizado.

Outras vertentes interessaram-se por aspectos cognitivos ou perceptuais relacionados aos acidentes ou pelo efeito favorável aos acidentes que os fatores ambientais (como iluminação, calor, ruído) teriam sobre a cognição e a percepção dos trabalhadores. Essas, diferentemente das primeiras, procuram salientar a relação homem-máquina-contexto de trabalho e suas influências múltiplas (Leplat \& Cuny, 1983), já dentro de uma visão sistêmica (Achcar, 1989; Leplat, 1984; Vidal, 1991) ou de ergonomia cognitiva, descartando a abordagem unicausal.

Quanto às abordagens de cunho psicossocial, pode-se citar aquelas que se interessaram pelas relações entre os próprios trabalhadores e entre trabalhadores e empresários ou seus representantes (por exemplo, estudos sobre motivação: Borja \& Martinez, 1991) ou pelo "clima organizacional" (Zohar, 1980) ou, ainda, pela organização do trabalho (um exemplo, tirado da sociologia do trabalho, é Dwyer \& Raftery, 1991) como determinantes dos acidentes. Nesses casos também são modelos multicausais que estão em jogo. 
Dentre as abordagens multicausais, a que mais se destaca é a teoria de fiabilidade de sistemas. Essa teoria compreende a fábrica como um sistema aberto no qual o acidente seria um produto (output) ocasionado por falhas do próprio sistema, relacionadas à manutenção da estabilidade no decorrer de uma série histórica (Vidal, 1991). Foi no interior dessa abordagem que se desenvolveu o método de investigação de acidentes de trabalho denominado "árvore de causas", muito em voga atualmente (Binder \& cols., 1996). Com a teoria de sistemas abre-se a possibilidade para uma compreensão dos acidentes que leva em conta a sua complexidade, que não reduz a análise aos fatores imediatos que conduziram ao seu acontecimento e na qual se diminuiu o peso conferido pelas teorias anteriores aos fatores individuais, que não foram excluídos, mas foram definidos como elementos dentro de uma rede de inter-relações entre diversos outros elementos. Entretanto, tanto as abordagens sistêmicas quanto as abordagens psicossociais têm o seu alcance limitado por um foco restrito ao micro-ambiente de trabalho, diferentemente da abordagem sociológica de Cohn \& cols. (1985).

Segundo Minella (1993), a abordagem sociológica procura demonstrar "que o acidente de trabalho, longe de ser uma fatalidade ou uma responsabilidade do trabalhador, decorre de fatores objetivos presentes no processo de organização do trabalho" (p. 64). Assim esse enfoque passa a levar em consideração os determinantes macrossociais e políticos dos acidentes de trabalho.

Da mesma forma, o enfoque sindical supera as abordagens restritas ao micro-ambiente da fábrica e conduz uma análise política da situação dos acidentes no Brasil a fim de constituir propostas de luta para o movimento sindical (Minella, 1993).

Assim como a visão sistêmica, os dois enfoques acima referidos - sociológico e sindical reconhecem nas explicações centradas nos fatores humanos um mecanismo de atribuição de responsabilidade dos trabalhadores pelos seus acidentes.

A seguir, veremos como essas explicações foram encampadas por especialistas brasileiros e deixaram suas marcas no imaginário social.

Entretanto, antes dessa incursão, considerou-se importante apresentar outras maneiras pelas quais a psicologia abordou os acidentes de trabalho. Como veremos, a apropriação do acidente como objeto dessa disciplina foi muito além da busca de modelos explicativos, revelando o grande interesse que o assunto despertou nos psicólogos. Pretende-se assim demonstrar a constante presença e a influência que tiveram as idéias psicológicas nas formas contemporâneas de apropriação das diversas facetas desse fenômeno. 


\subsection{A psicologia e o acidente de trabalho' ${ }^{19}$}

Dentre as teorias acidentológicas apresentadas acima, existem aquelas que recorreram a estudos voltados para a descoberta de causas ou fatores de ordem fisiológica, psicológica ou psicossocial relacionados à ocorrência dos acidentes de trabalho. $\mathrm{O}$ acidente, nesses trabalhos, foi definido como variável dependente e os fatores investigados, como variáveis independentes ${ }^{20}$. A ênfase em uma ou outra variável independente modificou-se no decorrer da história das idéias psicológicas aplicadas ao trabalho. A passagem de modelos unicausais para modelos multicausais também pode ser constatada, embora os primeiros ainda apareçam em trabalhos recentes.

Todos esses estudos tiveram como objetivo principal a prevenção dos acidentes, que se caracterizou por intervenções sobre os fatores causais identificados ou pela exclusão dos indivíduos com determinadas características psicológicas por meio, por exemplo, de técnicas de seleção.

Mas não foi apenas em busca de suas causas que a psicologia elegeu os acidentes como objeto de estudos. Um breve olhar sobre sua produção ${ }^{21}$ permite vislumbrar outras formas distintas de abordagem do problema. Essas grandes áreas de atuação incluem estudos sobre a atribuição de causalidade do acidente, a percepção de riscos, as reações psíquicas diante dos riscos, as repercussões psíquicas dos acidentes de trabalho e técnicas de reabilitação dos trabalhadores acidentados.

Os estudos de psicologia da atribuição voltados para o acidente de trabalho não procuram explicar diretamente a sua ocorrência, mas compreender como o senso comum estabelece relações de causais. O objeto da psicologia da atribuição não é o acidente em si - portanto não se trata de uma teoria acidentológica - mas a maneira como os próprios trabalhadores estabelecem a relação entre variável dependente (o acidente) e as variáveis independentes (as “causas”).

Essa área reúne estudos que visam vários objetivos, dentre eles os seguintes: conhecer as atitudes dos trabalhadores diante dos acidentes a fim de prever seu comportamento ou planejar campanhas de prevenção (Queiroz \& Novaes, 1980); conhecer os possíveis vieses de

\footnotetext{
${ }^{19}$ Uma versão preliminar desta seção foi apresentada na forma de painel durante o III Congresso Interno do Instituto de Psicologia da USP, nos dias 20 e 21 de novembro de 1995, sob o título: Acidente de Trabalho e Psicologia: Revisão Crítica das Áreas de Atuação.

20 Os conceitos de "variável dependente" e "variável independente" foram utilizados de forma abrangente, num sentido mais amplo do que a sua formulação original. Sua escolha e o tipo de uso deu-se simplesmente pela facilidade demonstrada em explicitar as diferenças entre as abordagens aqui discutidas, embora nem todas as teorias apresentadas alinhem-se com a tradição epistemológica que deu origem a tais conceitos.

${ }^{21}$ Foram consultadas as bases de dados PsyLIT, Nioshtic e Cisilo, atualizadas até o ano de 1994.
} 
interpretação do acidentes pelos envolvidos (Dela Coleta \& cols., 1986); permitir, em uma abordagem sistêmica, a compreensão integrada da interação dos vários elementos que compõem um sistema (Achcar, 1989); ou, ainda, permitir a elucidação dos determinantes sociais das representações dos acidentes (Barjonet, 1980).

Alguns exemplos dos achados dessas pesquisas: o acidente poderia ser atribuído a variáveis internas (o próprio acidentado) e externas (outras pessoas, condições materiais ou o acaso); diferenças foram encontradas entre as atribuições de acidentados e observadores (Dela Coleta, 1980) e entre ocupantes de diferentes níveis hierárquicos nas empresas (Dela Coleta \& cols., 1986).

Os estudos sobre percepção de riscos são um tipo de pesquisa muito presente em países da Europa, voltados especialmente para a definição de políticas relacionadas a riscos ambientais (ver: Slovic, 1987). O estudo de Dionne-Proulx (1992) é um exemplo da identificação de riscos do ambiente de trabalho relativos a acidentes dentro dessa abordagem.

Utilizando os recursos trazidos pelos estudos de atribuição e pela tradição psicométrica, os estudos sobre percepção de riscos procuraram dar conta da maneira como os indivíduos percebem e avaliam esses riscos, não para saber como compreendem ou explicam sua causalidade, mas como tomam consciência de sua existência e a eles respondem. Estuda-se a avaliação, pelos trabalhadores, das probabilidades da ocorrência de um acidente e não a explicação causal ou atribuição de responsabilidade por esse. Os objetivos principais desse tipo de pesquisa podem ser sintetizados da seguinte maneira: prever as respostas aos riscos, no caso de introdução de novas tecnologia, apresentadas pelos trabalhadores ou pela população em geral (Slovic, 1987); elucidar o processo de tomada de decisão do trabalhador e sua capacidade de antecipação do perigo; fornecer subsídios para influenciar a atitude e a motivação dos trabalhadores no sentido da adoção de medidas de segurança; influenciar a comunicação dos riscos aos trabalhadores; estimar a aceitabilidade dos riscos; fornecer elementos para a definição de políticas empresariais ou governamentais. Otway \& Thomas (1982) discutiram as implicações políticas desse tipo de estudo, apontando que tais pesquisas, em última instância, visariam legitimar as decisões, empresariais ou governamentais, referentes à introdução de novos riscos e à sua mudança para outras regiões geográficas.

Em uma outra vertente, a psicopatologia do trabalho, Dejours (1988) aponta como as estratégias defensivas adotadas pelo coletivo de trabalhadores influenciam a percepção dos riscos presentes no ambiente de trabalho. Essas estratégias funcionariam como mecanismos de defesa através dos quais os perigos seriam mitigados. O autor cita como exemplo a "ideologia ocupacional defensiva" dos trabalhadores da construção civil francesa, dentre os quais o perigo é 
mantido distante da consciência por meio, por exemplo, da valorização da coragem e da expressão de bravura.

Uma outra linha de estudos, ainda, que destoa daquelas acima apresentadas pelas suas diferenças teóricas e metodológicas, mas que tem afinidade com o estudo da compreensão que têm os trabalhadores das condições de trabalho a que estão submetidos, refere-se ao "modelo operário italiano" (Odonne \& cols., 1986) e outros estudos com abordagem semelhante (Grimberg, 1991; Sato, 1991) que não trabalham com o conceito de "percepção de riscos", mas com o que denominaram "conhecimento operário" (Oddone \& cols., 1986; Sato, 1992). Esses trabalhos caracterizam-se por um método de acessar a realidade fabril a partir da percepção dos trabalhadores, visando a modificação das condições de trabalho e envolvendo a participação de sindicatos.

Uma terceira área de atuação refere-se aos estudos sobre as reações psíquicas diante dos riscos. Nessa área, encontram-se estudos que investigaram os efeitos psíquicos e psicossociais da exposição a riscos nos ambientes de trabalho, sem entrar em questões de causalidade do acidente, de natureza epistemológica ou de percepção. Os riscos para acidentes são tomados como variáveis independentes e suas repercussões psíquicas e psicossociais como variáveis dependentes.

Um exemplo dessa área de estudos também é a psicopatologia do trabalho de Dejours (1988), que tem entre seus interesses o estudo das reações individuais e coletivas dos trabalhadores diante dos riscos. Dejours apontou mecanismos individuais e coletivos utilizados pelos trabalhadores para enfrentar os efeitos da organização do trabalho e a ameaça dos riscos existentes no ambiente da fábrica. Rangel-Santos (1992), de maneira similar a Dejours, estudou a constituição de uma "cultura de risco" em empresas petroquímicas, revelando os mecanismos coletivos de defesa que a compunham. Brody (1988), por sua vez, estudou as reações de estresse e "coping" de trabalhadores siderúrgicos relacionadas à exposição a riscos ocupacionais.

A tônica desses trabalhos dá-se em dois aspectos: a preocupação com a preservação da saúde mental dos trabalhadores e a identificação dos efeitos nocivos sobre ela, causados pela presença de riscos no trabalho. A compreensão dos modos pelos quais os trabalhadores, individual ou coletivamente, enfrentam tal ameaça e conseguem sobreviver, se não ao sofrimento, ao menos às manifestações patológicas.

Além das reações psíquicas diante dos riscos, são também estudadas as repercussões psíquicas de sofrer ou de presenciar acidentes de trabalho. Tomam-se aqui como objeto de estudo os efeitos psíquicos da ocorrência dos acidentes, tanto sobre o trabalhador acidentado 
quanto sobre seus companheiros. Suas conseqüências para os trabalhadores vitimados passam pela dor, indignação, limitações físicas, incapacidade para o trabalho, desarticulação da identidade, tendo inclusive repercussões sobre a família e sobre todas as relações interpessoais. A ocorrência do acidente também significa, para os outros trabalhadores, a lembrança de que eles próprios poderiam ser as vítimas.

Bertolli-Filho (1993), ao estudar a implantação das idéias psicológicas no Brasil durante a consolidação do processo de industrialização, revela como na década de 40 as chamadas "ciências do comportamento" criaram "conceitos nosológicos" absurdos para descrever os "transtornos mentais" resultantes dos acidentes. Solicitados a "atuarem como peritos em processos judiciais" devidos a "pedidos de indenizações movidos pelos operários acidentados", os peritos em psicologia industrial da época:

convergiam para o diagnóstico da existência de traumatismos físicos favorecedores do desenvolvimento de "neuroses de responsabilização" dos patrões pelo acidente de trabalho, sentimento rotulado pela medicina como "sinistrose", "neurose de renda", "neurose de desejo" e "indenizofilia". Apesar da pluralidade de denominações, a "patologia" que acometia os trabalhadores acidentados contava com definição única: "um delírio pleitista, querelante, de reivindicação" [p. 46].

Mais recentemente, Weisaeth (1989) referiu-se a um quadro denominado Síndrome de Estresse Pós-Traumático ou Síndrome Pós-Traumática encontrado em trabalhadores acidentados e trabalhadores que estavam trabalhando durante a ocorrência de acidentes. A síndrome incluiria, entre outros, sintomas de depressão, apatia ou ansiedade e medo de retornar ao trabalho, variáveis de acordo com a participação direta ou indireta do acidente.

Cohn \& cols. (1985) e Hirano, Redko \& Ferraz (1990) - numa outra perspectiva referiram-se ao acidente como sendo o ápice da perda de cidadania pelo trabalhador, que se inicia pela imposição de condições perigosas de trabalho, passando pela desigualdade dos direitos sociais, previdenciários e do acesso a serviços de saúde em nossa sociedade.

Com base no conhecimento das repercussões psíquicas dos acidentes e das limitações físicas impostas, estuda-se também o retorno dos trabalhadores acidentados ao processo produtivo, que se considerou como sendo mais uma área de atuação, distinta das anteriores. A reabilitação, no que compete ao psicólogo, vem se dando dentro do modelo tradicional da psicologia clínica e com ênfase na orientação e no aconselhamento psicológicos. Esse tipo de trabalho tem que dar conta de várias questões: a possibilidade de retorno à mesma função; a adaptação a uma nova função, se for o caso; o enfrentamento da nova situação de vida e todas as suas implicações. 
Essas seis áreas arroladas distinguem-se, dentre outras coisas, pelas diferentes distâncias que tomam do fenômeno acidente de trabalho e pelas variáveis dependentes e independentes que adotam.

A investigação das causas dos acidentes do trabalho toma o próprio acidente como objeto da psicologia, definindo-o como variável dependente e os fatores fisiológicos, psicológicos e psicossociais como variáveis independentes. A segunda área de atuação toma as explicações - e não o próprio fenômeno - como objeto e tenta elucidar como o senso comum estabelece relações de causalidade. Os estudos de percepção de riscos mantém o interesse no pensamento do senso comum, mas abandonam a questão causal, pois estão interessados no cálculo da probabilidade de ocorrência de acidentes realizado pelos trabalhadores, o que depende, é claro, das teorias implícitas ou explícitas adotadas por eles, mas se constitui em um interesse de outra ordem. Apesar das diferenças apontadas, todas essas três áreas têm, em última instância, o objetivo de prevenir os acidentes.

As três áreas restantes, por sua vez, estão interessadas na relação entre a subjetividade dos trabalhadores e a possibilidade ou a ocorrência dos acidentes. Assim, apresentam uma inversão: dessa vez a subjetividade dos trabalhadores é a variável dependente e os riscos, os acidentes e suas conseqüências, as variáveis independentes. A compreensão das reações psíquicas diante dos riscos interessa também ao objetivo de prevenir acidentes. Os estudos sobre o trabalhador acidentado e a sua reabilitação - situação em que as medidas de prevenção não foram suficientes e o acidente está consumado - preocupam-se com a recuperação da força de trabalho e sua rápida reinserção no processo produtivo.

Como se pôde ver, a psicologia vem há muito tempo produzindo conhecimentos e realizando intervenções sobre as causas e as conseqüências dos acidentes de trabalho. Essa influência somada às idéias psicológicas produzidas na acidentologia deram margem a um olhar sobre os acidentes que reduz suas causas a fatores pessoais ou estritamente psicológicos. É sobre esse olhar relativo às causas que recairá nossa análise.

\subsection{A difusão das idéias psicologizantes sobre o acidente de trabalho no Brasil}

Isaac Prilleltensky recentemente afirmou que a psicologia, independentemente dos efeitos positivos ou negativos de suas práticas, tem consideráveis repercussões sobre a sociedade (Prilleltensky, 1994). Entretanto, segundo o autor, a grande contribuição da psicologia tem sido 
para a manutenção do status quo, já que fornece elementos para a legitimação e naturalização de determinadas relações de poder.

Rose (1990) aponta o caminho seguido pela psicologia para tornar-se uma "ciência" do controle racional dos fatores humanos:

A tradução do indivíduo para o campo do conhecimento tornou possível governar a subjetividade de acordo com normas que reivindicam o status de ciência, utilizadas por profissionais que embasam sua autoridade em um conhecimento esotérico, porém objetivo. $\mathrm{Na}$ escola, na fábrica, na prisão, no exército, os psicólogos tornaram-se especialistas na utilização racional do fator humano. A psicologia começou a reivindicar a capacidade não apenas de individualizar e classificar, mas também de opinar sobre todas as facetas da vida institucional, para aumentar a eficiência e a satisfação, a produtividade e o contentamento [p. $110]$.

Essa utilização racional dos fatores humanos chega também aos acidentes de trabalho. Desde sua entrada nas fábricas, os psicólogos têm opinado sobre a prevenção de acidentes, fazendo uso de suas técnicas "objetivas" - a psicometria em particular - para excluir os trabalhadores "propensos a acidentes" ou para adequá-los às suas tarefas, sob o pretexto de encontrar "o homem certo para o lugar certo". Essa entrada no mundo do trabalho não foi certamente conseqüência da simples predileção dos "homens de ciência" pelo tema, mas do papel social atribuído a esses profissionais e da formação a eles oferecida.

No Brasil da década de vinte, a crescente industrialização trouxe para dentro das fábricas milhares de camponeses e imigrantes que - não familiarizados com as máquinas, as longas jornadas de trabalho e a disciplina imposta pelos imperativos da produção - apareciam para as elites de então como uma ameaça às suas intenções "progressistas" e "modernizadoras". Tendo claro que os conflitos e problemas que ameaçavam a produção eram frutos da ação de "degenerados morais" (Bertolli-Filho, 1993), os higienistas da época propunham, com base na Organização Científica do Trabalho, a utilização de métodos "científicos" para a seleção e ajustamento dos operários à vida na fábrica. Suas práticas de intervenção nascem, portanto, como uma resposta às solicitações das elites emergentes daquela época.

Médicos como Afrânio Peixoto, Flamínio Fávero e Leonídio Ribeiro lideravam esse movimento. Na mesma década, grandes nomes da psicotécnica, como Henri Piéron e Léon Walther, tiveram suas vindas ao Brasil patrocinadas por empresários e, na década seguinte, surgiram diversas instituições voltadas para o desenvolvimento das "ciências do comportamento", como, por exemplo, o Instituto de Organização Racional do Trabalho (IDORT), fundado em São Paulo no ano de 1928, conforme relata Bertolli-Filho (1993). Ainda, segundo o mesmo autor: 
A ênfase conferida à análise do comportamento individual e coletivo dos agrupamentos operários incentivou que diferentes pesquisadores convergissem para enfoques psicológicos dos trabalhadores, resultando no fato que especialmente os médicos, mas também os pedagogos, os advogados e os cientistas sociais reclamassem para si o título de psicólogos, se não de psiquiatras e psicanalistas. Processo marcado pela lentidão nos anos 30 , na década seguinte ganhou projeção a "medicina do comportamento" que, incluindo a psicotécnica, firmou-se como dispositivo para a dissecação e julgamento da rotina e das disfunções que caracterizavam o cotidiano industrial [p. 39].

Com seus testes e técnicas de entrevistas clínicas em punho, os "psicologistas" propunham-se a afastar das fábricas, por meio da identificação de distúrbios psicológicos, os "desajustados" ou "inadaptados" que ameaçavam a produção, promoviam conflitos e causavam acidentes.

As idéias de propensão individual aos acidentes propostas por Greenwood e Woods tiveram seu auge nessa época. Segundo o Dr. João de Barros Barreto no periódico Archivos de Hygiene, de 1929:

A doutrina da interferência, em muitos acidentes, de uma verdadeira suscetibilidade individual, hoje assenta em base sólida, firmada sobretudo pelas verificações conduzidas pelo Industrial Fatigue Research Board, da Inglaterra [...] Greenwood, primeiramente em 1919, Newbold, cinco anos mais tarde, mostraram por métodos estatísticos que, como diferem os indivíduos em altura, em peso, na força muscular... também diferem na predisposição aos acidentes [Barreto, 1929: p. 245].

Mas foi na década de 40 que as "ciências do comportamento" consolidaram seu papel enquanto mecanismo de controle do operariado e apaziguador dos conflitos industriais. Segundo Bertolli-Filho (1993):

No final da década de 40, as "ciências do comportamento" firmavam presença nos debates acerca da organização e gerenciamento do trabalho. Momento de redefinição da economia e da política nacional, as atividades produtivas recebiam novas tinturas de modernidade, reiterando o papel da medicina e de seus desdobramentos enquanto dispositivos atualizadores da força de trabalho e do código de vivência nas fábricas e na área de prestação de serviços. A soma do projeto psicotécnico com a avaliação "psicológica" do operariado, especialmente da parcela dos acidentados, abre oportunidade para a verificação de alguns mecanismos de controle do trabalhador brasileiro, os quais tendiam a imputar o afloramento das contradições permeadoras do cotidiano e do espaço de labuta aos operários vitimados pelos comportamentos "desajustados", negando a importância dos movimentos de desagrado enquanto canais de relacionamento entre o capital e o trabalho [p. 51].

Na década de setenta, em plena ditadura militar, renova-se o interesse pelas contribuições que a psicologia poderia oferecer aos problemas do mundo do trabalho. A introdução de psicólogos nas fábricas era acalentada por representantes do poder público como uma importante medida de prevenção dos acidentes, que aumentaram vertiginosamente durante o chamado "milagre econômico". 
O Dr. Eduardo Gabriel Saad, secretário-executivo do XV Congresso Nacional de Prevenção de Acidentes do Trabalho, ocorrido no ano de 1976, fala da importância da seleção e treinamento para a prevenção dos acidentes:

Ninguém mais discute que inúmeros acidentes do trabalho poderão ser evitados se através da correta seleção forem escolhidos os empregados com aptidões físicas e psicológicas para um determinado trabalho. De outra parte, não se duvida que o empregado, depois de submetido a cuidadoso treinamento, saberá cumprir sua tarefa sem precisar expor-se a riscos que provocam acidentes [Saad, 1976: p. 5].

Expressando concordância com as afirmações acima, foram feitas durante o congresso sugestões para a obrigatoriedade da inclusão de psicólogos nas equipes de higiene e segurança no trabalho das empresas:

No tratamento dessas variáveis humanas, relacionadas com os acidentes de trabalho, tem papel de destaque o psicólogo [...] No XV CONPAT chegou-se a várias conclusões e recomendações a respeito do assunto, merecendo menção especial aquela que propõe a inclusão do psicólogo na equipe que, obrigatoriamente, deve compor o Serviço Especializado em Segurança e em Higiene e Medicina do Trabalho [Saad, 1976: p. 5].

Outro participante do XV CONPAT, o engenheiro Fernando Nunes de Lima, ao comentar as causas dos altos índices de acidentes no Brasil, revela um otimismo desmedido em relação aos progressos na eliminação de riscos ambientais e afirma:

As raízes do problema residem na formação imperfeita dos homens. Os acidentes não acontecem, são causados. Por falta de comunicação, por falta de supervisão, por planejamento defeituoso, por erros humanos, tais como agressão, distração, fadiga, indisciplina, arrogância ou avareza. Os planejadores têm feito e estão fazendo tudo que podem para eliminar as causas físicas e ambientais. Já sabemos como eliminar os riscos, ao preparar os planos das fábricas, máquinas e processos, ao organizar os locais de trabalho e ao estruturar os métodos de trabalho. Podemos recorrer à ergonomia, para que a segurança acompanhe as máquinas e fábricas, ainda no estágio de plantas e projetos. Mas, devido ao fator humano, os acidentes continuam a acontecer [Lima, 1976: p. 67].

Três anos antes, durante o XII CONPAT, a psicóloga Eurídice Freitas já apontava para a importância da psicologia na prevenção dos acidentes:

A psicologia aplicada participa na prevenção de acidentes, quando contribui para um ajustamento mais satisfatório do homem à sua tarefa, por meio de procedimentos de informação, de seleção e de orientação profissionais; quando, pela análise das funções e cargos, pode discriminar as exigências psicofisiológicas de uma boa adaptação do ponto de vista da segurança do trabalho; quando, pela investigação, chega a um diagnóstico analítico de traços pessoais os quais, sensibilizando e predispondo o indivíduo, podem aumentar a probabilidade de acidentes [Freitas, 1974: p. 28].

A possível inovação ocorrida nesse período é clarificada por Dela Coleta (1976), relator do XV CONPAT, que afirmou terem sido superadas as idéias de um indivíduo predisposto como um todo a sofrer acidentes, as quais estavam sendo substituídas cada vez mais pela busca, não do 
trabalhador acidentável, mas de “...certas variáveis (idade, experiência, inteligência etc...) que estariam relacionadas à ocorrência de acidentes de trabalho" (p. 49).

Marina Soares Rodrigues - em sua dissertação de mestrado, defendida no Instituto de Psicologia da USP - realizou um estudo clínico com trabalhadores acidentados encaminhados ao Centro de Reabilitação Profissional do Instituto Nacional de Previdência Social, onde trabalhava como psicóloga (Rodrigues, 1984). Em seu estudo, ressuscita as explicações psicanalíticas, dadas como mortas por Szasz (1984) nos Estados Unidos na mesma época, afirmando ser o acidente a resolução de conflitos intrapsíquicos. Segundo Rodrigues (1984):

O acidente é fruto da incapacidade do sujeito para suportar a angústia e da impossibilidade de poder pensá-la. Nesse sentido, funcionaria como uma tentativa de ao injuriar o próprio corpo, conjurar a angústia que nele residia. Trata-se de um pensamento que se realiza no plano concreto e não abstrato. Estamos lidando com um ego fundamentalmente corporal. $\mathrm{O}$ corpo como sede da angústia, reduzido e restrito à função de um instrumento de trabalho e sem possibilidade de ser uma fonte de prazer e conhecimento [p. 62].

Ou ainda:

A mutilação física é a alternativa que o trabalhador recorre para se aliviar do intenso sofrimento psíquico, quando ocorre o retorno do reprimido. Quando este homem não morre, na ocasião do acidente, sentimo-nos autorizados para afirmar que o acidente de trabalho se transforma numa mensagem, a de que dentro dele ainda há esperança de ser ouvido. O que essas pessoas precisam porque não têm no seu léxico de vida, é a ternura [p. 76].

A autora também estabelece relações entre esses mecanismos psicológicos e a dificuldade de reabilitação:

O acidente de trabalho surge para o trabalhador como o único recurso que ele vislumbra para abafar a sensação de impotência; através dele a realidade externa (a Previdência) passa a suprir os cuidados que seu ego desvalido requer. A situação objetiva do trabalhador piora muito porque as seqüelas do acidente o deixam como menos recursos para enfrentar as exigências do mercado de trabalho. A "Caixa" passa a se constituir na tábua de salvação que vai suprir os recursos que seu ego não dispõe. Forma-se um ciclo vicioso porque para manter esta fonte nutriente (a Caixa) o segurado deverá acentuar a fragilidade do seu ego, realizando um contínuo ataque ao próprio corpo [p. 62].

Note-se como nessas citações a autora faz generalizações descabidas e, principalmente, reduz as explicações dos acidentes de trabalho e as dificuldades de reabilitação a fatores exclusivamente psicológicos. Ao fazer isso, tira de cena as condições de trabalho em que os acidentes ocorreram e as seqüelas deixadas por estes últimos. Assim, de forma bastante grotesca, retira os indivíduos do mundo que habitam, a "realidade externa", e entrega seus destinos à onipotência de uma pouco esclarecida realidade, digamos, "interna".

Santos (1991), ao analisar o discurso prevencionista oficial no período que vai desde a instalação do regime autoritário até a abertura democrática, aponta para a difusão dos conceitos associados à Teoria dos Dominós de Heinrich. Segundo a autora, "a prevenção oficial adotou 
uma tipologia internacional que assinala duas causas para o acidente de trabalho: 'atos inseguros' e "condições inseguras"” (p. 70). As autoridades governamentais da época encaravam a gravidade da situação acidentária brasileira como decorrência da inadaptação dos trabalhadores ao desenvolvimento industrial. Essa visão dava um maior peso aos fatores humanos produtores dos acidentes e conduziu a uma grande ênfase na formação de técnicos especializados e no treinamento dos trabalhadores. Assim, as décadas de setenta e oitenta testemunharam o crescimento vertiginoso do número de especialistas em higiene e segurança do trabalho formados segundo essa ótica. Proliferaram-se também os esforços para educar e "conscientizar" os trabalhadores, através dos cursos de formação de cipeiros e campanhas nacionais de prevenção de acidentes. A soma de tudo isso teve por conseqüência o forte enraizamento dessas concepções sobre os acidentes no imaginário social (Santos, 1991).

Poder-se-ia afirmar que, passadas algumas décadas, a conformação e importância dessas idéias poderiam ter se modificado. Realmente, na literatura científica ocorre o desaparecimento de estudos sobre fatores exclusivamente humanos causadores de acidentes, conduzidos sob os moldes das décadas anteriores. Entretanto, se ocorre seu desvanecimento na literatura científica, muitos psicólogos que prestam assessorias a empresas - assim como outros profissionais de segurança do trabalho - continuam a proliferar essa visão.

Tomemos como exemplo os relatos das experiências de uma psicóloga que assessora empresas na prevenção de acidentes por meio de técnicas comportamentais de elevação da autoestima dos trabalhadores, com a promessa de reduções drásticas nos índices de acidentes (Murakoshi, 1995). Essa psicóloga vem trabalhando para grandes empresas, nas quais realiza intervenções e apresenta palestras. Durante uma de suas palestras ${ }^{22}$ - feita a convite da Fundacentro, em 1995 - teceu considerações a respeito de um trabalhador da Cia. Nitroquímica Brasileira, que sofrera diversos acidentes:

... a pessoa que tava tendo acidentes constantes, acidentes pequenos, nós fomos investigar a vida desse sujeito, era uma pessoa que veio do nordeste, tava aqui em São Paulo sozinho, não tinha parentes, não tinha amigos e vivia num quartinho. $O$ único momento que ele tinha alguém pra conversar ou para algum contato, toque, era quando ele era acidentado. Era o único momento que ele recebia uma atenção da enfermaria, era aquele momento que ele era acidentado... [...] ...então, a gente começou a verificar que um acidente também era um canal de comunicação entre trabalhador e a empresa, era a forma de ele dizer que precisa de alguma coisa [...] Então, nós começamos a verificar que as pessoas que sofriam acidentes eram pessoas que, de alguma forma, tinha a auto-estima baixa, tinha um auto-valorização baixa. Então, porque a gente não começa a trabalhar neste sentido? Foi o que a gente fez. Agora, o que acontece? Nós temos os acidentes físicos, que são muito fáceis de se constatar, verificar, mas o que acontece antes do acidente fisico? Nós temos os acidentes emocionais.

\footnotetext{
${ }^{22}$ Palestra apresentada durante a mesa-redonda Saúde, Segurança e Qualidade de Vida no Trabalho, promovida pela Fundacentro, Fundação Jorge Duprat Figueiredo de Segurança e Medicina do Trabalho (Ministério do Trabalho), no dia 20/06/95.
} 
Salienta também o seu entendimento a respeito da responsabilidade que teria o trabalhador pela sua própria segurança:

Em geral, o trabalhador coloca a responsabilidade da segurança no setor de segurança. E não é. O setor de segurança, lógico tem uma série de coisas, de responsabilidades para tratar, mas ele não é responsável pela segurança do trabalhador, ele é responsável em dar condições, cuidar do ambiente, cuidar do maquinário, em cuidar de todo esse arsenal, mas eu sou responsável por minha própria segurança. Então, o trabalho muito grande que nós tivemos no sentido de conscientizar essa auto-segurança com a própria vida ou com a própria segurança.

Todos esses exemplos representam muito daquilo que se tem feito no interior das empresas, mas de que pouco se ouve falar. São ilustrações de práticas que acontecem cotidianamente, sem que se tome conhecimento de sua extensão. Mesmo que não sejam as práticas mais adotadas na prevenção dos acidentes, sua simples existência demonstra a presença de uma determinada maneira de encarar os acidentes que tem persistido ao longo das últimas décadas.

A conseqüência dessa forma de encarar os acidentes que, apesar de pequenas variações, conseguiu atravessar os anos mantendo adeptos fiéis, não poderia ser tão clara: impõe uma versão da realidade que descontextualiza um fenômeno social, reduzindo-o a mera manifestação psíquica ou individual daquele que é o maior prejudicado, o próprio trabalhador acidentado.

Todos esses exemplos são uma amostra de como as idéias estritamente psicológicas sobre os acidentes estão presentes em nosso contexto social e fornecem elementos para a compreensão dos acidentes de trabalho. Se voltarmos nosso olhar para as produções discursivas do dia-a-dia, o que encontraremos? Como as concepções herdadas da acidentologia e das "ciências do comportamento" contribuem na construção discursiva do acidente de trabalho? Como as idéias psicologizantes sobre os acidentes presentes na cultura são negociados no interior das fábricas? como conseguiram persistir? Como são desafiadas? São essas e outras perguntas que orientaram o estudo de caso realizado, que apresentamos a seguir. 


\section{O ACIDENTE DE TRABALHO NO COTIDIANO: ESTUDO DE CASO DE EMPRESA METALÚRGICA}

O objetivo deste capítulo é investigar como os significados dos acidentes de trabalho, através dos discursos e das práticas, são construídos no dia-a-dia de uma indústria. Nesse processo de revirar aquilo que é dito e feito a respeito dos acidentes, supõe-se que, por um lado, as concepções em circulação em nosso meio social e, por outro, as pressões locais, determinem o conteúdo e o uso dos repertórios interpretativos construídos com a finalidade de dar significado ao fenômeno. Como ficará claro no decorrer da apresentação, esses repertórios não são um corpo coerente de explicações, mas, antes, comportam aspectos dilemáticos e a presença de diferentes vozes.

O caso estudado foi uma empresa metalúrgica de grande porte localizada em uma região industrializada da Grande São Paulo. A escolha dessa empresa, com base em critérios já mencionados, foi antecedida pela exploração prévia da região à qual pertence - por meio de dados secundários e questionário exploratório ${ }^{23}$ respondido por operários de diferentes empresas - e contatos com diretores do sindicato de trabalhadores metalúrgicos.

A referida região abrange 12 municípios da Grande São Paulo, que juntos abrigam 600 mil habitantes, dentre os quais encontram-se 40 mil trabalhadores empregados em empresas do ramo metalúrgico.

O conjunto desses operários constitui a população base do sindicato da região, o qual tem uma história de lutas, que inclui a resistência à ditadura militar e a identificação com o chamado "novo sindicalismo", surgido no início dos anos oitenta. A entidade tem um considerável nível de sindicalização e mantém em algumas empresas da região (dentre elas a empresa-caso) diretores de base, isto é, representantes sindicais que permanecem em seu trabalho de origem e procuram organizar o movimento no interior das fábricas. As posições do sindicato em relação à saúde dos trabalhadores afinam com aquelas adotadas pelo Departamento Intersindical de

\footnotetext{
${ }^{23}$ A análise das respostas ao questionário exploratório (para detalhes, ver o anexo a), utilizado como primeira aproximação aos repertórios interpretativos, revelou um número considerável de causas atribuídas aos acidentes, bem como de propostas de prevenção. Apontou também para uma predominância significativa de concepções centradas nos aspectos humanos dos acidentes, tanto para a explicação de suas causas, quanto para as medidas preventivas sugeridas. Resultado semelhante foi obtido por Binder \& cols. (1994) em análise de atas de reuniões de CIPA de três empresas metalúrgicas da Grande São Paulo. Embora esse instrumento tenha fornecido pistas sobre o que seria encontrado em campo, ele não foi capaz de revelar determinados aspectos dos discursos - como, por exemplo, a argumentação - importantes para a análise que se pretendia empreender.
} 
Estudos em Saúde e Ambientes de Trabalho (Diesat) - órgão não vinculado a centrais sindicais que assessora diversos sindicatos do país e foi pioneiro na consolidação de uma perspectiva sindical crítica a respeito das questões de saúde e trabalho. Assim, os representantes dos trabalhadores da empresa-caso assumem o enfoque sindical para os acidentes de trabalho discutido no capítulo anterior, de modo que são críticos das concepções centradas nos fatores humanos e adotam uma perspectiva mais global de compreensão do fenômeno, vislumbrando seus aspectos sociais e políticos.

A análise das 1.372 Comunicações de Acidentes de Trabalho ${ }^{24}$ registradas na região durante o ano de 1995, embora não se possa estimar a subnotificação existente, oferecem um retrato aproximado do número e dos tipos de acidentes que têm acometido a categoria. Os dados revelaram que 78,94\% das comunicações referiam-se a acidentes de trabalho típicos. Segundo as partes do corpo atingidas, encontrou-se a seguinte distribuição: membros superiores $(59,56 \%)$, membros inferiores $(18,28 \%)$, cabeça $(6,83 \%)$, tronco $(4,80 \%)$, olhos $(4,06 \%)$, outras partes do corpo $(5,08 \%)$.

A seguir são apresentados os achados do trabalho de campo. Quando necessário, a apresentação sucinta dos dados foi entremeada por descrições detalhadas dos acontecimentos vivenciados, de modo a permitir construir um quadro denso da realidade estudada e fornecer ao leitor elementos para que possa conhecer os caminhos percorridos pela análise. Inicialmente é feita uma descrição geral da empresa e das práticas institucionalizadas de enfrentamento dos acidentes de trabalho. Em seguida, são analisadas as práticas discursivas e as relações entre os repertórios interpretativos disponíveis no contexto da empresa-caso.

\subsection{A empresa-caso: processo de trabalho, riscos e acidentes}

A Metalco, como será designada a empresa-caso de agora em diante, é do ramo de autopeças e emprega 1.500 pessoas. Seus principais produtos são conjuntos mecânicos pesados para veículos motorizados ${ }^{25}$. A maioria das peças que compõem esses conjuntos são produzidas na própria empresa, as restantes são compradas de terceiros.

São quatro os principais processos de transformação de matéria-prima desenvolvidos: forja, usinagem, retífica e montagem. Os três primeiros dizem respeito à transformação gradativa

\footnotetext{
${ }^{24}$ A Comunicação de Acidentes do Trabalho (CAT) é um documento do INSS, para fins previdenciários, de registro compulsório de acidentes ou doenças do trabalho. As empresas são obrigadas a emiti-las e enviar cópias para o INSS, a Delegacia Regional do Trabalho, o sindicato da categoria e o próprio acidentado. Os dados apresentados foram fornecidos pelo sindicato de trabalhadores da região.
} 
do aço em peças de precisão que serão, finalmente, reunidas durante o processo da montagem e comporão os conjuntos mecânicos pesados a serem comercializados. Na forja, o aço, que chega em forma de barras, é cortado, aquecido em fornos e prensado ou martelado para adquirir a forma bruta da peça. Na usinagem, as peças recém forjadas são desbastadas, furadas, rosqueadas. $\mathrm{Na}$ retificação, é dado o acabamento final e as peças seguem para a montagem.

O setor de produção está espalhado por grandes galpões com pé direito duplo e telhado de zinco. O interior de cada um deles subdivide-se em quadras separadas por ruas estreitas que permitem a circulação de empilhadeiras - transportando matéria-prima ou produtos acabados - e funcionários. Diversos tipos de máquinas (tornos, prensas, furadeiras, retíficas etc.) espalham-se por essas quadras, incluindo máquinas de última geração, como furadeiras e tornos automáticos (que realizam sozinhos e sob a supervisão de uma pessoa, as operações que anteriormente eram feitas por diversos operários) e máquinas muito antigas (algumas da década de 50).

Existe hoje na empresa uma tendência para a renovação de suas instalações, que é acompanhada por uma outra tendência, a de redução de postos de trabalho (acentuada em função da retração das vendas no mercado interno e a conseqüente queda de produção). Essas tendências antagônicas vêm preocupando trabalhadores e sindicalistas que reconhecem a importância da renovação para a garantia de maior segurança no trabalho, mas, ao mesmo tempo, temem as demissões acarretadas por essas mesmas mudanças.

Diversos são os riscos para acidentes na empresa-caso. Embora não tenha sido o objetivo desta pesquisa fazer um levantamento detalhado de tais riscos, pode-se listar aqueles que são mais evidentes e mais comentados por todos na empresa. Os riscos começam na manipulação das peças e produtos acabados, que ocasionam prensamentos nas mãos (pois muitas peças pesam mais de 30 quilos) ou queimaduras, no caso das peças fundidas ou recém soldadas. $\mathrm{O}$ transporte e armazenamento também apresentam os mesmos riscos. As máquinas oferecem os riscos mais graves, principalmente nas ações de ajuste, limpeza, manutenção, alimentação ou operação, durante as quais o contato com a máquina ou as peças em movimento, cantos vivos, rebarbas ou cavacos pode ocasionar lesões.

Quanto aos acidentes de trabalho, esses são classificados pela empresa, em função de sua gravidade, em 4 tipos:

Acidente leve: acidente que é atendido na própria enfermaria da empresa, sem a necessidade de encaminhamento para o convênio médico, de afastamento ou de mudança temporária da atividade desempenhada;

\footnotetext{
${ }^{25}$ Optou-se por uma designação genérica para os produtos, com a finalidade de dificultar a identificação da Metalco.
} 
Acidente sem afastamento e sem restrição: acidente que requer atendimento que não pode ser prestado na enfermaria ou que necessita da palavra de um clínico para avaliar a sua gravidade;

Acidente sem afastamento e com restrição: acidente onde a lesão é tal que impede que o trabalhador continue desempenhando sua atividade normal, mas que não o impediria de realizar outros tipos de tarefas mais leves, que não dificultariam a recuperação de sua saúde;

Acidente com afastamento: acidente onde a lesão é de tal gravidade ou impõe tal limitação física que não permite ao trabalhador desempenhar a sua atividade de costume nem qualquer outra atividade dentro da empresa. Esses são os acidentes mais graves.

A equipe de segurança refere-se a uma diminuição, nos últimos anos, dos acidentes leves e a um aumento proporcional dos acidentes com afastamento. Essas tendências podem ser observadas na tabela a. Diversas explicações foram levantadas pelos técnicos para dar conta do fenômeno, as quais serão discutidas adiante.

Tabela A: Freqüência anual de acidentes por gravidade - Metalco, 1993 a 1995.

\begin{tabular}{|c|c|c|c|}
\hline Acidentes por gravidade & 1993 & 1994 & 1995 \\
\hline Acidentes com afastamento & 22 & 43 & 37 \\
\hline Acidentes sem afastamento (com ou sem restrições) & 102 & 122 & 111 \\
\hline Acidentes leves & 137 & 103 & 62 \\
\hline Totais & 261 & 268 & 210 \\
\hline
\end{tabular}

Fonte: Metalco.

Quanto ao número total de acidentes por ano, embora tenha havido uma diminuição entre os anos de 1993 e 1995, ela não significa uma diminuição correspondente da incidência relativa de acidentes, pois, como revela a tabela $b$, houve no mesmo período uma diminuição do número de funcionários e de horas trabalhadas. $\mathrm{Na}$ verdade, a taxa de acidentes em geral manteve-se estável no período estudado, ao mesmo tempo que se observou aumentos do índice de acidentes com afastamento e do índice de gravidade desses acidentes (tabela b). 
Tabela B: Taxas relacionadas à acidentabilidade - Metalco, 1993 a 1995.

\begin{tabular}{|l|c|c|c|}
\hline \multicolumn{1}{|c|}{ Taxas relacionadas à acidentabilidade } & $\mathbf{1 9 9 3}$ & $\mathbf{1 9 9 4}$ & $\mathbf{1 9 9 5}$ \\
\hline Média anual de funcionários & $2.215,58$ & $2.288,75$ & $1.994,83$ \\
\hline Horas trabalhadas & 5.192 .592 & 5.209 .431 & 4.288 .830 \\
\hline Taxa de incidência de acidentes & 50,26 & 51,44 & 48,96 \\
\hline Taxa de freqüência de acidentes com afastamento & 4,24 & 8,25 & 8,63 \\
\hline Taxa de gravidade de acidentes com afastamento & 36,01 & 155,49 & 153,89 \\
\hline
\end{tabular}

Fonte: Metalco.

Feita a descrição sucinta da Metalco, seus riscos e acidentes, passa-se para a discussão das ações preventivas adotadas pela equipe de segurança e da atuação da CIPA.

\subsubsection{Análise de acidentes, eliminação de riscos e "conscientização" dos trabalhadores}

O setor de segurança do trabalho conta com um engenheiro, cinco técnicos de segurança e está subordinado à direção de recursos humanos. Essa equipe é responsável, entre outras coisas por: inspeções de rotina da fábrica, identificação de riscos à saúde, fornecimento de Equipamentos de Proteção Individual (EPI), registro e análise dos acidentes ocorridos, elaboração de campanhas de prevenção de acidentes, assessorias prestadas à CIPA, organização de palestras, organização de cursos para novos cipeiros.

Todos os acidentes ocorridos na empresa são registrados e analisados em uma ficha de acidentes elaborada pela equipe de segurança. Essa ficha abrange informações gerais sobre o acidentado, sobre a lesão sofrida e a descrição do acidente. Quanto a esta última, há três campos principais: descrição propriamente dita, condições inseguras presentes e atos inseguros cometidos. Há também um campo complementar onde o próprio acidentado declara a razão pela qual praticou ato inseguro, se for o caso.

A ficha possui, ainda, cinco campos para codificação das seguintes informações: tipo de acidente, agente da lesão, condição insegura, ato inseguro e fator pessoal ${ }^{26}$.

Foram analisadas 250 fichas contendo análises de acidentes, preenchidas durante o ano de 1995 $5^{27}$. Desses acidentes, 98 foram explicados pela concorrência simultânea de condições inseguras e atos inseguros ou fatores pessoais, a 81 acidentes foram atribuídos como causas

\footnotetext{
${ }^{26}$ Note-se a sobreposição entre "ato inseguro" e "fator pessoal".

27 Ao todo foram preenchidas 312 fichas em 1995, das quais, 29 referiam-se a doenças ocupacionais (em geral lesões por esforços repetitivos ou perda auditiva), 28 a acidentes de trajeto e 250 a acidentes típicos.
} 
exclusivas os atos inseguros ou fatores pessoais, os outros 7 acidentes foram considerados como tendo unicamente como causa as condições inseguras e 64 não foram classificados.

As condições inseguras que - segundo a classificação previamente definida na ficha de análise de acidentes ${ }^{28}$ e assinaladas pelos técnicos - contribuíram para a produção dos acidentes foram as seguintes: “defeito na máquina, no equipamento, na edificação etc”; "má arrumação de espaço, mau empilhamento"; "máquina ou equipamento com proteção inadequada"; "falta de proteção individual"; "Falta de proteção na máquina ou equipamento". A distribuição de cada uma dessas categorias encontra-se na tabela c.

Tabela C: Condições inseguras presentes, segundo a análise dos técnicos de segurança, nos acidentes do ano de 1995

\begin{tabular}{|c|c|c|}
\hline Condição insegura & Freq. & $\%$ \\
\hline Defeito na máquina, no equipamento, na edificação etc. & 40 & 21,50 \\
\hline Má arrumação de espaço, mau empilhamento & 14 & 7,53 \\
\hline Máquina ou equipamento com proteção inadequada & 10 & 5,38 \\
\hline Falta de proteção individual & 4 & 2,15 \\
\hline Falta de proteção na máquina ou equipamento & 1 & 0,54 \\
\hline Outras & 36 & 19,35 \\
\hline Não houve condição insegura & 81 & 43,55 \\
\hline Total & 186 & $100 \%$ \\
\hline
\end{tabular}

Fonte: Fichas de registro e análise de acidentes, Metalco.

Por sua vez, foram eleitas pelos mesmos técnicos de segurança as seguintes categorias de atos inseguros ${ }^{29}$ que contribuíram para a ocorrência dos acidentes analisados (conforme a tabela d): "colocar-se, ou parte do corpo, em posição ou local perigoso"; "carregar ou dispor materiais de maneira insegura"; "usar ferramentas inadequadas, em más condições ou as mãos como ferramentas"; "distrair-se, brincar, abusar do perigo"; "deixar de usar equipamento de proteção individual"; "trabalhar com dispositivo de segurança neutralizado ou deturpado"; "operar em

\footnotetext{
${ }^{28}$ Segundo a ficha: "Condições inseguras (condições físicas e/ou mecânicas que comprometem a segurança do trabalhador): Máquina ou equipamento com proteção inadequada; Defeito na máquina, no equipamento, na edificação, etc.; Má arrumação de espaço, mau empilhamento; lluminação inadequada; Ventilação inadequada; Falta de proteção na máquina ou equipamento; Falta de proteção individual".

${ }^{29}$ Segundo a ficha: "Atos inseguros (atos através dos quais as pessoas se expõem a riscos de acidentes): Operar em máquina ou outros equipamentos sem habilitação ou autorização; Trabalhar com excesso de velocidade ou sobrecarga; Trabalhar com dispositivo de segurança neutralizado ou deturpado; Usar ferramentas inadequadas, em más condições ou as mãos como ferramentas; Carregar ou dispor materiais de maneira insegura; Manipular, misturar produtos químicos de modo impróprio; Colocar-se, ou parte do corpo, em posição ou local perigoso; Limpar, lubrificar, ajustar, etc. máquinas em movimento; Distrair-se, brincar, abusar do perigo; Deixar de usar equipamento de proteção individual; Usar roupa inadequada, pulseiras, anéis, etc.".
} 
máquinas ou outros equipamentos sem habilitação ou autorização"; "limpar, lubrificar, ajustar etc. máquinas em movimento".

Tabela D: Atos inseguros cometidos, segundo a análise dos técnicos de segurança, pelos trabalhadores envolvidos nos acidentes do ano de 1995

\begin{tabular}{|l|c|c|}
\hline \multicolumn{1}{|c|}{ Ato inseguro } & Freq. & \% \\
\hline Colocar-se, ou parte do corpo, em posição ou local perigoso & 57 & 30,64 \\
\hline Carregar ou dispor materiais de maneira insegura & 44 & 23,66 \\
\hline $\begin{array}{l}\text { Usar ferramentas inadequadas, em más condições ou as mãos como } \\
\text { ferramentas }\end{array}$ & 20 & 10,76 \\
\hline Distrair-se, brincar, abusar do perigo & 16 & 8,60 \\
\hline Deixar de usar equipamento de proteção individual & 10 & 5,38 \\
\hline Trabalhar com dispositivo de segurança neutralizado ou deturpado & 5 & 2,69 \\
\hline $\begin{array}{l}\text { Operar em máquinas ou outros equipamentos sem habilitação ou } \\
\text { autorização }\end{array}$ & 2 & 1,07 \\
\hline Limpar, lubrificar, ajustar etc. máquinas em movimento & 2 & 1,07 \\
\hline Outros & 7 & 3,76 \\
\hline Não Houve ato inseguro ${ }^{30}$ & 186 & $100 \%$ \\
\hline
\end{tabular}

Fonte: Fichas de registro e análise de acidentes, Metalco.

Sobrepondo-se aos atos inseguros, também foram apontados fatores pessoais que tiveram relação com a produção do acidente, agrupados nas seguintes categorias ${ }^{31}$ : "má interpretação do perigo"; "atitude imprópria - incluem-se motivos psicológicos"; "desconhecimento do risco"; "negligência"; "conhecimento ou treinamento insuficientes" (tabela e).

\footnotetext{
${ }^{30}$ A 16 desses acidentes foram atribuídos fatores pessoais.

31 Segundo a ficha: "Fatores pessoais (Falhas inerentes à pessoa como tal ou como trabalhador): Desconhecimento do risco; Má interpretação do perigo; Conhecimento ou treinamento insuficientes; Atitude imprópria - incluem-se motivos psicológicos; Defeito físico ou incapacidade física para o trabalho; Negligência".
} 
Tabela E: Fatores pessoais que, segundo a análise dos técnicos de segurança, tiveram relação com os acidentes do ano de 1995

\begin{tabular}{|c|c|c|}
\hline Fator pessoal & Freq. & $\%$ \\
\hline Má interpretação do perigo & 68 & 36,56 \\
\hline Atitude imprópria - incluem-se motivos psicológicos & 55 & 29,57 \\
\hline Desconhecimento do risco & 23 & 12,37 \\
\hline Negligência & 18 & 9,67 \\
\hline Conhecimento ou treinamento insuficientes & 4 & 2,15 \\
\hline Outros & 4 & 2,15 \\
\hline Nenhum fator pessoal contribuiu para o acidente ${ }^{32}$ & 14 & 7,53 \\
\hline Total & 186 & $100 \%$ \\
\hline
\end{tabular}

Fonte: Fichas de registro e análise de acidentes, Metalco.

Quanto ao tipo de respostas dos trabalhadores para a pergunta: "por que cometeu ato inseguro?", encontrou-se desde as que admitiam a existência desses atos até aquelas que recusavam essa explicação e denunciavam condições de trabalho inadequadas que teriam levado ao acidente.

A Teoria dos Dominós de Heinrich, que dá a tônica aos procedimentos de análise de acidentes, deixa-se transparecer na ficha de registro através dos conceitos de atos inseguros e condições inseguras. Seu uso institucionalizado tem como conseqüência a restrição das possibilidades de compreensão dos acidentes, pois conduz a investigação aos antecedentes imediatos e sua presença na ficha exige que se tenha presente no contexto explicativo do acidente a possibilidade de existência de atos inseguros, instaurando e, em uma certa medida, perpetuando uma determinada versão da realidade.

Dentre as ações diretamente voltadas para prevenção de acidentes, que costumam ser realizadas pela equipe de segurança, devem-se destacar a adaptação de proteções em máquinas que ainda não disponham desse recurso, a instalação de talhas e balancins para a manipulação de peças e conjuntos mecânicos pesados (evitando prensamentos de dedos e problemas ósteomusculares).

Quanto aos EPIs, são fornecidos aos operários: capacetes, protetores auriculares, óculos de segurança, luvas, uniformes, sapatos de segurança, dentre outros. O seu uso é bastante difundido entre os trabalhadores, embora a equipe de segurança e os cipeiros queixem-se que alguns ainda se recusam a usá-los. Vale lembrar que esses equipamentos são um tema

\footnotetext{
${ }^{32}$ A sete desses acidentes foram atribuídos atos inseguros.
} 
controvertido. Em muitos casos, seu uso não previne acidentes, mas apenas diminui a gravidade das lesões. Além disso, eles podem ser inadequados para o tipo de tarefa realizada e sua utilização constante pode causar incômodo.

A detecção de riscos é papel tanto da equipe de segurança, quanto dos cipeiros e dos operários em geral (há mesmo uma ênfase na participação dos operários nessa atividade, os quais são incentivados a comunicar problemas no ambiente de trabalho tão logo os encontrem, embora, como veremos adiante, essas ações envolvam diversos conflitos que dificultam sua efetivação). Há um acompanhamento mensal pela CIPA dos riscos levantados, eliminados e pendentes, isto é, que foram identificados em meses anteriores mas ainda não foram eliminados (ver gráfico b).

Gráfico B: Programa de Prevenção de Riscos Ambientais, Metalco: distribuição de riscos levantados, resolvidos e pendentes durante o período de julho de 1995 a junho de 1996.

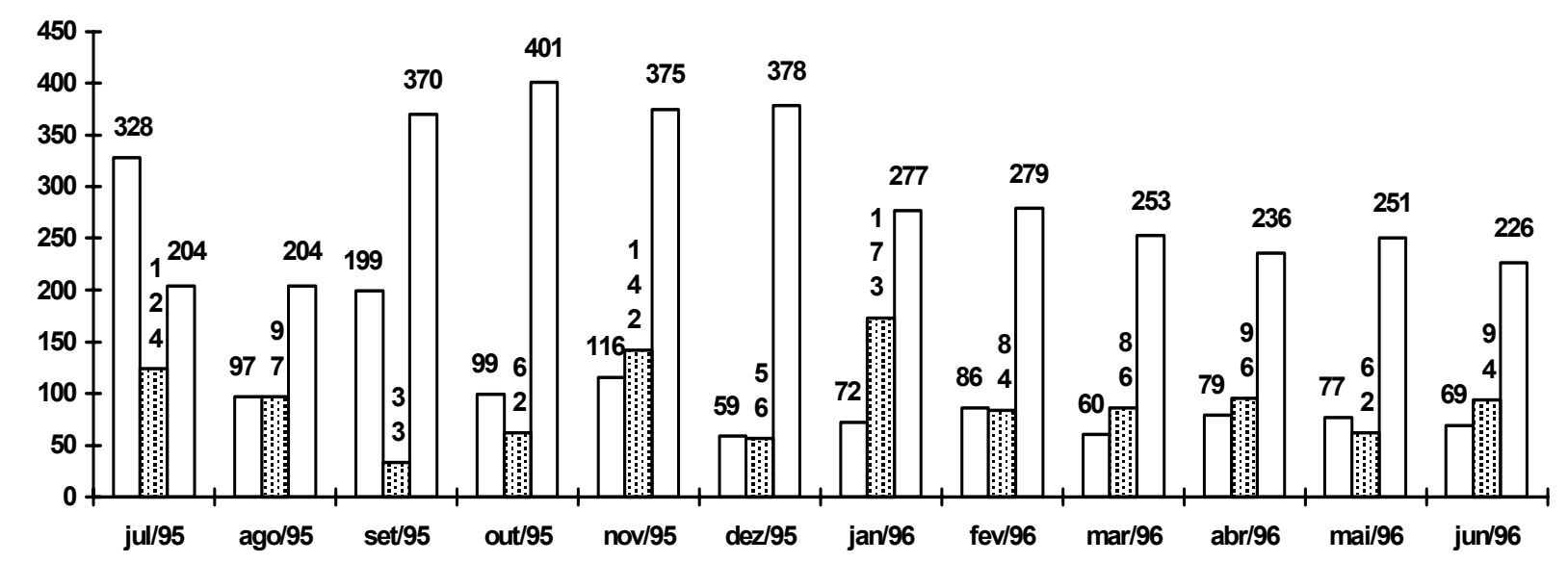

Fonte: Metalco.

Em muitos depoimentos encontraram-se comparações entre a situação da Metalco há anos atrás e sua situação atual. Quase todos se referiram a maiores investimentos em segurança, maior preocupação com a prevenção de acidentes - expressa nas correções ambientais e nas práticas de conscientização. Um entrevistado falando sobre um acidente que sofreu refere-se a essa mudança:

Mas também foi o único, né, de lá pra cá a empresa investiu também muito em combate a acidente, né, antigamente era... a gente levava de qualquer jeito, né, tava nem aí com acidente, melhorou muito de um certo tempo, isso aí a gente não tem que reclamar porque é... o que a Metalco investiu em combate a acidente... [Caetano ${ }^{33}$, operador de máquina, entrevista 3]

Além das mudanças ambientais, como instalação de equipamentos mais modernos e de proteções em máquinas, muitos entrevistados enfatizaram as mudanças comportamentais

\footnotetext{
${ }^{33}$ Todos os nomes dos entrevistados são fictícios.
} 
ocorridas - por exemplo, os trabalhadores teriam passado a tomar maior cuidado para evitar acidentes e a usar EPI com maior freqüência - como sendo as mais importantes:

Bom, pobrema de acidente, sei lá, né, é uma coisa relativa, né? [Pausa] É... como eu te falei, que o pessoal tá se conscientizando faz pouco tempo, que a qualidade é a mesma coisa com o acidente de trabalho. Porque aqui o pessoal trabalhava de qualquer jeito, não usava óculos, não usava protetor, isso quando eu entrei aqui, tá... [Edvaldo, inspetor de qualidade, entrevista 5].

Um outro conjunto de ações engloba aquelas voltadas para informar, educar, "conscientizar" os trabalhadores e modificar seus comportamentos em relação à segurança no trabalho. Incluem-se aqui campanhas, cartazes, cartilhas, semanas de prevenção, cursos, palestras semanais. Essas ações ocupam um espaço importante na imagem que os técnicos fazem de seu próprio trabalho, pois, quando perguntados sobre o que têm feito no campo da prevenção, são essas as primeiras coisas a que se referem e as que recebem maior destaque. Dada sua importância na tentativa de perpetuação de uma certa versão sobre os acidentes de trabalho, essas ações serão exemplificadas e discutidas em uma seção específica, adiante.

\subsubsection{A atuação da CIPA: correções ambientais e ação disciplinar}

A atual gestão da CIPA reúne cipeiros eleitos que, nos últimos dois anos, modificaram positivamente a imagem dessa comissão perante todos na empresa ${ }^{34}$. Ela também é muito bem vista pelo sindicato, que a tem como modelo. São ao todo 18 membros, dos quais 9 são cipeiros eleitos pelos trabalhadores e 9 cipeiros indicados pela direção da empresa. Os suplentes dos cipeiros eleitos também participam das reuniões e têm papel ativo nas atividades de segurança.

Dentre as suas principais conquistas, estão o plano de ação apresentado anualmente para a empresa, um jornal próprio de circulação interna e o acompanhamento sistemático da eliminação ou controle dos riscos identificados na empresa. Trata-se de uma CIPA realmente ativa, que não existe apenas para cumprir os ditames da lei e que, dentro dos limites das concepções sobre os acidentes majoritárias na Metalco, busca soluções criativas e efetivas para os problemas com que se deparam no dia-a-dia.

Sua atuação será exemplificada com o relato de uma de reunião ordinária mensal. Devese notar que a CIPA, por reunir operários eleitos e encarregados indicados, não é um grupo homogêneo - o que se reflete nas diferentes posturas assumidas por essa comissão. A análise apresentada a seguir prioriza justamente as contradições entre o espírito combativo de seus membros eleitos e a reprodução de concepções culpabilizantes. 
No início da reunião, a penúltima da gestão, o presidente da CIPA (que é um membro indicado pela direção da empresa) apresentou o pesquisador aos outros cipeiros. Comentou sobre a pesquisa, convidou os presentes a colaborar e disse:

a gente não sabe se é através de campanha ou de gincanas, a gente não sabe muito bem o que fazer e esta pesquisa do Fábio vai poder ajudar a gente a entender melhor como prevenir os acidentes (Presidente da CIPA).

$\mathrm{Na}$ declaração acima, fica clara a expectativa desse presidente de CIPA em relação à pesquisa e deixam-se transparecer algumas de suas hipóteses quanto à solução dos problemas de segurança, que contemplam apenas intervenções sobre o comportamento dos operários.

Dentre os assuntos pendentes - excepcionalmente, não foram discutidos riscos ambientais durante esta reunião - o transporte interno com empilhadeiras foi um tema que deu margem a uma grande discussão. Um dos cipeiros eleitos disse que teve problemas com um operador de empilhadeira do período da noite, depois de tê-lo denunciado por não usar óculos de proteção nem protetor auricular durante a condução do veículo. O presidente disse: "o cara é um ignorante, não dá nem pra levar em consideração", caracterizando-o como um criador de problemas com o qual seria difícil dialogar. Um outro cipeiro disse que era comum entre os operadores de empilhadeira do período noturno não usar os referidos equipamentos de proteção. Um encarregado presente disse que a solução seria o cipeiro, ao constatar a irregularidade, anotar o número da empilhadeira e passá-lo à chefia competente. Um outro cipeiro lembrou que faltavam empilhadeiras à noite e que isso deveria ser cobrado de um dos encarregados, já que era ele o responsável pela distribuição dos operadores de empilhadeiras. O presidente disse que essa dificuldade advinha da extinção do segundo turno no setor, o que acarretaria uma carga maior de trabalho.

Mais adiante, o presidente prosseguiu comentando a fala de um cipeiro sobre a imprudência dos operadores em questão:

esse pessoal [os operadores de empilhadeiras] tem hora que dá um 'de repente' neles e parece que vira o Senna e o cara sai correndo [...] e mesmo quando a produção tá tranqüila e não tem ninguém cobrando eles fazem assim. A mesma coisa com o equipamento de proteção... [presidente da CIPA].

Note-se que nessa fala a hipótese de pressão por produção para explicar o excesso de velocidade praticado pelos operadores é refutada, ao mesmo tempo que se atribui esse comportamento a uma causa psicológica, não compreensível e, principalmente, com motivações exteriores à empresa.

\footnotetext{
${ }^{34}$ Parte dos antigos membros foram reeleitos para nova gestão de 1996, garantindo a continuidade do trabalho que
} 
Um outro cipeiro falou de um trabalhador que não usava os óculos de proteção e que ao ser advertido "criou uma indisposição de conversar". O presidente acrescentou: "Ah, mas esse aí é um 'calo'!’. Dentre os outros cipeiros, uma voz: “É, não aceita ordem... é abusado demais". O técnico de segurança do trabalho presente disse que em casos assim deveria ser solicitada ao técnico de segurança uma inspeção de segurança, dando uma conotação punitiva a essa ação.

Um cipeiro eleito fez um contraponto às acusações e medidas punitivas propostas, afirmando que o funcionário em questão “... é um chefe de família...” e que por isso deveria terse cautela e ponderação ao tomar medidas que pudessem prejudicá-lo. Demonstrava sua preocupação com a preservação do emprego daquele trabalhador.

Um dos encarregados presentes propôs que as palestras de cinco minutos fossem usadas como um espaço para falar aos operadores de empilhadeiras sobre os cuidados a tomar na condução dos veículos, em sua opinião, seria uma forma de “... ficar pegando no pé deles, falar do chão escorregadio...”. O presidente comentou a proposta dizendo que um dos encarregados fazia exatamente isso: anotava durante a semana os problemas que observava e divulgava-os aos operários durante as palestras de segurança: “...assim, o pessoal tá bem treinado, bem informado. O problema é mesmo, assim, o pessoal 'sair da linha"”.

Dois incidentes com um mesmo operador de empilhadeiras foram comentados. $\mathrm{O}$ primeiro, aconteceu quando esse trabalhador deu marcha à ré e bateu em uma divisória, que por sua vez derrubou um vidro que quase atingiu outro operário. O segundo foi uma derrapagem em piso molhado, causada pela alta velocidade com que dirigia, que levou o veículo a esmagar uma maca de emergência do corredor em que houve o incidente. Em meio à concordância a respeito da imprudência do operador, surgiu uma voz que disse que o pessoal da limpeza havia deixado sabão na referida rampa na noite anterior ao segundo incidente relatado, o que teria contribuído para sua ocorrência. Com relação a isso foram feitas afirmações que não ficaram esclarecidas: o técnico de segurança disse que havia uma ordem expressa para que aquela rampa não fosse lavada, enquanto um cipeiro eleito afirmou: "Mas não existe uma ordem pra justamente lavar essa rampa por causa do óleo que cai e deixa escorregadio?".

O presidente reafirmou então a necessidade de treinamento para a segurança, objetivando mudar a atitude dos operadores. Propôs a apresentação de filmes e palestras para “... torná-los [os operadores de empilhadeira] novamente conscientes".

A análise do encaminhamento desse problema com o transporte interno revela um aspecto importante da atuação da CIPA. Independentemente da propriedade com que são feitas 
as intervenções junto aos trabalhadores e do valor que têm até mesmo para a segurança de outros operários, elas têm um caráter forçosamente disciplinar, isto é, de controle do comportamento e das ações dos trabalhadores, de vigilância e correção. Os operadores de empilhadeira são julgados pelo seu comportamento - o qual, diga-se de passagem, não tem na visão dos presentes relação alguma com o trabalho - e são alvo de medidas de segurança que antes de tudo visam impor-lhes um comportamento "mais adequado". Pela recusa a utilizar os equipamentos de proteção e por não seguirem as normas de segurança, são tachados de causadores de problemas. Assim, para ser alguém preocupado com a saúde, o trabalhador que é cipeiro passa a ser um disciplinador dos seus companheiros.

Por outro lado, e isto é ainda mais interessante, esses problemas com o comportamento dos operários, mesmo sendo considerados "fatores de risco" para todos os trabalhadores, não entram como itens de modificações propostas pela CIPA, pois da lista de problemas pendentes relatada na ata dessa reunião, absolutamente todos referiam-se a correções ambientais. Se ainda não está claro o significado dessa ausência, uma coisa é certa: uma análise exclusivamente voltada para as atas de CIPA dessa empresa não seria capaz de fornecer à pesquisa as informações encontradas na observação da reunião.

Ao comentar um antigo projeto de fazer um filme sobre os acidentes que aconteciam na Metalco, o presidente disse: "porque a pessoa acha que acidente só acontece nas outras empresas ou nos filmes que a gente mostra, lá fora... é pra mostrar pra elas que tem aqui dentro também tem acidente". Nessa fala, há a suposição de que as pessoas comportam-se imprudentemente por acharem que os acidentes não vão acontecer, que eles só aconteceriam em outros lugares.

Um cipeiro eleito fez uma reclamação: incidentes ${ }^{35}$ estavam acontecendo, mas não estavam sendo registrados como ocorrências. Citou o exemplo de um incidente, no qual um chicote de uma máquina escapara, voara 30 metros e quase atingira um trabalhador. Ciente da importância da análise dos incidentes para a prevenção de acidentes, disse: "Se o pessoal não tivesse comentado com a gente, a gente nem sabia". Comenta que nem o técnico de segurança ficou sabendo e que “... às vezes o 'cara' não quer se manifestar por medo [...] a chefia tá precisando dar uma força pra nós".

O presidente, diante do exposto, retomou a questão da falta de comunicação dentro da empresa: "O problema de comunicação nessa empresa é crônico. Até se você for deixar um recado para o [diretor geral], é capaz dele receber só no ano que vem”.

\footnotetext{
${ }^{35}$ Acidentes sem vítimas ou acidentes impessoais.
} 
Durante um intervalo, um cipeiro disse que o pesquisador estava presenciando algo bastante incomum em outras empresas: as pessoas poderem discutir abertamente os problemas e poderem dar respostas umas às outras; continuou dizendo que em muitas empresas os cipeiros fingiam não haver problemas e ficavam discutindo amenidades. Algumas pessoas, também, vieram comentar sobre as brigas e dizer para que o pesquisador não se assustasse. Outras pessoas comentaram sobre a imagem positiva que tinham daquela gestão da CIPA, a qual seria em sua opinião uma das melhores que já existiram na Metalco. O presidente comentou que há alguns anos atrás a empresa não tinha interesse em melhorar as condições de trabalho e "fazia vistas grossas" para os problemas, mas que hoje a direção da empresa está realmente disposta a conversar e investir em segurança.

$\mathrm{Na}$ volta do intervalo, passou-se ao levantamento de novos itens a serem introduzidos na lista de propostas da CIPA, em geral, sugeridos pelos cipeiros eleitos. Depois desse levantamento, partiu-se para a discussão dos itens que ainda estavam pendentes até a última reunião.

Em síntese, três pontos destacaram-se da observação da reunião. Primeiro, a observação da ação disciplinar da comissão, da ênfase sobre o comportamento dos operários (característica também observada por Santos, 1991) e do caráter pontual das correções ambientais. Segundo, a constatação de que as atas de CIPA não expressam fielmente o conjunto de todas as preocupações de seus membros, já que os problemas relacionados ao comportamento dos trabalhadores não são registrados como itens a serem modificados. A quantificação dos itens registrados em ata levaria à imagem de que apenas as condições ambientais estariam preocupando a comissão - e estão, como mostra o gráfico b acima ${ }^{36}$ - mas a observação da reunião revelou outras preocupações com que se ocupam os cipeiros. Assim, se temos uma CIPA que se empenha por realizar correções ambientais (diferentes de transformações que atingem o processo de trabalho profundamente), por outro lado, uma parte importante de seus esforços está dirigido para os fatores pessoais identificados como causadores de acidentes. Terceiro, as propostas de correção ambiental partiam muito mais dos cipeiros eleitos do que dos indicados; esses últimos estavam presentes apenas para avaliar as possibilidades de execução das propostas apresentadas. Quanto às queixas comportamentais, embora alguns cipeiros eleitos tenham feito declarações desse tipo - suas posições são ambíguas quanto a esse aspecto - as frases mais enfáticas vieram de encarregados indicados como cipeiros.

\footnotetext{
${ }^{36}$ No mês que precedeu a reunião, foram eliminados 86 riscos ambientais, dentre os 60 novos riscos identificados e os 279 remanescentes dos meses anteriores.
} 
A Metalco é uma empresa que - como a maioria das empresas de grande porte pertencentes ao ramo metalúrgico - tem um número significativo de acidentes de trabalho e lança mão de diversos recursos para combatê-los. Esses recursos refletem as concepções sobre os acidentes que, como veremos, permeiam os discursos analisados, especialmente no que se refere ao papel norteador da dicotomia atos inseguros-condições inseguras.

Tendo sido apresentadas as principais características da empresa-caso, as formas de enfrentamento dos acidentes empreendidas pela equipe de segurança e pela CIPA, isto é, o funcionamento institucional cuja existência antecede a entrada de cada trabalhador e a ele se impõe como realidade dada por certa, trataremos agora das práticas discursivas através das quais os trabalhadores - tendo por base os conteúdos do imaginário social e as modulações neles produzidas pelo contexto institucional - dão sentido aos acidentes de trabalho .

\subsection{O acidente de trabalho nas práticas discursivas}

Os acidentes de trabalho são temas recorrentes na fábrica. As notícias espalham-se velozmente pelos canais informais de comunicação e todos querem saber como foi, quem se feriu, qual a gravidade. O assunto é objeto de acaloradas discussões nos intervalos, nos horários de refeições e nas reuniões semanais de segurança. Todas as pessoas têm casos para contar e opiniões sobre acidentes que sofreram, presenciaram ou ouviram falar. $\mathrm{O}$ assunto é controvertido: de quem foi a culpa? O acidentado se distraiu ou foi um problema mecânico? A máquina era insegura ou tinha proteção? O trabalhador estava usando EPI? Se o operador sabia que a máquina estava dando problema, por quê não avisou à chefia? Por que a segurança não tomou providências antes? O trabalhador estava cansado ou com algum problema em casa? A máquina já havia falhado antes? Para a maioria das questões que surgem nesse constante debate, existem diferentes posições a partir das quais o acidente pode ser compreendido e que carregam diferentes concepções sobre o fenômeno em pauta. Mas não se trata de um debate entre pessoas com opiniões diferentes, cada qual com convicção daquilo que defende. Pelo contrário, o posicionamento depende da situação, do acontecimento "em si" e da ponderação dos argumentos favoráveis e desfavoráveis a cada uma das versões dos fatos. Posicionar-se nesse contexto francamente argumentativo é uma experiência vivida de forma dilemática: é sempre difícil dizer se foi uma coisa ou outra e é muito provável que se hesite ou se volte atrás nas primeiras opiniões, embora existam concepções hegemônicas. Como decorrência, os acidentes de trabalho não são compreendidos de forma única nem têm seus significados previamente estabelecidos: a 
partir dos repertórios argumentativos que discutiremos a seguir, diferentes significados são construídos no interior das práticas discursivas.

Sendo assim, a interpretação proposta pauta-se pela busca das diferentes posições e das formas como os significados dos acidentes são construídos nos discursos. O interesse em analisar a controvérsia que essas posições estabelecem convida ao estudo da polissemia que instauram, da conformação dos argumentos que as sustentam e das precondições contextuais que lhes conferem características dilemáticas.

Com relação a esse último aspecto, veremos que as posições contrárias analisadas - para que o diálogo argumentativo possa acontecer - partem de lugares-comuns, isto é, da fonte semântica que paradoxalmente fornece as sementes para os argumentos utilizados por repertórios interpretativos opostos.

A exposição das práticas discursivas estudadas está dividida da seguinte maneira. Primeiro, são apresentados os repertórios interpretativos sobre os acidentes e suas causas. Segundo, considerando-se a importância destes assuntos para a compreensão da presença marcante das idéias psicológicas, são discutidos o processo de naturalização dos riscos e as práticas institucionalizadas de difusão dessas mesmas idéias. Em terceiro lugar, são apresentadas as rupturas com as explicações dominantes e as tentativas de resistência a elas. Finalmente, são feitas considerações a respeito da relação entre as permanências culturais moduladas pelo contexto institucional e as práticas discursivas cotidianas.

\subsubsection{O acidente de trabalho e suas causas}

A controvérsia de que se falou acima será tratada a partir de uma aproximação gradual aos repertórios que alimentam o debate sobre as causas dos acidentes, começando-se pelas variações em torno de alguns aspectos da natureza desse fenômeno presentes nos discursos: sua definição e as questões ligadas ao determinismo causal e à intencionalidade.

A polissemia da expressão "acidente de trabalho" começa pela sua própria definição, que apresentou três variações em função da ênfase dada a diferentes aspectos do fenômeno.

A primeira, define todo e qualquer ferimento como acidente de trabalho, incluindo, assim, desde pequenos cortes - que não alterariam o desempenho no trabalho - até grandes lesões, que levariam a afastamentos para tratamento médico.

A segunda variação está baseada na compreensão de que pequenos ferimentos são normais e fazem parte da profissão. Assim, só seriam considerados acidentes de trabalho os acidentes graves, que seriam passíveis de registro ou que levariam ao afastamento da atividade 
normal de trabalho. Note-se que essa variação corresponde à definição legal de acidente de trabalho, que se refere a alterações na capacidade para o trabalho:

Acidente do trabalho é toda lesão corporal ou perturbação funcional que, no exercício ou por motivo do trabalho, resultar de causa externa, súbita, imprevista ou fortuita, determinando a morte do empregado ou a sua incapacidade para o trabalho, total ou parcial, permanente ou temporária [Ferreira, 1986, itálicos nossos].

Um entrevistado, ao comentar sobre os acidentes no torno automático que operava, exemplifica como as pequenas lesões são consideradas parte de seu ofício e, portanto, não definidas como acidentes de trabalho:

[acidente de trabalho] ...pode acontecer, né, a peça soltar, quebrar um pino. Isso é normal. Até agora, graças a Deus... se aconteceu, aconteceu umas duas, três vezes só, mas num chegou a ter vítima, certo? Graças a Deus, num... num teve ainda, né... a não ser aqueles problemas, né, do cara machucar um... fazer um cortinho aqui, um cortinho ali... esses negócios de segurança, né. Isso ai é normal [...] Agora, pelo menos o meu setor lá, que eu trabalho lá, graças a Deus num... de vez em quando acontece, mas é coisa banal, sabe, é coisa de rotina: um cortinho aqui, o cara machuca um olho, machuca um braço, sei lá.... [P.: Certo.] ...alguma coisinha, mas não é coisa grave, certo? [Laércio, operador de máquina, entrevista 11].

Essas variações aparecem, por exemplo, no diálogo com um outro entrevistado, que situa

o uso de cada uma delas em momentos diferentes da história da empresa:

[P.: É, então, só uma coisa que eu queria saber é isso: o que é acidente?] Acho que acidente não é só cortar um braço, não é só perder uma perna que é acidente. [P.: Certo.] Até uma caneta que você derrubar no chão é acidente, porque ela foi feita pra não cair, né? [...] Caiu é um acidente, não é só perdendo um braço, perdendo uma mão. [P.: Sim.] Por exemplo, você perdeu uma unha é acidente, você perdeu... qualquer coisa que você perdeu é acidente. [P.: Tá.] Uma batida de carro é acidente. Tudo que venha acontecer que não pode acontecer e aconteceu é acidente. [P.: Certo. Mas no caso, você machucou a ponta do dedo...] É acidente! [P.: Mas você me falou que não sofreu acidente!?] Mas isso aí, nessa época, isso aí, não registrou, agora sim, agora é registrado como acidente, mas não era acidente antigamente. [P.: Ah, tá.] Você tá entendendo? [P.: Você tá dizendo que não é acidente porque não foi registrado.] Não foi registrado e não registrava mesmo, hoje não, hoje é diferente, hoje se você tirou sangue daqui [aponta para um dedo] é obrigado a registrar, já é como acidente. Mas eu nunca sofri acidente por causa disso, nunca sofri acidente por causa de nada. [P.: Tá certo, quer dizer então, acidente é quando é registrado?] Quando é registrado, quando não é registrado não é acidente. Você pode perder um dedo na forjaria, se você agüentar a parada mesmo e não for na enfermaria, não é acidente, não considera nada. [P.: Tá.] Então, por isso que hoje a firma, [...] eles leva lá e registra e é obrigado, porque se você machuca e não vai registrar, amanhã vai ter que acionar o negócio ali e vai falar: "Por que que você não foi lá?". O cara perde até o direito e a firma também se prejudica como isso, não é verdade? [...] O acidente leve não afasta, eles deixam ai dentro mesmo, mas eles fazem questão que venha aqui no laboratório e registra, porque acho que é muito importante registrar qualquer tipo de acidente que venha sair sangue, vem registrar. [P.: Qualquer lesão, né?] Qualquer lesão que o cara sofre, porque é importante pro cara e pra empresa também [Paulo, operador de máquina, entrevista 15].

Nesse depoimento, o entrevistado faz uso simultâneo das duas definições de acidente de trabalho expostas acima e revela os contextos nos quais elas são utilizadas. A primeira definição, 
que orienta as ações presentes do trabalhador é utilizada no contexto de uma nova política de segurança da Metalco, que impõe o registro de qualquer lesão. A segunda definição aparece como sendo pertencente a uma outra época, embora ainda seja utilizada e continue valendo para os eventos ocorridos no passado ou não registrados.

Além dessas duas variações, ainda há uma terceira, que diz respeito à relação do acidente com a atividade de trabalho. Em uma das conversas travadas em campo, um operador de máquinas falou sobre um acidente fatal, ocorrido há muitos anos atrás, no qual um operário da manutenção caiu de uma ponte rolante. O operador teve dúvidas em afirmar se o acontecido era um acidente de trabalho ou não, em função de uma outra informação a respeito do caso: o laudo médico afirmou que o acidentado sofrera um ataque cardíaco no momento em que transitava sobre a ponte rolante; sendo assim, como a queda não foi gerada por um fator ligado à atividade do trabalho, o narrador do acidente não foi capaz de decidir se a morte fora realmente um acidente de trabalho ou não.

Cada uma dessas variações servem a determinados propósitos quando enunciadas. A primeira definição aponta para o fato de que algo indesejado aconteceu, não importando a gravidade de suas conseqüências. A segunda, está interessada justamente na dimensão dessa gravidade e suas repercussões, que são avaliadas em função das alterações na capacidade de trabalho do acidentado, pois são elas que definem se a vida seguirá seu rumo convencional ou não. Por sua vez, a terceira variação, ao buscar a existência de uma relação intrínseca entre o evento nefasto e a atividade de trabalho, cumpre a função de determinar se elementos do ambiente fabril contribuíram ou não para sua ocorrência. $\mathrm{O}$ uso de cada uma dessas interpretações varia em função dos contextos em que são enunciadas, dependendo das circunstâncias em que ocorrem os acidentes e das políticas de saúde em voga.

Dois outros aspectos, o determinismo causal dos acidentes e a intencionalidade das ações que conduzem a eles, também apresentaram variações. Saber se os acidentes são resultado de uma conjunção de causas ou obras de mero acaso e saber se as ações que os produzem deterministicamente ou não - são involuntárias ou deliberadas são problemas que aparecem na discussão sobre a natureza dos acidentes de trabalho. Nos dois casos revelaram-se diferentes posições em relação à natureza dos acidentes.

No fragmento a seguir, um operador de martelo hidráulico fala da imprevisibilidade do acidente de trabalho ao mesmo tempo que descarta outras hipóteses explicativas:

Acidente, isso ai é imprevisivel. Você numa máquina, é muito tempo, e num piscar de olho você se arrisca, se acidenta, mas muitas vezes a pessoa pensa que é isso ou é aquilo: "é falta de atenção". Não, é porque aquilo ali, você está acostumado a fazer aquilo, aquele tipo 
de trabalho, muitas vezes: "mas fulano trabalha tanto tempo e, mas não acidenta...", mas não é isso, o acidente é imprevisível! [Roberto, operador de máquina, entrevista 17].

A mesma idéia de incerteza em relação ao acontecimento dos acidentes aparece no trecho abaixo, acrescida da constatação de que, mesmo tomando cuidado e trabalhando segundo as normas de segurança, os acidentes podem acontecer:

[P.: Por que que o acidente acontece?] Olha, eu... tem aquele dizer, né, "o acidente não avisa”. É ou não é? Ele não avisa e nem fala a hora que vai acontecer, certo? Às vezes cê pode tá trabalhando normal numa máquina, certo, e... que nem já aconteceu comigo mesmo, quando ela termina de fazer as peça, por exemplo, fica aquelas barra lá, fica tudo cheio de cavaco $^{37}$, né, grudado lá. Então, cê pega e puxa... leva lá e puxa: às vez, de você puxar, aquele cavaco pode avoá... [P.: Tá.] ...em você, tá entendendo? [...] Sobre acidente, num avisa, mas pode acontecer. Eu acho que mesmo que a pessoa trabalha prestando atenção, eu num sei não... eu trabalho normal, certo? A gente não pode também facilitar, tá entendendo? [Laércio, operador de máquina, entrevista 11].

Outro entrevistado aponta para a possibilidade de identificação das causas dos acidentes e de controle sobre elas através das medidas preventivas que considera cabíveis, embora não totalmente efetivas:

Acidente é uma coisa que acontece, né, sempre que acontece tem algum motivo, eu acho. E acho que a maioria das vezes é que o cara tá trabalhando pensando em outra coisa, tá preocupado com alguma outra coisa. Se o cara tá trabalhando de cabeça fria, concentrado no serviço, dificilmente vai acontecer, né? [Sérgio, ferramenteiro, entrevista 18].

As diferenças entre essas duas posições diante do determinismo causal dos acidentes de trabalho, que caracterizam o fenômeno ora como evento incerto, ora como passível de previsão e controle, dizem respeito aos limites - dos procedimentos preventivos e do poder que se pode ter sobre as causas dos acidentes - vivenciados pelos trabalhadores em seu dia-a-dia na fábrica. Se, por um lado, são persuadidos a confiar nas proteções das máquinas ou no imperativo de "tomar cuidado", por outro, constatam - na reconstrução que fazem dos acidentes ocorridos - que eles ainda assim acontecem. Pode-se supor que cada versão sobre o determinismo causal é utilizada com a intenção de salientar uma ou outra dessas dimensões da experiência com os acidentes, a depender do contexto interpretativo em que o fenômeno é compreendido.

Algo semelhante acontece com o debate na definição do caráter intencional ou involuntário dos acidentes de trabalho. Vejamos um exemplo no qual duas versões são confrontadas por um operador de máquinas:

[P.: Mas, o que você acha que faz com que o acidente aconteça? O que causa o acidente? É a sua opinião mesmo que eu quero saber.] $O$ que causa o acidente... [P.: É, por que o acidente acontece?] Às vezes... quando eu fui trabalhar na CIPA, um tempo na CIPA, o cara falou assim: "o acidente, não é que ele acontece...", assim, né? Diz que é provocado, né? Mas eu

\footnotetext{
${ }^{37}$ Cavacos são fragmentos cortantes de metal, que se formam durante a usinagem das peças.
} 
não creio nessa maneira não, que o acidente seja provocado, eu não acredito nisso aí não. Acontece, né... às vezes a pessoa costuma fazer uma coisa todo dia, imaginando ali, já que dá certo, uma hora acontece do cara acidentar. Eu não creio que há possibilidade do cara bolar um acidente, provocar um acidente, eu não creio nisso não: senão, o cara não acidentava, né, não acidentava, né? [P.: Por quê?] Não tem vantagem em se acidentar sabendo que vai se acidentar. Tem vantagem? Acho que não tem, né? [P.: Claro!] Então, se fosse provocado a pessoa podia bolar aquilo lá e dava certo, mas não é. Quando o cara pensa que não, já foi, já aconteceu o acidente [P.: Tá.] Deve ser a falha, né, que dá lá um branco no cara, deve ser assim... Eu não tô pra acidente não... [Tobias, operador de máquina, entrevista 19].

O próprio descuido - que, como veremos adiante, é uma das explicações mais recorrentes nos discursos - aparece com defesa contra as proposições que sugerem a intencionalidade das ações dos trabalhadores que teriam conduzido aos acidentes:

[P.: E será que todos os acidentes que acontecem são por distração?] [pausa] Acho que não. [P.: Não, não é?] Não... problemas, também, né... [P.: Problemas?] Como eu falei para você, problemas... problemas de familia, em casa... [P.: Ah, isso causaria também acidente ?] Acho que sim. [P.: Mas além da distração e problema em casa... Além disso...] O que que tem? [P.: ...que mais causaria acidente ?] [pausa] Descuido, né? Descuido. [P.: Tá.] Eu acho! [P.: Não, eu quero saber o que você acha...] Eu sei, mas é isso mesmo... [P.....para entender melhor...] Eu acho isso mesmo, o cara não vai se acidentar porque quer! [P.: Não, claro!] Certo! [P.: Eu acho que nunca!] Você fala assim... ah... você tá... na máquina de prensa... uma prensa: "ah eu vou me cortar aqui o meu dedo pra ficar no seguro, pra ter estabilidade e tal, esse negócio todo... [P.: Acho que ninguém faz isso, isso não existe!] É isso que eu tô falando para você!! [P.: Sim.] Certo, a gente não se machuca porque quer! [P.: Tá.] Acontece problema de descuido ou alguma coisa, eu acho que é isso... [Douglas, operador de máquina, entrevista 4].

A discussão em torno da intencionalidade das ações está relacionada com a distinção entre culpa e dolo, o que reedita no espaço cotidiano um grande debate do universo jurídico. A culpa diz respeito a uma "conduta negligente ou imprudente, sem propósito de lesar, mas da qual proveio dano ou ofensa a outrem"; o dolo, por sua vez, refere-se à "vontade conscientemente dirigida ao fim de obter um resultado criminoso ou de assumir o risco de o produzir" (Ferreira, 1986). Nos depoimentos acima citados, os trabalhadores insistem no fato de que os acidentes não são conseqüência de atos deliberados e planejados, mesmo em situações em que eles teriam sido supostamente produzidos por distração ou negligência, pois as ações às quais esses comportamentos conduzem não seriam voluntárias - isto é, envolveriam culpa, mas não dolo ${ }^{38}$.

$\mathrm{Na}$ maioria das vezes em que os acidentes são atribuídos pelos entrevistados a causas pessoais ou psicológicas - embora existam nuances entre distração e negligência - elas não são caracterizadas como voluntárias. Assim, a intencionalidade aparece nos discursos dos

\footnotetext{
38 Há que se discutir se os atos inconscientes, no sentido psicanalítico usual do termo, caracterizam dolo ou não. Se levarmos em consideração que o inconsciente é conceituado como uma espécie de "agência" onipresente localizada nos porões da consciência individual a determinar os comportamentos das pessoas, a questão da da intencionalidade ou da "agência" foi apenas deslocada para outro locus ainda dentro do indivíduo (a relação entre "agência" e inconsciente é discutida de forma brilhante por Varela, 1995).
} 
trabalhadores apenas de forma negativa, isto é, como idéia a ser criticada e desmerecida de forma veemente. Essa contra-argumentação, é claro, não se manifesta desvinculada de contexto algum, pois é uma resposta a velhas concepções que rondam o imaginário social dos acidentes desde as primeiras leis que asseguravam direitos aos trabalhadores acidentados e que se presentificam na seguinte afirmação feita por um técnico de segurança, ao falar da suposta "falta de caráter" de alguns trabalhadores:

Porque, eu já tive casos de pessoas aqui que estavam pra ser demitidas e puseram o dedo na máquina, pra perder um pedaço [mostra com um gesto a falange distal do segundo dedo] $e$ pegar a estabilidade, só pra não ser demitido [técnico de segurança, conversa informal].

Embora esse fragmento seja o único registro da afirmação explícita da idéia de intencionalidade dos acidentes, sua simples existência e todo o esforço dos trabalhadores em refutá-la demonstram a presentificação no contexto discursivo estudado de conteúdos extemporâneos do imaginário social.

Até aqui foram tratados aspectos dos discursos sobre os acidentes de trabalho - a respeito de sua definição e natureza - que tangenciam o nosso principal tema: os modos de compreensão e explicação de sua ocorrência. Como veremos adiante, as definições do que são os acidentes de trabalho, a possibilidade de controlá-los e a defesa de seu caráter não voluntário permeiam a ação de explicá-los. Essa ação encerra os aspectos mais claramente dilemáticos.

O dilema fundamental, vivido pelos trabalhadores, é decidir se os acidentes foram causados pelo próprio acidentado ou pelas máquinas, equipamentos, ferramentas, proteções etc. Desse modo, as práticas discursivas investigadas reeditam a dicotomia postulada por Heinrich entre atos inseguros e condições inseguras, de forma explícita ou velada. Essa dicotomia está presente em todos os discursos colhidos. Ela aparece, por exemplo, no seguinte fragmento de entrevista, com os dois conceitos heinrichianos justapostos:

[P.: O que que causa acidente? O que que acontece?] Ah, por um ato inseguro ou uma condição insegura... [Sérgio, ferramenteiro, entrevista 18].

Ou neste trecho da entrevista com um montador, no qual - embora os fatores pessoais determinantes do acidentes apareçam nomeados como "problemas em casa" ou "falta de atenção" - a mesma dicotomia é expressa:

Bom, o que causa o acidente é a condição insegura que você trabalha. O setor que você trabalha às vezes tem uma máquina com condição insegura, que não tem condição de você trabalhar nela, mas você tá trabalhando. Então isso causa acidente. E, às vezes, problema em casa, a falta de atenção da pessoa que tá trabalhando numa máquina, pode ser que corte um dedo, um braço, ou faça apenas um corte, já é um acidente, né? Então, isso ai é que causa o acidente. $O$ acidente pode vir a qualquer momento, você desligou um pouquinho, um pouco de falta de atenção da pessoa causa acidente mesmo. Tudo que a gente tá fazendo tem que ter muita atenção e não desviar o pensamento nunca, estar sempre com o pensamento 
naquilo que a gente tá fazendo. É esquecer o problema de casa, o problema de família, os problemas da gente, o problema financeiro... Esquecer tudo, a gente tem que tá atento naquilo que a gente tá fazendo. Tem que tá atento, fazer o que tem que fazer e não ficar pensando nos problemas. E a condição insegura que eu falei para você da máquina, às vezes [Geraldo, montador, entrevista 7].

Algumas vezes as ações dos trabalhadores e as condições de trabalho são apresentadas como complementares na produção dos acidentes, como neste exemplo:

Uma coisa vai andar junto com a outra, né? [P.: É.] Uma coisa anda junto com outra. [P.: Tá... você falou de mudar...] Não adianta mudar por mudar e... eu chegar e vim trabalhar do mesmo jeito, né? E... cê... não adianta cê melhorar as condições de trabalho e eu continuar nervoso, eu... trazer meus problemas de dentro de casa ou continuar distraído. Eu acho que as duas coisas, uma vai compensar a outra, não vai? É! [P.: Não sei...] Eu brigo com você pra você me dá... me dá... me dá uma condição melhor pra mim trabalhar. Você faz isso. [P.: Certo.] Certo. Porque, ali você tem cem funcionários, cento e cinqüenta, certo? Você faz isso. Eu trabalho do jeito que é pra trabalhar, chega o outro e trabalha diferente de mim, tá, não vai adiantar nada! Vai acontecer acidente do mesmo jeito! [...] Acho que uma coisa carrega a outra daí. Eu acho que cê tem que dar boas condições de trabalho, e eu fazer com que essas condições eu mesmo coloque em prática aquilo que eu sei, trabalhando certo, correto. Não fazendo é... como a gente faz, distraído. Às vezes, cê tá batendo papo com um, com conversa com outro, é esse tipo de coisa que acontece muito, né? É... é... a gente fala, a pessoa tá nervosa... parece que é mentira, mas é verdade: esse tipo de coisa acontece muito, acontece muito. Tem pessoas, tem caras que não sabe separar as coisas, né, e tem gente que reclama só por reclamar... tem gente que fala as coisas só por... diz as coisa só por dizer, sei lá. É muito complicado, muito... o ser humano é um... é um... ele é muito... ele é cheio de problema... [Edvaldo, inspetor de qualidade, entrevista 5].

Entretanto, há quase sempre a preocupação em decidir entre um ou outro fator como causa última, sem a qual o acidente não teria ocorrido e, mesmo quando atos e condições inseguras são idealmente apresentados como complementares, no momento de definir as causas de um acidente específico, isso é deixado de lado em função da busca pela causa sem a qual o acidente não teria ocorrido. Assim, mesmo que se reconheça a presença de outros fatores, é o evento decisivo que é definido como causa. Essa preocupação com a causa decisiva assemelhase à metáfora da cadeia de dominós de Heinrich, na qual a retirada de uma das peças seria capaz de interromper a seqüência desencadeada de eventos que conduzem aos resultados indesejados. Assim, decidir entre causas humanas ou mecânicas leva à definição, tanto de responsabilidades, quanto do objeto das ações preventivas.

A escolha entre uma ou outra causa é feita por meio de um modelo bastante estável, cuja função é definir a origem da ação decisiva que conduziu ao acidente. O operário que tem sua mão levada em direção à parte móvel de uma prensa - que, embora desprotegida, não apresenta defeito algum - está, segundo esse modelo, cometendo um ato inseguro, pois foi essa ação que permitiu a ocorrência do acidente, isto é, o contato do corpo com a máquina. Nesse caso, admitese a existência de um risco, mas ele não é considerado condição suficiente para o acidente, qualidade atribuída à ação humana. Por outro lado, quando o trabalhador desempenha suas 
atribuições do modo rotineiro e acontece alguma falha ou evento incomum na máquina - como o rompimento de uma correia ou a quebra de uma broca que é projetada contra o corpo do operador - nesse caso o acidente é atribuído às condições inseguras, pois a ação da máquina ou de seus componentes foi, segundo o modelo, condição necessária e suficiente para produzir o acidente, pois - não tivesse a correia rompido ou a broca quebrado - nada teria acontecido e a realização da tarefa teria prosseguido em seu curso normal. Com base nessas duas situações ideais, o modelo esboçado aprimora a definição dos conceitos heinrichianos: o ato inseguro é causa de acidentes quando se configura como ação não prescrita ou não esperada do trabalhador e a condição insegura, quando ação imprevista dos elementos que compõem o ambiente físico de trabalho ${ }^{39}$.

Mesmo sendo formas intrincadas de compreensão, podemos dizer que durante a ação de atribuir significado aos acidentes, vislumbram-se duas posições contrárias, baseadas em diferentes repertórios interpretativos. Se a teoria heinrichiana aparece na acidentologia como uma das possíveis teorias explicativas, aqui ela se impõe como princípio organizador das diversas explicações, dela derivadas ou não ${ }^{40}$. Assim, a dicotomia ato inseguro-condição é a base sobre a qual se dá o pensamento a respeito dos acidentes de trabalho e a sua constituição por temas contrários alimenta os debates que se desenrolam no interior das práticas discursivas, na forma de "lugares-comuns" que fornecem elementos para justificar pontos de vista opostos.

Naquilo que poderíamos chamar de repertório interpretativo dos atos inseguros - ou dos fatores pessoais - os acidentes de trabalho são explicados por distração ou negligência. A distração aparece como fruto de problemas psicológicos, problemas em casa, preocupações que desviam a atenção dos trabalhadores de suas tarefas. Aparece também através das expressões: "brincar", "vacilo", "facilitar", "descuido", "cabeça em outro lugar", "desligado", "nervosismo". A negligência evidenciaria-se na pressa por acabar o trabalho, na insistência em trabalhar com máquinas que apresentam defeitos, no "excesso de confiança", na "preguiça". Como já se comentou acima, a propósito da intencionalidade das ações, distração e negligência não são atos voluntários - embora a ausência dessa característica não retire a culpa que pesa sobre quem os cometeu, pois apenas elimina o caráter doloso ou de má-fé das ações.

\footnotetext{
${ }^{39}$ É interessante notar que, embora haja uma correspondência com a distinção feita pela teoria da atribuição entre causas internas (presentes no "ator") e causas externas (ligadas à situação da ação), não se pode considerar que a dicotomia que estrutura os discursos estudados seja independente do contexto em que se manifesta. Nesse sentido, Edwards \& Potter (1992), afirmam: "O ponto essencial é que as causas internas e externas não figuram como características singulares dos eventos, prontas a serem apreedidas perceptualmente ou inferidas automaticamente. Elas são construções proposicionais, cuja natureza e operação são discursivas e seu sentido depende das seqüências de atividades (culpar, perdoar, e assim por diante) das quais fazem parte. Não podemos sensivelmente listar, de modo descontextualizado, o conjunto de causas que são internas ou externas" [p. 98].
} 
Nos fragmentos de diálogos a seguir, dois dos entrevistados definem o conceito de ato inseguro, revelando várias possibilidades de sua manifestação:

[P.: O que que é um "ato inseguro"?] $O$ ato que o cara... é quando o cara faz alguma coisa que... e não é a maneira certa de fazer [...] o ato é, que nem aí, pode entrar esta parte que eu te falei do cara tá preocupado com outra coisa, às vezes é um serviço urgente, o cara então esquece um pouco da segurança, ai é culpa do operador. [P.: Em geral, qual desses dois é mais importante, o que causa mais acidente?] Acho que é o ato inseguro. [P.: O ato inseguro.] Eu, às vezes, eu tô trabalhando meio nervoso, você vê que você faz um monte de coisinhas erradas, leva uma cacetada no dedo. Agora, quando você tá trabalhando sossegado, tranqüilo, fazendo o seu serviço normal, dificilmente acontece alguma coisa, acho que é isso aí. [P.: Isso pra qualquer acidente?] Eu, até hoje, só tive acidente leve. [P.: Certo, graças a Deus.] No meu caso, eu percebi que é isso, às vezes meio avoado tal, aí acontece esses acidentezinhos. Agora, quando é acidente grave, ai é mais problema que dá em máquina... muitas vezes é ato inseguro também, o cara põe a mão onde não pode [Heleno, operador de máquina, entrevista 8].

[P.: E o que é ato inseguro?] Ato inseguro é, eu acho que é, uma pessoa que vê o perigo e que não dá certa atenção pra aquilo, sabe? Tenta fazer vista grossa, fala: "Ah, isso nunca vai acontecer comigo". Isto é um ato inseguro. [P.: Tá.] Pode acontecer com qualquer um, eu posso voltar e posso me estrepar... [P.: Ato inseguro, então, é quando você percebe o risco, então faz alguma coisa mesmo sabendo que está errado?] Sabendo que.. .que... a mesma coisa, o ato inseguro é você pega a carcaça, você é que vira ela no gancho, lá no alto você que vira ela. Você nunca pode virar ela pro seu lado porque é um ganchinho assim, se você vira ela, vai tombar pra cima de você, mas tem gente que faz isso... [P.: Ichi... e faz por quê?] Porque sei lá... Tem pensamento de louco! [P.: Tá.] Porque se aquilo cai não tem o que segure. Isso é um ato inseguro. [P.: Tá.] A pessoa sabe que aquilo pode cair por cima dele e faz. [P.: Tá.] Ato inseguro é puxar uma carcaça, puxar ela pra cima de você ou enfiar na corrente alguma coisa. [Marcelo, operador de máquina, entrevista 12].

Quanto ao repertório interpretativo das condições inseguras, os acidentes de trabalho são explicados por defeito ou funcionamento irregular das máquinas, equipamentos, ferramentas e pela ação inesperada de outros elementos do ambiente de trabalho. Esse repertório fica claro nas falas destes dois trabalhadores:

É... agora, não digo que é só pobrema do... da... têm pobrema na máquina, as vez o cara não vê e as vez a máquina tá oferecendo risco, e, quer dizer, eles não vê... [P.: Tá.] ...não enxerga aquilo, não dá... às vezes não consegue ver, por ser novo ou não tá bem orientado, ou por ele já conhecer a máquina, mas tem coisa que tá... ele não vai ficar olhando por baixo da máquina como é que tá, como é que não tá! Às vezes o pobrema tá embaixo e ele tá correndo um risco de... ele estourar, quebrar, e o cara se acidenta... [P.: Certo.] Então, aí acontece uma coisa dessa que o cara não tem como evitar, ai já é pobrema da máquina não tem como ele evitar. Ou solta o bloco do dispositivo, aí já não é pobrema dele [Bernardo, operador de máquina, entrevista 2].

[P.: E lá na montagem, que tipo de acidente costuma acontecer?] $O$ acidente que costuma acontecer lá? [P.: Isso.] Não é acidente muito forte, não, mas teve muita condição insegura lá também. [P.: Tá... "tem" ou "teve"?] Tem ainda, eles tão, hoje mesmo já foi feito uma reuniãozinha sobre isso aí. Você já viu aquelas talhas de levantar peça? Então, aquelas talhas tavam quebrando [P.: Quebrando a corrente?] Quebrando a corrente. [P.: Tá, eu vi.]

\footnotetext{
40 Adiante será discutida a introdução na Metalco da abordagem sistêmica dos acidentes, por meio da recente proposta de utilização do método de árvore de causas.
} 
Então, aquilo aconteceu lá do lado de onde eu trabalho. Aconteceu duas vezes, desde a época que eu tô aqui. [P.: Caiu alguma coisa?] Estourou a corrente e a peça caiu, um bloco em torno de oitocentos quilos caiu no chão, na frente de um cara, se caísse em cima dele tinha matado ele ou tinha arrancado as perna dele. Quer dizer, essa aí é uma condição insegura muito grave mesmo [...] Brincadeira, né? Os blocos mais leve lá, é em torno de setecentos, oitocentos quilos. Eu acho que tinha que ter uma manutenção preventiva naquelas talha e nas corrente para não acontecer mais isso, né? Deus me livre você sai de casa para trabalhar, você volta morto ou perdendo um braço [Geraldo, montador, entrevista 7].

Embora existam duas possibilidades de explicação, são os atos inseguros que predominam nos discursos. As transcrições abaixo exemplificam essa predominância:

[P.: Mas, assim, de um modo geral, porque você está contando alguns acidentes específicos, mas de um modo geral, por que um acidente acontece?] (pequeno silêncio) Olha, rapaz, o acidente, pra mim, é o que eu falei pra você: falha humana mesmo. Porque toda relação, relatório que faz do acidente, em qualquer firma, você vai, é constatado falha humana. [P.: E você acha que é isso mesmo?] É isso mesmo, não tem outra... [P.: Não tem outra causa?] ...não tem outra causa não. [...] Todos os acidentes... você pode por na cabeça que a máquina não falha. [P.: Mas, às vezes, não falha?] Não. [P.: Ás vezes não quebra alguma coisa?] Não, ela pode quebrar, mas, você, veja bem, a maioria, 99\% é falha humana. O acidente é falha humana [Paulo, operador de máquina, entrevista 15].

Agora, a maioria dos acidentes, não digo todos, a maioria dos acidentes é vacilo do ser humano, a maioria deles é vacilo do ser humano, uma vacilada... as vezes o cara exerce a função cinco, seis anos naquilo ali nunca acontece nada, um dia vacila e machuca. [Que que é "vacila"?] Vacila, é assim como eu te disse, o cara tirar atenção do serviço, tá com poblema fora e... mistura poblema, serviço... atenção no serviço com o poblema dele fora, então ele não vai mais ter a mesma mentalidade a mesma visão, cê entendeu, o pensamento naquilo. Quando você tá fazendo o negócio consciente cê vai procurar fazer daqui pra melhor, sempre melhor, cê desviou o pensamento, cê não vai fazer, já não tá com o pensamento, como posso dizer, pensamento muito no que você tá fazendo ali, atento no que você tá fazendo ali, é a mesma coisa: cê tá ali no negócio que exige visão sua, a maior atenção, ai você tá ali ó, você tira a atenção do que tá fazendo, olha, tira a atenção da gente, já não tá vendo o que tá fazendo. [P.: Claro.] Mais ou menos assim, então, a gente desvia, a gente é... o ser humano tem esses defeitos [Bernardo, operador de máquina, entrevista 2].

A mesma predominância aparece nos discursos de engenheiros de segurança, técnicos de segurança, supervisores e gerentes. Um engenheiro, por exemplo, disse:

Sabe, Fábio, eu acredito que os acidentes que a gente tem aqui não estão relacionados com as condições de risco, eu acho que tem outras coisas ai que provocam os acidentes. Eu não vou dizer que todo mundo, é uma minoria, mas que é negligente mesmo, que não tá nem aí pra segurança e ai se acidenta [...] e aí tem outra coisa também, você é psicólogo e sabe como é, o trabalho é monótono, ai o trabalhador pega a peça, põe na máquina, é, vai assim naquele ritmo até uma hora que se distrai e ai aperta o botão sem querer, a mão tá lá na zona de risco e ele se machuca [...] e tem também o fator psicológico mesmo, ele tá com algum problema em casa, alguma preocupação, ai vem pra firma assim e acaba se acidentando [engenheiro de segurança, conversa informal].

Quanto aos técnicos de segurança do trabalho, em uma dada ocasião, perguntou-se a dois deles quais eram, em sua opinião, as causas dos acidentes. Eles responderam que os acidentes 
eram causados por negligência, distração, problemas fora da empresa e por "fatores psicológicos". Perguntou-se se estavam falando assim pelo fato do pesquisador ser psicólogo. Disseram que não, que era assim mesmo que pensavam, pois os riscos da empresa estavam devidamente controlados.

Seria difícil pretender simplesmente afirmar que os técnicos e os engenheiros têm uma visão puramente culpabilizadora, pois a observação do trabalho de alguns deles demonstrou estarem efetivamente preocupados com os riscos e sua eliminação, apesar de suas afirmações sobre variáveis psicológicas como causa suficiente para a produção do acidente. Porém, independentemente desse fato, há razões para acreditar na hipótese de que as ações levadas a cabo pela equipe de segurança, como será visto adiante, têm levado os trabalhadores a assumirem para si mesmos a responsabilidade pela própria segurança.

Um dos primeiros supervisores com quem se conversou disse que os acidentes eram causados "Pela falta de orientação, pela falta de atenção do trabalhador [...] por aquela pessoa que, assim, como eu vou dizer, que não tem o senso de perigo". Para ilustrar sua afirmação, citou um exemplo: um operário percebeu que sua lima estava com o cabo solto e resolveu consertá-la; colocou a lima verticalmente sobre a mesa, encaixou o cabo e bateu nesse com a mão; com o movimento, a lima partiu-se e uma parte dela penetrou sua mão. Continuou, dizendo que os acidentes em seu setor costumavam ser pequenos cortes nas mãos gerados por rebarbas, cavacos e cantos vivos das peças produzidas ou então quando o trabalhador "deixa o dedo debaixo da peça".

Por sua vez, um gerente afirmou que os acidentes aconteciam nos lugares onde havia menos riscos em potencial, onde seriam menos esperados de acontecer e, por isso, a única explicação que lhe parecia cabível era a responsabilidade dos trabalhadores pelos próprios acidentes, por cometerem atos inseguros, por não tomarem cuidados ou até por problemas ou "fatores psicológicos". Prolongou sua lista, incluindo a negligência, a distração e a preocupação com problemas fora da empresa como fatores que levariam aos acidentes.

Essa predominância de explicações calcadas nos atos inseguros reflete, entre outras coisas, a eficiência da difusão das idéias culpabilizadoras apontada por Cohn \& cols. (1985) e Santos (1991). Entretanto, essa predominância não significa submissão total às idéias dominantes, pois elas próprias encerram contradições evidentes ou implícitas e são confrontadas pelos acontecimentos do cotidiano.

O processo de dar sentido aos acidentes e explicar suas causas baseia-se em lugarescomuns estabelecidos a partir da ampla aceitação da dicotomia atos inseguros-condições 
inseguras, em que se baseiam os repertórios contrários exemplificados acima. O conjunto dos depoimentos analisados retrata um intenso debate, no qual a argumentação a favor de cada uma das posições existentes inclui contra-argumentos dirigidos à posição contrária, de modo que ambos repertórios presentificam-se nos discursos, como afirmação ou como negação. Examinemos alguns exemplos.

Um operador de máquinas, há doze anos na Metalco, defende sua posição a favor dos atos inseguros da seguinte maneira:

A Metalco tem condições porque ela tem um almoxarifado, tem a porca lá, tem o parafuso, cabe a nós operador, preparador ir lá requisitar. Se ela não tivesse aquilo no almoxarifado, então, tudo bem, ela não tá dando condições, mas tem lá! Então a maioria dos acidente acontece por uma imprudência nossa [...] Proteção, as proteções, tem a manutenção que faz, é só fazer o documento e, às vezes, pode até demorar porque tem algumas coisas mais crítico na frente, mas eu acho que se todos nós trabalhar com cuidado, atenção e determinação, o acidente elimina bastante, que a maioria dos acidentes são descuido nosso mesmo [Heleno, operador de máquina, entrevista 8]

Nesse depoimento, o descuido como causa de acidentes é defendido em detrimento das condições inseguras, que não existiriam ou estariam controladas em função do fornecimento de peças para reposição e a facilidade de instalação de proteções em máquinas e equipamentos. A mesma estrutura argumentativa aparece no trecho de entrevista abaixo:

Não tem outra causa. Sabe por que não tem? Porque no caso da Metalco, aqui, a Metalco, ela oferece manutenção, ela não obriga a gente a trabalhar com máquina ruim, pra isso nós temos reunião cada quinze, cada oito dia sobre segurança; então, é avisado lá: "Máquina ruim pára, manda arrumar". Então, às vezes, o operador tá trabalhando, o prensista, o cara da recalcadora, o que vai acontecer? "Ah, pô, mas agora é dez e meia, daqui a meia hora é hora do almoço, eu trabalho até onze, depois nós manda arrumar". O que que vai acontecer neste intervalo de tempo? A máquina te pega. Não é verdade? Então, perde a meia hora, faz a mecânica, depois volta a trabalhar: vai embora inteiro pra casa. Por quê? Vai pegar de surpresa? Vai! Então, por que que a máquina tá ruim o cara trabalhou com ela ruim, não é falha da máquina: já volta de novo, é falha humana, sem dúvida. Um acidente na estrada que você bate na traseira do outro, não conseguiu frear o carro, você acha que é culpa do carro? [P.: Se o freio estiver ruim...] É falha mecânica? É falha humana! [P.: Por quê?] $E$ falha humana, porque você saiu de casa, o freio tava ruim: "eu vou assim mesmo porque é ali mesmo", então não sai, pô! [P.: Tá.] Se o freio tá ruim, então não sai! Sofreu acidente? falha humana, por que não mandou arrumar. $O$ acidente de qualquer forma que ele acontece é falha humana, não tem como fugir disso ai não [Paulo, operador de máquina, entrevista 15].

Contra-argumentos também são formulados para a defesa de posições favoráveis às explicações baseadas no repertório das condições inseguras. Vejamos o que diz este entrevistado:

...tecnologia, né, tá avançando, então, a Metalco tá procurando acompanhar, tá entendendo? Agora, se você trabalha numa máquina, óia só, numa máquina que não tem condições nenhuma de segurança... Que não tem nenhuma proteção... [P.: Certo.] Cê entendeu? Por exemplo [...] o cara trabalha aqui, a máquina tá lá, soltando cavaco pra tudo quanto é lado, assim ó, tá entendendo? Então, vai acontecer acidente... isso é uma coisa que pode evitar. É onde acontece que eu acho que o operador não é culpado. [P.: Isso é 
verdade.] Cê entendeu? O operador não tem culpa... o operador tem culpa, às vez... a maioria das vez ele pode ter culpa, às vez, mas por distração, se ele tá trabalhando numa máquina e tem bastante segurança... [Laércio, operador de máquina, entrevista 11].

Em sua opinião, a existência de condições inseguras - cavacos arremessados por um torno - torna injustificável a explicação de acidentes baseadas em fatores humanos. Outro entrevistado descarta a hipótese de ato inseguro com base na afirmação da experiência profissional do acidentado, sustentando por essa razão a explicação baseada nas condições inseguras, no caso, uma falha mecânica:

... eles embutem um tipo de um anel na caixa do diferencial, e ele exige uma pressão. [P.: Certo.] Eles falam, assim, eles falam que é erro, é, como que é? Foi falha mecânica da máquina, aquela, aquele ali foi no comando, né, cê apertou o comando, cê solta ela, ela baixa e sobe, né... [P.: Certo.] ...se cê aperta, ela baixa, se solta, ela sobe e ele, segundo ele lá, apertou, soltou, só que ela abaixou de novo, ele acha que foi uma falha mecânica ou elétrica [...] ele tava acostumado fazer aquilo todo dia, toda hora e ele não ia apertar o botão com o dedo debaixo! [Caetano, operador de máquina, entrevista 3].

Desse modo, a compreensão do sentido argumentativo do debate em torno dos acidentes de trabalho e de sua construção a partir de posições contrárias revelam as características dialógicas das práticas discursivas estudadas. Além disso, a polissemia dos discursos abre espaço para outras variações semânticas, como veremos a seguir.

Em algumas descrições de acidentes ocorridos, observa-se um outro tipo de fenômeno discursivo. Nesses casos, o acidente é explicado através do repertório dos atos inseguros, mas, paralelamente aos argumentos principais, aparecem referências a condições inseguras que não são compreendidas pelo enunciador como causas dos acidentes. Um exemplo disso é encontrado no relato de um trabalhador, que ao falar sobre as causas dos acidentes em geral, faz referência às queimaduras que sofreu devido ao contato com oxigênio líquido no momento em que trocava o gás de uma empilhadeira:

Eu acho que... é um pouco de descuido do operador, e no caso também não tinha nada pra mostrar, no caso lá da empilhadeira, se tivesse uma luva apropriada lá pra... [com uma placa dizendo] "isso aqui é pra trocar oxigênio da empilhadeira", então, na própria empilhadeira. Mas não tinha nada, né? Eu já tinha trocado outras vez e nunca tinha sofrido isso... [P.: Tá.] ...e esse dia aconteceu. Se tivesse lá uma luva apropriada pra fazer esse tipo de serviço, talvez isso não aconteceria. [P.: Mas por exemplo esse acidente que você se queimou, você achou que foi distração sua ou foi a falta dessa luva que causou o acidente?] Foi distração minha. [Distração sua?] Distração minha [Ubiratan, instalador de manutenção, entrevista 20].

O mesmo fenômeno pode ser observado neste exemplo, em que o entrevistado relata um acidente causado, em sua opinião, pela pressa do operador e - embora tenha optado por um fator pessoal como explicação - apresenta de forma paralela uma peculiaridade das condições de trabalho, apontada pelo acidentado, que não é considerada causa do acidente: 
...o cara... peça pequena assim, no forno, ele foi tirar da bandeja... quis por tudo dentro de uma bandeja assim pra tirar do forno... com a pressa, colocou tudo dentro de uma bandeja... dai ficou pesado pra tirar fora, naquilo que ele puxou, a bandeja virou e veio por cima do braço dele e prensou o braço... [P.: Ah...] ...queimando, quente, aquilo quente nos dedo, assim! Ai ele gritando e os barulho das máquina, ninguém ouvia, né? [P.: Ninguém ouvia!] Ninguém ouvia! Aí, um colega meu correu lá... isso aqui queimou tudo, esses dois dedo dele ficou feio. Ele tem cinqüenta porcento do movimento desses dois dedo. [...] [P.: E por que aconteceu esse acidente?] Quer dizer, ele pra terminar o serviço logo ele colocou tudo de uma vez na bandeja. Onde cabia vinte peças, ele colocou trinta. [P.: Tá.] Ele puxou... ele.. .ele fala também que essa bandeja tem que ter um limite pra ela bater e parar, num tinha também, aí colocaram agora. [P.: Tá.] Agora, as vez alguém bate, mesmo que tiver cheia de excesso de peso, ela bate e pára. [P.: Certo.] Depois que aconteceu isso colocaram, sempre depois que acontece essas coisa eles colocam. Agora ela bate ali e pára, num tem perigo... [Arlindo, operador de máquina, entrevista 1].

Nesses dois exemplos, os acidentes são atribuídos a fatores pessoais - distração e pressa, respectivamente - mas na sua descrição aparecem fatores ambientais que também poderiam ser considerados causas, mas não o são. No primeiro caso, o fator ambiental apontado é a falta de luvas na empilhadeira para a realização da tarefa de troca de combustível. No segundo, a inexistência de um limite na bandeja. Em ambos, os fatores ambientais aparecem de forma insidiosa e os fatores pessoais permanecem como explicação principal. Como veremos adiante, esse fenômeno está fortemente relacionado com o que denominamos "naturalização dos riscos".

Em outras ocasiões, a utilização de um repertório revela-se como justificativa da posição defendida pelo outro. O depoimento transcrito abaixo exemplifica bem esse deslocamento semântico:

Na minha, no meu modo de pensar o acidente só pode acontecer por isso, não tem outra, outra maneira de ocorrer acidente, ou é por um poblema psicológico seu, o que você tá pensando, cê tá operando uma máquina sem, sem, sem realmente tá concentrado naquilo que você tá fazendo, pensando numa outra coisa, ou, então, é uma condição insegura que você, que, apesar de você, muitas vezes, cê tá consciente que tem uma condição insegura naquele determinado equipamento, e você insiste ou, as vezes, desconhece, né, [P.: Tá.] não procura ajuda de alguém pra solucionar [Caetano, operador de máquina, entrevista 3].

Nesse trecho de discurso, o trabalhador define as duas formas pelas quais os acidentes, em sua opinião, podem acontecer. Entretanto, de modo peculiar, ao falar das condições inseguras como determinantes dos acidentes, atribui aos próprios operários a responsabilidade pela existência desses riscos, o que desloca a causa das condições inseguras para a insistência ou desconhecimento dessas.

De modo semelhante, a ação do trabalhador pode ser encarada como produtora de condições inseguras. Neste exemplo, o entrevistado refere-se à limpeza e organização do posto de trabalho como obrigação do trabalhador, que quando não cumprida levaria a acidentes:

A limpeza, a organização também é condição insegura, [P.: Sim.] não é verdade? O cara tá trabalhando num lugar, não organiza nada, tropeça, bate a cabeça numa bica de uma 
máquina, alguma coisa, ou passa a mão em alguma coisa que corta a mão dele lá. A limpeza, a organização, tudo isso aí é condição insegura. Só que é uma condição insegura da própria pessoa que trabalha lá. [Geraldo, montador, entrevista 7].

Nesse aspecto, encontra-se outro dilema vivenciado pelos trabalhadores da Metalco: se, por um lado, falam da obrigação que têm de verificar as condições de trabalho e de não aceitar o trabalho quando essas são inseguras, por outro, falam do medo que muitos têm de recusar-se a trabalhar ou exigir melhorias. Para alguns esse medo tem fundamentos, para outros, é um mito. Mito ou não, influencia a ação dos trabalhadores, que se vêem impulsionados a defender seu direito à integridade física, ao mesmo tempo que temem represálias caso deixem de cumprir as ordens para trabalhar. Esse dilema é exemplificado por um entrevistado no seguinte depoimento:

Quer dizer, uma máquina não tá com condição de trabalhar, o funcionário que tá trabalhando com ela tem que falar "não tem condição de trabalhar nessa máquina", chegar no chefe dele e falar: "não tem condição de trabalhar nessa máquina, ou você arruma ou eu não trabalho", é mais ou menos por aí. Precisa ser assim porque agora não tem mais este problema, porque você fala assim: "pô, a máquina tá com problema" e ele vai e manda arrumar, porque se caso a bomba estourar, estoura pro lado do chefe. Quer dizer, se tem [acidente] é mais por causa da pessoa, ele tem medo de falar, mas é muito pouco isso aí. Às vezes ele tem complexo de falar com o chefe, tem aquele medo de "Ah, ele vai me mandar embora" [Geraldo, montador, entrevista 7].

A obrigação de verificar as condições de trabalho e corrigi-las aparece também nos seguintes fragmentos:

Põe uma coisa na cabeça: que toda máquina, que todo dispositivo é... oferece a... condições de... seguro... [P.: Oferece?] Oferece. Agora, é claro que a gente tem que melhorar ele, porque quem faz a, como é que se diz... o ambiente de trabalho é o próprio funcionário, não é isso? [P.: É claro...] É claro, e se você tá trabalhando numa área, cê tá vendo que tem problema, qual é a obrigação sua? Ou arrumar ou pegar alguém... é... né... pra arrumar e não fazer que viu, e fazer... se acostumar com aquilo, porque aquilo lá vai te trazer poblema amanhã ou depois... [P.: Entendi.] ...uma hora cê esquece, se descuida e pode se machucar com o próprio erro que você viu e não corrigiu, né? [Bernardo, operador de máquina, entrevista 2].

[P.: Você diz, então, que depende da pessoa verificar se a máquina está em ordem...] Isso! [P.: ...antes de trabalhar?] E! Ah, vamos supor, falei um pouco... depende um pouco da empresa, mas acho que depende quase tudo da pessoa, né? [P.: Depende quase tudo da pessoa?] Dá pessoa, né? [P.: Como assim?] É, se ela num... se... ela sabe que tem que chegar na máquina, ou onde ela vai trabalhar, tem que verificar primeiro como que tá os riscos de acidente, ou se tá tudo normal, se tá boa, não perguntar, não tentar se informar e já chegar trabaiando.. Se tiver alguma coisa solta, fora, dai pode acontecer um acidente [Irineu, operador de máquina, entrevista 9].

O medo refere-se a "ficar marcado" ou ser demitido, como nos exemplos abaixo:

Às vezes você tá vendo, tá enxergando que a máquina tá com problema, mas você não quer falar com o chefe, às vezes a pessoa tá com medo de perder o emprego, fica com medo de falar e aí perde um dedo, uma mão, por causa desse problema [Geraldo, montador, entrevista 7]. 
Eles tem medo do chefe, é... porque o pensamento do peão é esse aí: "eu começo a levantar problema, meu chefe me marca e ai pronto". Eu acho que esse tipo de coisa acabou faz tempo, não é, meu? Se é pra melhorar o ambiente de trabalho tem que falar, não é? Mas é dificil, o pessoal, não sei, a cabeça deles ainda não tá tão aberta pra isso, aí fica difícil [Edvaldo, inspetor de qualidade, entrevista 5].

No segundo exemplo, o entrevistado descarta as razões para sentir medo, situando-as no passado, mas aponta a dificuldade de banir esse receio e as conseqüências que sua existência tem para as ações dos trabalhadores.

A possibilidade de parar existe efetivamente na opinião de outro entrevistado, mas em geral em situações de risco muito grave:

[P.: Quer dizer, dá pra parar qualquer máquina, então, se ela tiver com, com...] Se tiver com risco que não dá pra trabalhar, não tem jeito, dá pra parar. [P.: Tá, Se for esse risco quatro, aí, mais... ] Isso, se chegar à morte [P.: Risco de morte.] Isso, opa aí vai, aí vai até do operador, né meu! [P.: Tá.] Se o cara fala: "Pô a qualquer momento eu posso morrer aqui, que é isso!?" [P.: Sabe que você tem direito de recusar...] Claro, ô, e eles mesmos falam pra gente que... Bom, eu, eu, a partir do momento ... eu preciso muito do emprego, isso e aquilo. A gente sabe como é que funciona, assim, se você vai se recusar a fazer um serviço e uma série de coisas, você já fica meio marcado, né? [P.: Certo.] Mas, eu, se eu vejo que não tem condições de trabalhar, eu não trabalho não [Irineu, operador de máquina, entrevista 9].

Se o risco de morte, como a conseqüência mais grave que o acidente pode oferecer, torna viável a interrupção da atividade de trabalho, que relação pode ser estabelecida entre a possibilidade de parar e a gravidade dos riscos? O que define o momento em que o trabalhador deixa o medo de lado e se recusar a trabalhar? Acreditamos que essa ação repousa sobre a definição de risco aceitável.

O dilema entre a idéia de um trabalhador que verifica os riscos e recusa-se a trabalhar quando não considera seguras as condições e a de um trabalhador que tem medo de agir assim ou que é negligente e não dá atenção às possíveis ameaças a sua saúde advindas do ambiente de trabalho, aponta para um conflito político cujos elementos são a preservação da saúde, por um lado e a produtividade e garantia dos meios de subsistência, por outro. Esse conflito tem seu paralelo nos discursos estudados e é anterior à decisão de atribuir os acidentes a atos inseguros ou a condições inseguras. Ele expressa a contradição de interesses entre os que detém os meios de produção e aqueles que somente possuem sua força de trabalho. Essa contradição, que marca o contexto social global - envolvendo o confronto entre diferentes grupos sociais - determina a existência de práticas de dominação e de resistência, as quais permeiam a produção dos significados dos acidentes de trabalho no contexto da interação.

Se a teoria heinrichiana oferece os lugares-comuns a partir dos quais ambos os repertórios - dos atos ou das condições inseguras - vão buscar as sementes de seus argumentos e contraargumentos, assim como nessa teoria, as explicações calcadas nos fatores pessoais são utilizadas 
para compreender a maioria dos acidentes. Isso não quer dizer que os riscos não são reconhecidos enquanto tais ou que não estão presentes nos discursos de modo afirmativo, mas que não são reconhecidos como a causa última dos acidentes, na mesma medida que são os atos inseguros. Podemos hipotetizar algumas razões para isso. Primeiro, porque a importação dessa teoria acidentológica trouxe consigo os preconceitos inerentes a ela e apontados por diversos atores (Arouca, 1975; Binder \& cols., 1994; Santos, 1991; Silva, 1995). Segundo, pela existência de um processo discursivo que denominamos de "naturalização dos riscos", que elimina do horizonte cognitivo a possibilidade de mudanças ambientais. Terceiro, pela existência de mecanismos institucionais que, imbuídos por essas concepções, acabam por reproduzi-las (Santos, 1991). A naturalização dos riscos e os mecanismos institucionais de perpetuação dessas concepções sobre os acidentes são discutidos nas seções a seguir.

\subsubsection{Naturalização dos riscos}

As formas predominantes de explicação dos acidentes na empresa-caso partem, grosso modo, do repertório dos atos inseguros. O poder de convencimento desse repertório interpretativo está baseado em mecanismos retóricos que refutam outras explicações possíveis, as quais são deixadas em segundo plano nos debates sobre os acidentes - embora não abandonem totalmente a arena discursiva, como visto acima. Os argumentos mais importantes, que garantem essa hegemonia, recebem respaldo de um processo que denominamos naturalização dos riscos.

A naturalização é um processo pelo qual objetos sociais historicamente localizados são transformados em objetos naturais e a-históricos, isto é, deixam de ser circunstanciais, datados ou convencionais para revestirem-se como necessários, dados por certos ou imutáveis. Parafraseando Montero (1995), as condições de trabalho "aparecem com a força de fatos naturais, habituais, como se fossem um conhecimento compartilhado por todos, não sujeito a discussão" (p. 88). Dessa forma, esse processo antecede o próprio uso dos repertórios interpretativos utilizados para a atribuição de significados aos eventos do mundo.

A naturalização dos riscos significa a inexistência de um horizonte próximo de possibilidades de mudanças das condições de trabalho e expressa-se na linguagem através da nomeação dos riscos como "inevitáveis" ou "inerentes ao trabalho". A conseqüência mais visível da naturalização é a limitação das possibilidades de prevenção, pois, não podendo o micro-ambiente da fábrica ser outro, não restaria outra alternativa, a não ser intervir sobre a única dimensão do trabalho aparentemente passível de modificação: os próprios trabalhadores, através de seleção ou treinamento. 
Identificaram-se três maneiras pelas quais a naturalização aparece nos discursos estudados. Primeiro, por meio da restrição da definição de "risco" apenas aos defeitos em máquinas e aos acontecimentos inesperados que elas originam. Desse modo, diversos elementos do ambiente de trabalho - como altas temperaturas, máquinas cujo funcionamento normal ocasiona acidentes etc. - são em geral descartados como riscos. Segundo, esses elementos do ambiente de trabalho também podem ser admitidos como riscos de fato, mas, nesse caso, são considerados inevitáveis ou inerentes à atividade de trabalho. Ainda, os riscos percebidos como inerentes podem ser considerados como estando "sob controle", isto é, prevenidos por meio da instalação de proteções ou do fornecimento de EPIs aos operários. Da mesma forma como a idéia de "risco aceitável", a definição de "risco sob controle" não advém de um conhecimento sem mediações da natureza dos riscos, mas depende da negociação baseada em pressupostos compartilhados.

As variações assumidas pela naturalização dos riscos refletem o discurso patronal e estatal, referido no capítulo anterior - reformulado e difundido durante o chamado "milagre econômico". Esse discurso qualifica os riscos dos ambientes de trabalho como decorrências inevitáveis do desenvolvimento tecnológico necessário para o progresso nacional e conclama para que os esforços preventivos voltem-se aos trabalhadores, pois eles não estariam preparados para conviver com as novas tecnologias e deveriam ser treinados com a finalidade de reverter esse quadro nefasto (Santos, 1991) ${ }^{41}$.

A naturalização pode ser melhor compreendida através da análise de sua manifestação nos discursos dos trabalhadores estudados. A começar pela definição de riscos apresentada por um dos entrevistados:

[P.: E o que é risco de acidente pra você? O que que é?] Um risco de acidente? [P.: O que é risco?] Risco de acidente? [P.: É.] É o seguinte: é uma coisa que você tá vendo e não conserta. Aquilo fica sendo um risco, né? [P.: Tá.] Quer dizer... ou senão aquela pessoa que trabalha dez anos na máquina e tem uma coisa, e tem uma coisa fora, que só ela sabe, ali, que os colegas da área ali sabe, né. [P.: Sei.] Aquele tipo de pobrema que é uma peça que tá mal, tá folgada, tá meio folgada, tá meio ruim e ele sabe o que tem que fazer com aquilo ali na hora de trabalhar. [P.: Tá.] Ai entra uma outra pessoa, meio inocente, ele esquece de avisar. Ali pode acontecer um acidente. [P.: Tá.] Quer dizer: aquilo é um risco, né? Bom é assim que eu penso [Irineu, operador de máquina, entrevista 9].

Nesse depoimento, o entrevistado define risco como algo errado a ser consertado. Acrescenta a essa definição a já referida obrigação de identificar e eliminar riscos. Em seguida,

\footnotetext{
${ }^{41}$ A idéia de risco controlado também já estava presente em Heinrich, que em 1941 - ao apresentar os resultados de suas pesquisas - declarava de forma otimista que os riscos ambientais já não eram mais tão importantes como causas de acidentes (Heinrich, 1959): "É sabido de um modo geral, já há alguns anos, que riscos mecânicos ou físicos vêm se tornando menos significativos como causas diretas de acidentes, mas não há evidência alguma de que a extensão dessa diminuição tenha sido medida por pesquisas de autoridade" (p. 19).
} 
apresenta outro exemplo no qual se opera uma mudança de significação: o risco continua sendo um defeito, porém não é mais um defeito a ser consertado, mas algo com que se deve conviver com cuidado, o que exigiria do trabalhador algum tipo de conhecimento prévio das peculiaridades das máquinas e equipamentos.

A imagem dos riscos inevitáveis aparece de diversas maneiras nos discursos dos entrevistados. No seguinte diálogo, o entrevistado fala da impossibilidade de eliminação de todos os riscos nas empresas em geral, dos riscos que não são percebidos e faz alusão àqueles existentes fora da fábrica, como os do trânsito:

[P.: O que que é mais sério, o que evita mais acidente, tomar cuidado ou eliminar risco?] Tomar cuidado. [P.: Tomar cuidado. Mas se você elimina os riscos aí não tem risco e não tem como o sujeito se acidentar... que que você acha?] Bom se você for eliminar todos os riscos que tem... Eu não sei se tem uma empresa que tem isso ai não. Porque tudo tem risco, você vê na rua, já pensou se todo mundo dirigisse certo, havia acidente? [P.: Concordo.] Você vai na sua faixa, vai na sua mão, você dá seta... por que que acontece? Porque, imprudência. Igual à máquina, certas coisas dá pra fazer pra eliminar risco, mas outras coisas você nem percebe [Heleno, operador de máquina, entrevista 8].

Outro trabalhador, ao comentar sobre uma acidente famoso ocorrido algumas semanas antes da gravação da entrevista, revela o mesmo tipo de naturalização dos riscos. Ao afirmar desconhecer os detalhes desse acidente, recorre a uma explicação genérica baseada na necessidade de existência de características das máquinas que, embora perigosas, são necessárias para o seu funcionamento ou não são passíveis de proteção:

[P.: Mas, por exemplo, no acidente com o "Rubão" que você contou aí, se não tivesse aquele buraco na máquina onde pudesse cair a ferramenta, não teria acontecido acidente... o que você acha disso?] É, mas, é que eu não sei muito bem como que é a máquina, lá. [P.: Tá.] Não sei se é um... eu não sei se é um canto assim no meio... eu sei que... o cara que trabalhava lá, trabalhava há muito tempo e nunca tinha acontecido nada [P.: Tá.] Vamos supor se não tivesse esse buraco, igual você falou aí, não cairia dentro, né, a chave. Mas, eu não sei como funciona a máquina, mas às vezes precisa ter aquele buraco pra poder algum tipo de movimento pra máquina, né? Ou mesmo da ferramenta que vem, pra poder correr dentro, às vezes a máquina precisa... [P.: precisa ter...] ...precisa ter, não tem como ficar sem, e não tem como por um tipo de... de proteção, é mais de você. [P.: Tá.] É mais da gente, né? Esse tipo de coisa [Irineu, operador de máquina, entrevista 9].

A inevitabilidade dos riscos também aparece nesse fragmento, em que o trabalhador discute acidentes ocorridos durante a manipulação de peças pesadas:

É... agora, no caso do forno, cê coloca uma peça do outro lote, ai tem que tê atenção porque num tem como cê colocar um dispositivo pra evitar aquilo, como é que cê vai colocar? [P.: Como assim? Explica melhor...] Porque, cê... naquilo que eu falo que é falta de atenção, cê pega uma peça pra colocar em cima da outra, cê deixa os dedo debaixo e prensa os dedo. Não tem como cê colocar... como se diz... um dispositivo ali pra evitar aquilo ali... [P.: Pra evitar.] Ai que eu acho que é atenção. [P.: Tá, entendo.] [Arlindo, operador de máquina, entrevista 1]. 
Há no entanto a percepção de que alguns riscos são elimináveis ou controláveis, como neste diálogo:

[P.: E se a gente fosse pensar em maneiras de prevenir acidente, né, evitar acidente o que que você acha que a gente tinha que fazer pra ter menos acidente, pra evitar acidente?] Pra evitar acidente? [P.: Isso.] Dentro de uma fábrica? [P.: Isso, que que tem que ser feito?] $A h$, eu... sabe, tem certas máquinas que não tem como você ter uma proteção. [P.: Sei.] Então, isso vai do que? De uma consciência, tá? Da sua responsabilidade de tá ali ó, da própria máquina, né, que você tá trabalhando ali vai procurar trabalhar com atenção. [P.: Tá.] Certo, já tem outras que dá pra colocar uma proteção pra você não se acidentar. [P.: Tá.] Certo, que nem é, tem várias máquinas ai dentro que, de repente, você é... pelo fato de ter acidentes, então eles trabalharam em cima pra colocar proteção e tal, então tem proteção pra você evitar o risco, né? Então eu acho que é isso dai [Orlando, operador de máquina, entrevista 14].

Os riscos controlados são, segundo os trabalhadores, aqueles que, embora considerados como tais, têm sua letalidade reduzida em função de medidas de proteção e, especialmente, do uso de equipamentos de proteção individual.

A naturalização aparece também nos discursos dos membros da equipe de segurança. Um engenheiro de segurança, por exemplo, deixa isso bem claro ao fazer a seguinte declaração:

Porque, assim, o risco existe, disso eu não tenho dúvida. Agora, tem risco que não tem jeito, sabe, que é inerente à atividade... [...] então a pessoa tem que ter consciência [...] Então, eu não colocaria lá dentro um cara sem experiência nenhuma pra trabalhar [engenheiro de segurança, conversa informal].

Note-se que, em todos os exemplos citados até aqui, a impossibilidade de controle ou eliminação dos riscos é acompanhada pela afirmação do ato de tomar cuidado como a única forma possível de prevenção de acidentes nessas circunstâncias. Nesse movimento, o objeto da prevenção vislumbrada é transformado em causa dos acidentes, ocorrendo uma inversão de sentido.

A existência do processo de naturalização dos riscos não significa que as condições de trabalho não sejam consideradas perigosas. Muito pelo contrário, a maioria dos trabalhadores fala da periculosidade de seu trabalho e da conseqüente necessidade de "tomar cuidado" - muitas vezes é estabelecida uma relação diretamente proporcional entre riscos e cuidados: quanto maior o risco, maior o cuidado a ser tomado. Entretanto, esses riscos continuam sendo compreendidos como inerentes ao trabalho que realizam. Um trabalhador, por exemplo, ao comparar dois postos de trabalho afirmou: “...a máquina é mais perigosa, tem que tomar cuidado...” (Douglas, operador de máquina, entrevista 4). Outro entrevistado, ao contar sobre a sua atividade de trabalho, estabelece a mesma relação entre riscos e cuidados a serem tomados:

[P.: Então me conta um pouco do que você faz aqui na Metalco? Você é operador de máquinas e... como é o teu trabalho? Conta um pouquinho pra mim?] Meu trabalho aqui eu considero um trabalho mais simples do que eu já passei. E operar a máquina o cara tem que 
ter mais atenção e trabalhar com máquina o risco de acidente é muito grande. [P.: Tá] Então, o cara tem que ter muita atenção, sempre entrando no trabalho de cabeça fresca. Isso ai ajuda muito, é... e saber realmente o que tá fazendo, não ficar rolando no pé da máquina, com o pensamento lá fora. Tem que tá ligado ali, no que tá fazendo. Não acho um trabalho muito dificil não [Joaquim, operador de máquina, entrevista 10].

A naturalização dos riscos é, em algumas circunstâncias especiais, percebida pelos trabalhadores, mas como fenômeno produzido pelos anos de experiência em uma determinada tarefa, pelo hábito ou pelo "excesso de confiança". Segundo alguns entrevistados, as pessoas experientes, por conhecerem bem os riscos e as formas de esquivar-se deles, subestimam os mesmos. O habituar-se a determinadas condições de trabalho faz com que não sejam percebidas como perigosas:

[P.: Mas, assim, de certo modo, se não tivesse o cavaco, se não tivesse a ferramenta inadequada, talvez mesmo com a pessoa se distraindo, o acidente não ia acontecer...] $O$ acidente, não é que ele não iria acontecer, iria diminuir bastante. [P.: Certo.] De cem iria diminuir pelo menos cinqüenta porcento. Mas o fator humano sempre gera, né, o acidente. Eu mesmo... às vezes tô fazendo um trabalho e quando eu me vejo eu estou numa situação de risco. Estou fazendo um trabalho arriscado. Mas por que? Porque você vai, você se habitua também ao trabalho, vai se habituando. Você pega uma negócio pra fazer e quando você vê, você não deveria fazer dessa forma, poderia ter acontecido tal coisa comigo [Flaviano, montador, entrevista 6].

Da mesma forma, entendem que o excesso de confiança faz com que os riscos não sejam percebidos como tais:

Um colega meu que trabalhava na fiação, ele precisou subir em cima de um par de ferramenta. Era mais ou menos uns três metros assim de altura, ele precisou subir, ele pegou, subiu. Subiu sem cinto, sem nada, sem proteção nenhuma. Subiu na escada, subiu, também não avisou ninguém que iria subir, subiu para pegar uma coisa. [P.: Tá.] E nisso, não sei se ele pisou em falso... fui ver só quando ele já tava no chão. Não sei se ele pisou em falso em alguma coisa que caiu, afundou... [...] ...foi culpa do cara, total, né? De subir, de... foi confiança também, né? [P.: Tá.] de... já subiu lá umas dez vezes, quinze vezes, não falou nada, "não vai acontecer nada comigo, não". Acho que quando acontece esse tipo de acidente, acho que vai muito da pessoa, muita confiança. É... confiar muito na máquina $[\mathrm{P} .:$ Tá.] No caso dele foi confiar muito porque ele já tinha subido umas dez vezes, não tinha acontecido nada, ele ia subir a décima primeira e não ia acontecer nada de novo, né? Ai pegou e subiu. É igual a gente quando tá trabalhando com essas máquinas, a gente... bom, eu praticamente tô para nove meses nessa máquina, né... bom eu, pra mim, às vezes chego nessa máquina: "não vai acontecer nada, não!", tô fazendo uma peça com a porta aberta, lá tá a primeira que cê faz de setup, às vezes voa cavaco: "não, não vai acontecer nada, nunca caiu no olho, nunca fez nada". Até que agora... e a gente tá se conscientizando, né meu, a gente... não dá, na verdade, pra fazer com a porta fechada, mas a gente tenta fechar mais, toma mais cuidado. É confiança né? Então... pode ser que uma hora caia um cavaco no olho, cê entendeu? Então, é nestes tipos... mas aí, agora, a gente, a gente que pega uma certa confiança que às vezes a gente chega lá, põe uma peça, vai fazer, deixa a porta aberta: "ah, não acontece nada não", "vamos fazer, faz lá, rapidinho, nunca aconteceu...". Ai vai, acontece numa hora, então é bom se prevenir, não adianta insistir nesse tipo de coisa [Irineu, operador de máquina, entrevista 9].

Um engenheiro de segurança durante uma conversa comentou essa habituação aos riscos.

Falou que "para quem não está acostumado com o chão de fábrica os riscos parecem grandes", 
mas que as pessoas com experiência "acostumam-se com os riscos". Em seguida articula essa constatação com a produção dos acidentes através da distração e com a necessidade das práticas institucionalizadas de educação dos trabalhadores ao afirmar que esse mesmo habituar-se aos riscos fazia com que os trabalhadores não dessem atenção a eles, o que exigiria um "trabalho de conscientização". "Conscientização" significava fazer com que os trabalhadores passassem a perceber os riscos aos quais não prestavam mais atenção devido à sua familiaridade com eles.

Essas concepções - que estabelecem relações entre acidentes e experiência ou hábito coexistem com outras, que relacionam os acidentes à inexperiência, falta de conhecimento ou de treinamento dos operários:

Se eu sou operador velho naquela máquina, eu conheço bastante, eles mandam eu ensinar um colega meu: quando é com meia hora que eu tô ensinando o rapaz eles já mandam eu sair, fazer outro serviço e deixar o rapaz lá. Ai o cara não tem muita experiência, vai apertar um botão que não tem nada a ver, ai pode acontecer um acidente também, igual eu já ouvi dizer que ocorreu... [Heleno, operador de máquina, entrevista 8].

Se ter experiência conduz à subestimação dos riscos, não dispor dela significa desconhecê-los completamente, o que, naturalizadas as condições de trabalho, levaria também ao acidente.

Essa idéia - embora aponte para a necessidade de qualificação dos trabalhadores - conduz do mesmo modo à intervenção sobre o comportamento dos trabalhadores como forma de prevenção dos acidentes. Essas intervenções existem de maneira institucionalizada na Metalco e são discutidas abaixo.

\subsubsection{As tentativas de perpetuação de uma certa versão da realidade}

As concepções sobre os acidentes baseadas em fatores pessoais, como apontado no capítulo anterior, estão presentes na literatura especializada, bem como nas propostas educativas adotadas por instituições governamentais, de modo que foram amplamente difundidas através de diversos segmentos sociais. A simples menção disso já seria o bastante para explicar a forte presença daquelas idéias na empresa-caso. No entanto - como nas empresa de grande porte em geral - existem no contexto institucional estudado mecanismos complementares de difusão das formas de compreender os acidentes, que dizem respeito às práticas institucionalizadas de educação dos trabalhadores.

Diversos são os procedimentos de difusão de concepções sobre os acidentes presentes na Metalco, como as campanhas, as apostilas didáticas, as palestras periódicas e as semanas de prevenção de acidentes, que serão discutidas a seguir. Em todos esses exemplos predominam concepções calcadas na dicotomia ato inseguro-condição insegura e, da mesma forma, grande 
ênfase é conferida aos fatores individuais e psicológicos. Por isso, não é por acaso que essas concepções e essa ênfase tenham aparecido nas falas dos trabalhadores, como visto acima.

Muitas campanhas foram levadas a cabo nos últimos anos. Além daquelas mais comuns incentivando o uso de EPI, solicitando maior atenção na realização de tarefas, desestimulando brincadeiras e conversas durante o trabalho, presenciou-se durante o trabalho de campo o desenrolar da campanha "Cuidados com as mãos". Sua implementação deveu-se à constatação por parte da equipe de segurança de que a grande maioria dos acidentes de trabalho ocorridos ano após ano na Metalco atingiam as extremidades dos membros superiores (as mãos e os dedos que, por sinal, são as partes do corpo mais utilizadas e expostas a riscos mecânicos na empresacaso). Além de ser incluído nas palestras, o tema inspirou diversos cartazes espalhados pela fábrica, com advertências como: "Tome cuidado com as suas mãos, elas formam um par perfeito!"’. O tom sarcástico dessa frase afina com as afirmações de alguns membros da equipe de segurança e de alguns trabalhadores sobre a necessidade de despertar o medo dos operários para que se tornem mais cuidadosos.

As cartilhas, utilizadas em cursos ou distribuídas periodicamente aos operários, seguem o mesmo padrão das campanhas. Um exemplo é a cartilha ilustrada intitulada: A Vida é Frágil, Evite Acidentes - Manual Geral de Segurança, que sintetiza algumas das idéias em circulação na empresa:

....a prevenção de acidentes não depende somente de boas condições materiais, mas, principalmente, do elemento humano, ou seja, você [...] Grande parcela de responsabilidade na prevenção de acidentes cabe ao empregado não ao dirigente pois, devido à natureza de seu trabalho, é quem corre maior risco de acidentes, por estar fazendo trabalhos que exigem movimentos físicos, estar em contato direto com máquinas, equipamentos etc. [...] Para o seu benefício não seja igual a um destes: distraído, imprudente, gozador, curioso, sabido, ingênuo, exibicionista, displicente, teimoso ${ }^{42}$ [itálicos nossos].

O referido manual traz também a reprodução de um desenho ilustrativo da Teoria dos Dominós (figura c), idêntico àquele encontrado no Industrial Accident Prevention de Heinrich, publicado pela primeira vez em 1941. Sua presença demonstra uma vez mais qual é a principal fonte que alimenta as idéias da equipe de segurança a respeito dos acidentes de trabalho.

\footnotetext{
${ }^{42}$ Cada um dos tipos é exemplificado com uma ilustração caricatural.
} 
Figura C: A "Teoria dos Dominós" presente em apostilas fornecidas aos trabalhadores da Metalco

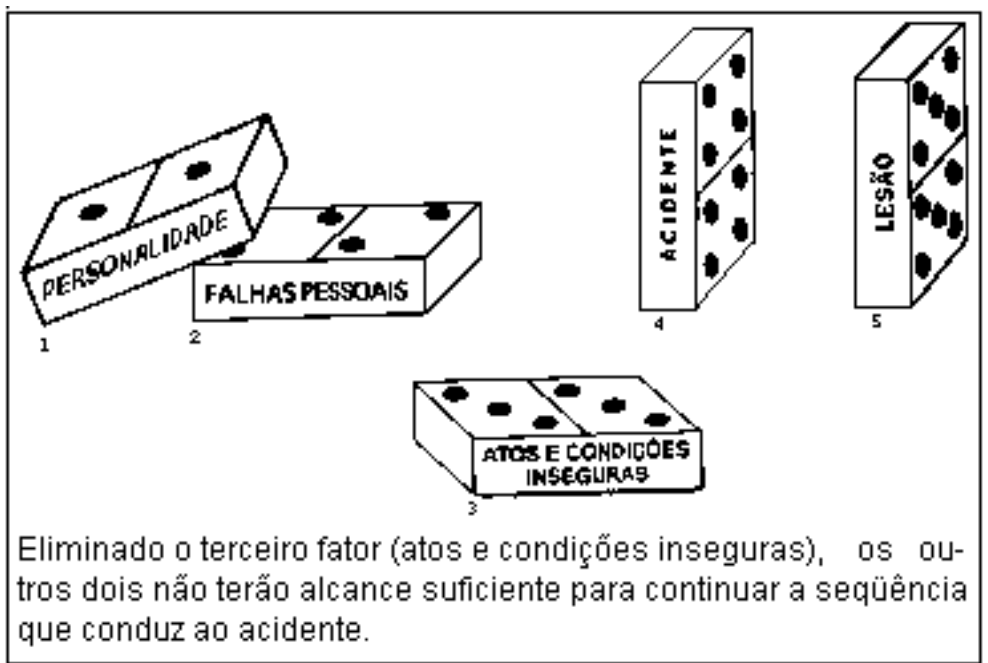

Fonte: A Vida é Frágil, Evite Acidentes - Manual Geral de Segurança, Metalco.

Além de serem alvo de campanhas e cartilhas, todos os trabalhadores da Metalco assistem a palestras semanais sobre saúde e segurança, durante as quais, além da exibição de filmes ou a apresentação de tópicos de segurança por cipeiros ou técnicos de segurança, são informados pelos supervisores dos setores a que pertencem sobre os últimos acontecimentos, sobre as metas da empresa e são convidados a falar sobre seu trabalho. Para a presente discussão, tomou-se como exemplo duas reuniões assistidas durante a passagem pela fábrica.

Na primeira, estiveram presentes aproximadamente cinqüenta trabalhadores de uma seção consensualmente considerada como uma das mais insalubres e perigosas da empresa. Também participaram da reunião, cipeiros, o técnico de segurança e o supervisor da seção. Excepcionalmente, não foram apresentados filmes ou aulas, os quais foram substituídos pela apresentação do pesquisador aos operários.

Após o esclarecimento sobre a pesquisa, o supervisor seguiu falando, dentre outras coisas, sobre a preocupação com a qualidade, procurando conjugar qualidade do produto com qualidade do trabalho, que no seu entender significava manter as coisas organizadas e limpas. Depois, disse que gostaria de saber se os trabalhadores tinham algo a dizer. Os presentes fizeram três reclamações. A primeira, sobre uma escada que estava ruim e apresentava riscos. Outra, sobre a necessidade de instalação de um bebedouro perto de uma determinada prensa dentro da seção. A terceira reclamação mobilizou boa parte dos trabalhadores presentes, que por duas vezes gritaram em coro: "E o leite!!?".

Os operários daquela seção vinham, há algum tempo, reivindicando leite para tomar durante a jornada. Conforme informou um cipeiro, o início da solicitação deveu-se à concepção compartilhada pelos trabalhadores de que o leite evitaria intoxicações pela fumaça dos fornos, 
até um médico fora convidado para falar aos operários sobre o assunto e dissuadi-los dessas idéias não confirmadas pelo saber científico. O cipeiro afirmou ter conversado com os trabalhadores e disse ter sido convencido por eles de que o leite estava sendo solicitado agora como uma forma de complementação alimentar.

Esse fenômeno não se reduz à empresa estudada. Há um mito que cerca o leite e seu poder de cura. Em várias fábricas onde, por exemplo, existe a operação de pintura, o leite é oferecido pelos empregadores ou exigido pelos operários como forma de desintoxicação. Aqueles trabalhadores da Metalco conhecem os males a que estão submetidos e servem-se desse saber da cultura popular para orientar suas ações de preservação da própria saúde. Trata-se de uma genuína ação coletiva motivada pelas representações que têm sobre o adoecer. Infelizmente, o leite não tem as propriedades que acreditam ter, pois é incapaz de eliminar dos seus corpos os efeitos da insalubridade.

Durante uma outra palestra, encontraram-se novas evidências que reforçam a hipótese da adoção de um programa de segurança calcado em uma perspectiva de mudança de comportamento, cristalizada na concepção de ato inseguro. Isso fica claro com a descrição do filme educativo exibido e das conversas que lhe sucederam.

O apresentador do filme começou dizendo que os fatores mais importantes na causalidade dos acidentes eram de um certo tipo que podia ser controlado: stress, negligência, desatenção, esforço excessivo e fadiga; os três primeiros seriam de "natureza psicológica", conforme suas palavras. O stress afetaria o desempenho e o trabalhador estressado viraria uma ameaça à sua própria segurança e à de seus companheiros; mostrou-se, então, uma cena onde um trabalhador tinha a mãe e a filha doentes (um "problema fora da empresa") e por isso estava muito preocupado e tenso, em conseqüência do que se acidentou, sofrendo um choque elétrico. Quanto à negligência, o narrador enfatizou a necessidade de ter responsabilidade, as conseqüências danosas dos atos negligentes e concluiu: "Tenha cuidado ao executar suas tarefas". Em relação à desatenção, disse que essa característica, em alguns casos, fazia parte da personalidade dos indivíduos e que por isso seria muito difícil de mudar a curto prazo; em outros casos, seria devida às expectativas dos trabalhadores em conseguir acabar logo um trabalho ou realizá-lo no menor tempo possível. O esforço excessivo, da mesma forma, seria uma forma do trabalhador provar que é capaz de fazer muito e, ao comentar a história ilustrativa que apresentou, disse: "Ele devia era ter diminuído o ritmo". Finalmente, a fadiga foi apresentada como tendo origem fora do trabalho (assim como o stress): contou-se a história de uma mulher que estava exausta por causa da filha doente. Um companheiro seu disse que ela deveria tirar o dia de folga; no fim, ela não terminou o serviço de manutenção de uma bomba, não colocou um aviso alertando para os 
riscos caso esse equipamento fosse acionado e um outro colega, desavisado, acionou-o, tendo os olhos atingidos por um líquido quente e sob pressão; diante da tragédia, a recomendação do narrador foi a seguinte: "Se estiver tenso, procure a ajuda do departamento de pessoal ou de seu chefe".

Terminada a apresentação do filme, o vice-presidente da CIPA tomou a palavra e repetiu alguns dos ensinamentos proferidos, mostrando sua concordância com eles. Falou, por exemplo, que era muito comum na Metalco os trabalhadores descobrirem uma possibilidade de acidente e não avisarem os outros colegas. Essa fala - diante da intensa referência aos problemas fora da empresa, ao stress etc. - tem uma conotação diferente, pois admite o risco e reconhece a falta de comunicação como sendo um dos determinantes dos acidentes.

Depois do vice-presidente da CIPA, o supervisor do setor tomou a palavra. Em sua fala, atrelou a garantia de emprego à produtividade e qualidade, ao mesmo tempo em que conclamou os presentes a colaborarem com o sucesso da Metalco dizendo: "a empresa são os funcionários". Disse que os negócios não estavam indo bem e que, mais do que nunca, haveria contenção de verbas em todos os aspectos possíveis: economia de luz, de material de consumo e de equipamentos de proteção. Depois de uma pequena pausa, muda o sentido de seu discurso e afirma:

Não que não vá ter equipamento [de proteção individual] pra todo mundo. Vai ter equipamento pra todo mundo e todo mundo tem que usar, mas com cuidado, sem deixar óculos por ai largado, sem jogar fora a luva que ainda dá pra usar. Não vamos descuidar da segurança, mas temos que economizar [supervisor, palestra de segurança].

Prosseguindo com sua intervenção, o supervisor declarou que as causas dos acidentes de trabalho seriam as preocupações externas, o descuido e "também as condições inseguras". Em seguida, fez um apelo: quando o trabalhador tivesse um problema em casa, que ele não deixasse de conversar com seu supervisor. Em outro momento, abordou as condições inseguras: falou da existência de ferramentas velhas que não funcionavam direito e afirmou que elas deveriam ser substituídas imediatamente para evitar acidentes, pois a economia de material não poderia estar acima da segurança.

O supervisor afirmou também que, se a empresa não tivesse mais lucros, a ameaça de desemprego seria maior. Esse argumento dava força às suas exigências por economia, atenção e preocupação com a qualidade das peças fabricadas: se a qualidade não superasse a do concorrente ou se o custo final do produto fosse muito alto, a empresa perderia para os adversários e seria "obrigada" a fechar postos de trabalho. Em complementação a isso, disse:

Ou a empresa cresce ou ela fecha. O trabalhador tem que ter visão de qualidade e de custo [...] nós somos a empresa [...] somos obrigados a ter preocupações que antes não tínhamos 
[...] o cara sentado lá no banheiro [por não estar produzindo] põe em risco o emprego de muita gente [...]. [Continuou dizendo que as chefias intermediárias diminuíram e que ...] agora cada um tem que olhar a si mesmo ${ }^{43}$ [supervisor, palestra de segurança].

Outro exemplo das práticas educativas institucionalizadas presentes na Metalco é a realização anual da Semana Interna de Prevenção de Acidentes (SIPAT). Esses eventos variam de uma empresa para outra, podendo ser organizados pelas próprias equipes de segurança, pelas CIPAs ou por prestadoras de serviços contratadas para esse fim. Além dos temas ligados diretamente ao trabalho, abordam também assuntos como tabagismo e AIDS. Na Metalco, a SIPAT do ano de 1996 incluiu a apresentação da peça de teatro "O Acidente", que foi escrita, dirigida e interpretada por cipeiros eleitos.

A iniciativa de fazer a peça teve alguns antecedentes. Em 1994 uma outra peça foi apresentada por um grupo de teatro contratado. No ano seguinte, convidou-se um ator para dirigir uma peça encenada pelos trabalhadores. Motivados por essa experiência, os cipeiros decidiram fazer a próxima peça por conta própria.

Procurou-se verificar se o texto interpretado pelos trabalhadores não era uma mera reprodução das peças anteriormente montadas e obteve-se a informação, por parte do vicepresidente da CIPA, de que a peça não era baseada nas anteriores e que, pelo contrário, procurava retratar com maior proximidade a realidade do cotidiano da Metalco, o que até então não tinha sido feito.

A história relata o dia-a-dia da fábrica, as conversas entre trabalhadores, chefe e cipeiro. Narra também uma festa de fim de semana e o dia em que um acidente aconteceu.

Os personagens são: o Chefe, que está sempre cobrando produtividade dos trabalhadores, mas é compreensivo com seus subordinados e não os obriga a trabalhar em máquinas com defeitos; o cipeiro, que o tempo todo dá conselhos aos seus colegas sobre a segurança; quatro trabalhadores, com diferentes atitudes perante a segurança e dois técnicos de manutenção.

No decorrer dos diálogos são inseridas orientações a respeito da segurança no trabalho, enfatizando o cuidado a ser tomado pelos trabalhadores enquanto realizam suas atividades. Por exemplo, a música "Temos que se cuidar”, que abre a peça em ritmo de pagode, adverte:

\footnotetext{
${ }^{43}$ É interessante notar nessas falas do supervisor mais um mecanismo de responsabilização dos trabalhadores: eles passam a ser os responsáveis pela garantia de seus empregos. Devem tomar cuidado, ser caprichosos e econômicos, assumir como seus os interesses da empresa. Devem fazer isso, não pelo interesse em ganhar mais ou ter participação nos lucros, mas para não ficarem desempregados nem provocarem o desemprego de seus colegas. Não precisam mais de um chefe, essa figura está internalizada e é sustentada pelo medo de ficar sem os meios de subsistência.
} 
Olha, eu tenho que me cuidar/ para não me acidentar [...] Pare, pare pense/ Quantos acidentes/ Achamos que isso/ Nunca vai acontecer/ Com a gente, mas será?/ Não devemos vacilar/ Pra nossa família abraçar.

Mesmo na comemoração do aniversário de um dos operários a questão do cuidado com os acidentes é relembrada em um trecho da música "A festa do Carioca": "Nós precisamos conscientizar/ E não podemos nunca vacilar/ Pois vacilando no trabalho/ Você pode se acidentar".

Uma última alusão à necessidade de ter cuidado, aparece em uma referência às brincadeiras durante o trabalho: "Cipeiro: Vamos parar de brincadeiras. Vocês sabem que não se deve brincar durante o trabalho, pois pode causar grandes acidentes!".

Em seguida, uma crítica é feita às pessoas que menosprezam a importância do constante tomar cuidado. Essa fala sugere que, ao mesmo tempo, os trabalhadores subestimam os riscos e a gravidade dos acidentes que podem ocorrer:

Carioca: Que isso! A gente prestando atenção não acontece nada. É que as pessoas falam muito.

Cipeiro: Para de gracinha Carioca, não é que as pessoas falam muito, a coisa é mais feia do que você pensa.

Grandão: É isso mesmo, o Cipeiro tá certo, o negócio é pior do que se imagina [itálicos nossos].

Sugere-se também que os trabalhadores desconhecem a importância dos cuidados com a saúde:

Terra-seca: Vocês sabem que cada ferimento que tiverem, por menor que seja, temos que ir na enfermaria para fazer curativo, pois a ferida pode infeccionar e causar grandes transtornos.

Em outro diálogo, comenta-se a responsabilidade que tem o trabalhador por verificar as condições das máquinas e de não trabalhar quando elas não são adequadas, da mesma forma como nas entrevistas acima descritas:

Chefe: Pessoal, vamos parar com o papo e vamos trabalhar, pois a produção está atrasada e eu quero aumentar a eficiência da linha.

Bolinha: Chefe, como vou produzir com esta máquina dando problema direto no automático? Isto pode causar um acidente!

Chefe: Vou mandar o pessoal da manutenção dá uma olhada nesta máquina. Mas você já devia ter feito uma O.M. ${ }^{44}$ !

(O chefe sai preenchendo uma O.M. Enquanto isso, continua a conversa e algumas brincadeiras). [itálicos nossos].

Ou ainda:

${ }^{44}$ O.M.: Ordem de manutenção. 
Terra-seca: Bolinha, se você ver alguma coisa errada na máquina que possa estar pondo em risco a sua segurança, faça uma O.M. e leve até a segurança para serem tomadas as providências, e eliminar as condições inseguras.

Uma variante dessas falas encontra-se em uma intervenção do cipeiro, que referiu-se aos riscos de acidentes em escritórios. Em seu discurso, ele enfatiza a necessidade de reconhecer-se os riscos para acidentes, mas ao mesmo tempo aponta para a responsabilidade dos trabalhadores pela existência desses riscos:

Cipeiro: Minha gente, vou fazer um comentário sobre os riscos de acidentes em escritórios, pois vocês sabem que um arquivo com as gavetas abertas, usar um grampeador de forma errada, deixar o cesto de lixo no corredor, vidro quebrado sobre a mesa, subir ou descer as escadas sem usar corrimão, e outras coisinhas mais que para nós é o dia-a-dia, podem causar acidentes. Por isso gostaria de lembrar a todos, que olhassem seu ambiente de trabalho no início de sua jornada, e verificassem se existe alguma destas condições inseguras que eu acabei de falar, e corrigissem. Peço também, que alertem seus companheiros de trabalho, para que mantenham suas mesas e salas organizadas, procurando evitar acidentes desnecessários [itálicos nossos].

A preocupação da empresa com a segurança também é ressaltada:

Chefe: Graças a Deus o dia foi bom, conseguimos produzir bem e com qualidade, e o mais importante é que não tivemos nenhum tipo de acidente, pois a preocupação maior da gente são os acidentes que venham prejudicar os nossos funcionários.

Com relação ao acidente representado na peça, as explicações para ele variaram. Assim, ao mesmo tempo que os acidentes são atribuídos à distração dos trabalhadores...

Chefe: Em todas as palestras de segurança eu falo para vocês prestarem atenção no que estão fazendo, parar com as brincadeiras e as conversas, pois isso tira toda a atenção de quem está executando o trabalho. E que isso sirva de alerta para vocês.

... o acidente ocorrido vitimou justamente a pessoa mais cuidadosa:

(Enquanto o Chefe e o Grandão levam o Terra-seca para a enfermaria, o pessoal fica comentando o acidente, e ao mesmo tempo tristes pelo episódio).

Carioca: Logo o Terra-seca que é um cara que faz tudo certinho?

Cipeiro: É verdade, qualquer machucadinho lá está ele na enfermaria fazendo curativo [itálicos nossos].

O acidentado, por sua vez, reconhecendo ser cuidadoso, introduz no diálogo uma explicação de cunho fatalista, que sugere que o ato constante de tomar cuidado não é condição suficiente para evitar os acidentes:

Terra-seca: [...] Graças a Deus não aconteceu coisa pior comigo, pois sou uma pessoa cuidadosa; todos meus amigos sabem disso. Mas o acidente não escolhe hora nem lugar. Ele acontece.

A explicação fatalista é relativizada quando um outro trabalhador diz: "Podia acontecer com qualquer um de nós...”, mas em seguida completa: “...ainda bem que eu pedi para arrumar a 
máquina, se não poderia ser eu". Nesse caso, a personagem justapõe à explicação fatalista uma outra explicação, calcada nas condições inseguras como causa de acidentes.

São quatro as idéias relacionadas aos acidentes, presentes no texto da peça teatral: a distração dos trabalhadores, atrelada à obrigação de tomar cuidado; a sua responsabilidade em detectar os riscos e recusar-se a trabalhar enquanto eles existirem; as condições das máquinas que são operadas e a fatalidade.

Os dois primeiros fatores introduzem uma nuance na definição da responsabilidade dos trabalhadores e na participação de variáveis pessoais para a determinação da ocorrência dos acidentes: no primeiro, caberia ao trabalhador não introduzir novos riscos; no segundo, caberia a ele perceber os riscos existentes. Embora ambos dependam da ação individual, eles têm por trás de si explicações causais sutilmente diferentes: em um, o trabalhador é causa direta; em outro, tem papel ativo, embora solitário, na modificação de seu ambiente de trabalho. O terceiro fator, as condições inseguras, embora contradigam os fatores pessoais envolvidos na produção dos acidentes, podem aparecer como causa produzida pelos trabalhadores ou como causa inevitável, quando acompanhadas da idéia de fatalidade.

A forma como o acidente de trabalho é construído através dessa peça revelou algumas diferenças em relação aos conteúdos das outras práticas institucionalizadas, discutidas acima. $\mathrm{O}$ discurso institucionalizado presente na campanha, na apostila, no filme e nas palestras analisadas adota uma conformação ao estilo do gênero científico-didático, marcado pelo esforço retórico de aparentar coerência; a coerção desse tipo de gênero de discurso tem por conseqüência o desvanecimento das marcas explícitas da polissemia discursiva ${ }^{45}$. A peça, por tratar-se de outro gênero de discurso - roteiro teatral retratando a linguagem coloquial dos operários e, portanto, dos próprios autores - e por ter sido criada por aqueles que convivem mais proximamente com a realidade dos acidentes de trabalho, permite que se revelem mais contradições do que o gênero científico-didático. Como conseqüência, além de sintetizar os repertórios interpretativos disponíveis, revelou os mesmos deslizamentos de significado presentes nos diálogos mantidos com trabalhadores e analisados acima. Ao servir como instrumento de formação e "conscientização" dos trabalhadores, a apresentação da peça permitiu também que variações nas formas de conceber os acidentes circulassem pelos canais formais de comunicação.

Todas as atividades educativas expostas acima, especialmente as reuniões semanais de segurança, foram muito comentadas pelos trabalhadores entrevistados. Em geral, todos têm uma

\footnotetext{
${ }^{45}$ Do mesmo modo, a escrita científica, ao eliminar os pronomes da primeira pessoa, apaga as marcas do sujeito, criando a ilusão de que não se fala de nenhum lugar e a aparência de um texto sem autor, muito embora existam efetivamente um lugar ou contexto e um enunciador.
} 
bom julgamento dessas práticas educativas, ressaltando sua importância na "conscientização", no estímulo ao uso de EPI e na influência sobre o comportamento de segurança dos trabalhadores na fábrica e em casa. Para muitos, as palestras seriam uma forma de "lembrar" aos trabalhadores que os acidentes acontecem. A importância das reuniões de segurança é apontada por um entrevistado:

...tem a reunião toda semana, então, você vai tendo uma visão melhor, não é verdade? Uma hora tem que entrar na cabeça que ele tem que estar se protegendo por causa dele mesmo. Então, isso ai é que ajuda bastante. Todo dia uma reuniãozinha, todo dia o cara tá falando, explicando, um dia um fala, no outro dia outro fala, outro dia você mesmo fala na frente lá. Então, isso aí, o pessoal vai tendo mais visão da coisa que não é brincadeira [Geraldo, montador, entrevista 7].

Os efeitos das palestras sobre o uso de equipamentos de proteção individual é ressaltado por um dos entrevistados:

Bom, na minha opinião, de noventa e um pra cá, acho que melhorou bastante [P.: Tá.] Tá bem...Vixe! Melhorou noventa porcento. Só de usar o óculos todo mundo da fábrica... Já pensou, mil e duzentas pessoas, todo mundo, sem precisar chegar e falar nada, já vai pegando: "eu preciso de um protetor pra entrar aqui, um óculos, senão num...". Inclusive, antes mesmo da gente, quando a gente tá chegando na portaria, ali, que a gente vai entrar na fábrica, pára ali mesmo, já põe o óculos, o protetor... [P.: Tá, já pra antes...] Já pra antes de entrar e pra andar dentro da fábrica também. [P.: Tá.] Tá, melhorou bastante, sobre a segurança [P.: Tá.] Tá bem, pelo menos o pessoal dessa empresa tá bem conscientizado [Irineu, operador de máquina, entrevista 9].

A fala de um trabalhador revela como as palestras ajudam a reforçar o consenso em torno da dicotomia ato inseguro-condição insegura:

[P.: Deixa eu perguntar uma outra coisa que talvez você saiba. Você tá me explicando o jeito que você compreende o acidente. As outras pessoas, em geral, como que elas explicam o acidente? Como você acha que elas explicam?] Como elas explicam o acidente? [P.: Isso, porque você falou de condições inseguras, distração e tal. Que fatores você vê nas pessoas de onde você trabalha?] Eu acho que elas vão falar quase a mesma coisa e se mudar, é muita pouca coisa, que eu não sei. Eu acho que, em geral, eles vão falar isso aí, sobre condição insegura e sobre distração da pessoa que... isso aí, né, essas coisas aí, é o pensamento em geral das pessoas que trabalham aí. Porque nessas reuniões de cinco minutos de segurança, que não é cinco minutos, geralmente dá meia hora, eles batem mais na tecla disso aí. [P.: Eles quem?] O pessoal da segurança, os da CIPA [Geraldo, montador, entrevista 7].

As práticas educativas são vias privilegiadas de divulgação das idéias adotadas pela Metalco e presentes no imaginário social. Somadas a outros mecanismos sociais de difusão de uma visão estritamente psicológica dos eventos do mundo do trabalho, elas presentificam essa visão no contexto institucional e fazem hegemônico o repertório interpretativo baseado na culpa individual. Essa forma de compreensão do fenômeno exime a empresa da responsabilidade pelos acidentes e apresenta como imutável a realidade das condições de trabalho a que estão submetidos os operários. Desse modo, afasta do contexto discursivo a percepção da exploração e 
da produção social dos riscos, revelando-se - em tais circunstâncias - como uma estratégia ideológica de dominação.

No entanto, a visão dos acidentes baseada na dicotomia atos inseguros-condições inseguras traz consigo as sementes da oposição às explicações psicologizantes ou pessoais dos acidentes e sua introdução no senso comum instaura contradições - que refletem as próprias contradições vividas pelos trabalhadores em suas relações sociais - que fornecem os elementos a partir dos quais as formas de compreender os acidentes são construídas no cotidiano. Desse modo, parafraseando Billig \& cols. (1988), o trabalhador não é receptor passivo da ideologia, mas antes, é um ator social que pensa e argumenta com ela a partir de seus elementos contraditórios. Os trabalhadores, ao revelarem a polissemia de suas práticas discursivas, expressam interpretações diversas dos acidentes e estabelecem rupturas semânticas com as posições hegemônicas, na forma de contra-discursos - que são acompanhados por outras formas de resistência.

\subsubsection{Rupturas e formas de resistência}

A resistência ao discurso hegemônico - o qual está fundamentado na naturalização dos riscos e em práticas institucionais de difusão das concepções hegemônicas - está presente de diferentes formas no contexto discursivo estudado, não apenas nas falas daqueles que o questionam diretamente, mas também nas rupturas possibilitadas pela composição dilemática das explicações, que se deixa transparecer no processo de constituição dos acidentes por meio das práticas discursivas. Isso é possível, como visto acima, pela existência de dois repertórios que constroem o acidente de trabalho de modos diferentes, a partir da oposição entre atos inseguros e condições inseguras.

Como aponta Laurell (1984), as formas e o vigor que as resistências operárias irão assumir estão condicionados pelo momento histórico e político em que se manifestam: em alguns momento podem ser quase nulas ou assumir formas muito sutis, em outros, expressarem-se através de movimentos coletivos articulados.

No caso dos discursos estudados, a manifestação de uma oposição frontal às concepções calcadas no conceito de ato inseguro apareceu nas falas de alguns poucos entrevistados, que reconheciam a sua predominância e os mecanismos institucionais de sua difusão. A percepção dessa predominância revela-se, por exemplo, no comentário feito por esse trabalhador a respeito dos encarregados:

[P.: Mas com relação a esse, esse acidente porque, porque você acha que aconteceu esse acidente com você? O que que causou esse acidente?] Ah, na verdade acho que, pode ser um 
descuido meu, pode ser uma falha também dá, dá... desse gancho, né, inclusive eu cobrei depois do pessoal que ele era muito curto. Na verdade, ele joga sempre a culpa no operador, mas nem sempre é, porque... [P.: Quem joga a culpa no operador?] Ai seria, no caso, o encarregado, né... [Caetano, operador de máquina, entrevista 3].

$\mathrm{Ou}$, ainda, neste outro exemplo, em que o entrevistado aponta para a existência de uma distorção nas análises de acidentes realizadas pelos técnicos de segurança:

Eu falei "ato inseguro" porque muitas vezes não é, e os técnicos só coloca ato inseguro. [P.: Ah, Entendi! Tá!] Eu não sei se é uma matéria de ludibriar alguém, algum relatório que vai pro Estados Unidos ${ }^{46}$... [P.: Certo.] Parece que vai, eu nem... [P.: Vai.] Cê sabe? [P.: Sim.] Ou alguma coisa, porque não é possivel, tudo, tudo, tudo é ato inseguro! [P.: Tá.] O cara cai de lá, ato inseguro... [P.: Tá, entendi.] Cê tá entendendo? [P.: certo.] Eu questionei muito esse negócio de ato inseguro, nunca assinei nada. Porque, cipeiro tem que assinar também. [P.: Certo.] Eu não assinava! [Marcelo, operador de máquina, entrevista 12].

Esse mesmo entrevistado disse reconhecer nas palestras um mecanismo de difusão das idéias que culpabilizam os trabalhadores pelos acidentes, atribuindo-os a atos inseguros:

Eu acho que é tipo, é matéria de conscientização, sabe? Se você, igual à palestra deles... tipo a palestra deles, a matéria é sobre isso. [P.: Sobre o quê?] Sobre ato inseguro... sabe, eles só falam isso. Então, uma pessoa que, tipo, trabalha aqui ou sempre fica vendo isso, fica bitolado, porque a pessoa não vê o outro lado, sabe? [...] Então, o que você vê é que a firma, ela sempre é que fala que é o operário que faz ato inseguro... e, eu acho, é uma coisa que a pessoa fica bitolada: "é ato inseguro, é ato inseguro, é ato inseguro...". [P.: Tá.] Porque, sei lá, eu acho que tinha que alcançar mais, tinha que ver mais longe esquecer...Tudo bem, isso aqui é bom. Você... mas também tem muita gente que vai só pra ficar mais descansado, né, nessas reuniões aí. Porque são uns vídeo muito ultrapassado, não são as coisas de hoje em dia. Pô! Tem máquina aí, se você não pisar, não fecha, não trava, não liga, não vai fazer a operação. [P.: Tá.] Ou seja, tem quatro sistema de proteção do operário e aqui, você vê, não tem muitas. [P.: Tá.] Se escapa, tipo, uma tampa aqui... Tu morre, cara! Então, é isso, eu acho que o pessoal, em matéria de ato inseguro, é por causa dessa palestras, essas coisas visando sempre culpar o operador [Marcelo, operador de máquina, entrevista 12].

Algumas expressões de resistência também foram encontradas em um pequeno número de fichas de acidentes, nas quais os trabalhadores acidentados, ao responderem à pergunta "por que cometeu ato inseguro?", discordam indignados dessa responsabilidade que lhes é imputada ou indicam determinadas condições inseguras presentes na produção dos acidentes que sofreram, que os explicariam mais satisfatoriamente, em sua opinião. Ou, ainda, nas fichas de acidentes que fazem referência a atos inseguros, mas não são assinadas por cipeiros, que não concordavam com tais conclusões.

Pode-se falar também de resistências silenciosas ou rupturas de significado que acontecem no próprio processo de construção das explicações dos acidentes, quando, por exemplo, fala-se da obrigação que tem o trabalhador de recusar-se a trabalhar. Embora essa

\footnotetext{
${ }^{46}$ Como já foi dito, a Metalco é subsidiária de uma matriz norte-americana, a qual estabelece, dentre outras coisas, metas de segurança.
} 
autonomia seja ilusória, ela desponta no horizonte de mudanças como uma resistência em potencial que certamente depende de outros fatores para concretizar-se, mas que habita o imaginário dos trabalhadores como uma ação possível. Esse tipo de ruptura também está presente nos modos de explicação que, embora não encontrem nas causas ambientais os principais determinantes dos acidentes, apresentam-nas em segundo plano.

Por outro lado, alterações nas condições de produção dos discursos têm introduzido pequenas mudanças nas formas de percepção dos riscos. Diversos acontecimentos ocorridos na Metalco produziram algo que poderíamos denominar de efeito desnaturalizador. Sua principal conseqüência é a ampliação do horizonte de possibilidades de mudanças das condições de trabalho. Vejamos alguns exemplos.

A introdução de talhas para o transporte de peças de peso elevado no setor de montagem diminuiu consideravelmente o número de acidentes envolvendo prensamento de dedos e mãos e mostrou aos trabalhadores que certos riscos que pareciam fazer parte da natureza de sua atividade de trabalho poderiam ser eliminados com a simples introdução de melhoria técnicas. Assim, muitos trabalhadores referem-se às talhas como uma nova forma de evitar acidentes durante a manipulação de peças pesadas e reivindicam sua instalação em setores em que ainda não existem. Da mesma forma, diversos acidentes ocorridos tiveram o poder de revelar riscos que antes não eram percebidos como tais ou, pela sua gravidade, sensibilizaram os trabalhadores, que passaram a reivindicar correções ambientais.

O discurso sindical, pela sua ênfase nas mudanças ambientais e no caráter político da implementação dessas mudanças, também aparece como contraponto à naturalização dos riscos. Através de seus diretores de base, dos jornais distribuídos nos portões da fábrica que denunciam más condições de trabalho e apresentam os resultados de negociações de melhorias, dos pronunciamentos em greves, as idéias sindicais chegam aos trabalhadores também na forma de um contra-discurso e difundem-se pelos canais informais de comunicação.

Há ainda um outro tipo de ruptura semântica com a qual nos deparamos durante a estada em campo. O discurso heinrichiano - que orienta as práticas institucionais voltadas para os acidentes de trabalho, que é compartilhado por todos na empresa e que fornece os elementos para a composição de repertórios opostos - tem sofrido sérios desafios que poderão modificar sua posição na Metalco. Esses desafios têm sido impostos por um novo modo de encarar os acidentes que aos poucos vem sendo introduzido na empresa: a abordagem sistêmica, representada pelo método da árvore de causas. Esse fenômeno é restrito à equipe de segurança, isto é, não há marcas da presença desse discurso nas falas dos trabalhadores, mas, a depender do sucesso de 
sua inserção e das mudanças que produzir, poderá afetar os modos comuns de pensar os acidentes de trabalho a longo prazo.

O que interessa notar aqui é a forma como o discurso hegemônico reage às investidas do novo referencial e o que revela de si mesmo ao fazer isso. A análise desse enfrentamento é útil para a compreensão da retórica do modelo heinrichiano, pois a tentativa de implantar um novo discurso no território por ele habitado, provoca distorções que revelam as suas formas de operar.

O discurso sistêmico aparece na empresa por duas vias. Através de um técnico de segurança que nos últimos tempo vem se interessando pelo assunto e, principalmente, através das exigências da matriz norte-americana para que o método seja implementado. As recomendações feitas por uma auditoria internacional e a perspectiva de mudança na legislação - que poderá passar a exigir que essa metodologia seja aplicada em todas as empresas - motivaram a equipe de segurança a elaborar uma apostila sobre as árvores de causas.

A auditoria elaborou um relatório no qual, após elogiar o detalhismo das investigações de acidentes feita na fábrica, sugeriu a utilização do método de árvore de causas. Conforme o relatório:

A empresa tem uma excelente forma de investigação de acidentes, que registra informações detalhadas para "quem, o que, quando e onde", mas apenas mostra as razões imediatas para $o$ acidente [...] Recomenda-se que a equipe de segurança e supervisores sejam treinados na "Root cause analysis" ou na versão de CIPA da "Árvore de causas". Isso permitirá à empresa: analisar a verdadeira razão para o acidente, fazer recomendações para correção e compartilhar a informação com os empregados, a fim de evitar ocorrências similares no futuro. [itálicos nossos].

Deve-se notar que essa auditoria - que analisou todos os procedimentos de segurança adotados na empresa e fez diversas sugestões, desde a fixação em todos os aparelhos telefônicos de um número de emergência, até a normatização da manipulação de substâncias químicas - não condenou a utilização dos conceitos de Heinrich nas fichas de acidentes, mas apenas apontou a limitação da análise às causas imediatas, deixando de lado a principal bandeira da abordagem sistêmica dos acidentes, que é justamente a recusa a adotar concepções individualizantes que não buscam causas, mas $\operatorname{culpados}^{47}$ (Vidal, 1991). Sendo solicitação de instância superior, a implantação do método estava sendo providenciada com prioridade.

Porém, essa nova forma de pensar o acidente é totalmente estranha à "cultura" da empresa, da mesma forma que a apostila confeccionada não corresponde às práticas de setor de

\footnotetext{
${ }^{47}$ A abordagem sistêmica, embora avance em relação à compreensão da produção dos acidentes, ainda não considera seus determinantes sociais e históricos.
} 
segurança no trabalho, o que vem ocasionando sobreposições semânticas nos discursos de engenheiros, técnicos e cipeiros, comentadas abaixo.

Em uma conversa com um técnico de segurança e um cipeiro eleito, observou-se um exemplo da tentativa de integrar os dois modelos acidentológicos ou, antes, de preservar alguns conceitos do modelo antigo. Discutiam-se alguns trechos da nova apostila de análise de acidentes, dentre eles a seguinte frase: "Fator humano - Não é causa de acidente de trabalho, é indicador de falha no sistema". Houve concordância entre os presentes a respeito da assertiva. O técnico de segurança, apesar de acreditar que o conceito de ato inseguro estava ultrapassado, disse que "o ato inseguro até existe, mas o trabalhador não deve ter medo de dizer que cometeu um", pois ele significaria apenas uma falha no sistema e não uma responsabilidade dele. Procura, então, as "causas" do ato inseguro, os seus antecedentes, especialmente em variáveis incomuns presentes na ocasião do acidente. O cipeiro, por sua vez, não parecia ter uma posição clara sobre o método. Disse apenas que o achava interessante e que, apesar de não estar ainda sendo usado na empresa, a sua "lógica" já estava presente nas análises feitas pelos técnicos e registradas nas fichas de acidentes. Ambos ressaltaram, ainda, as dificuldades de aprendizagem da técnica e de aceitação de uma nova visão sobre os acidentes por parte dos trabalhadores, o que dificultaria a sua ampla adoção ${ }^{48}$.

Em outra conversa com essas mesmas pessoas, o cipeiro disse que, no método de árvore de causas, a culpa do acidente era sempre atribuída aos supervisores, em função de algo que eles deixaram de fazer ou que fizeram errado. Esse mesmo cipeiro mostrou-se temerário em utilizar o método, afirmando que só iria começar “...quando tiver um bom curso para aprender a fazer bem feito".

Note-se como o conceito de "ato inseguro" e a noção de "culpa" são preservados nesses diálogos e contemporizados com a busca por antecedentes mediatos dos acidentes. A idéia de que as análises registradas nas fichas trazem a "lógica" das árvores de causas também exemplifica esse sincretismo teórico, pois elas têm dois campos importantes a serem preenchidos com informações coletadas pelos técnicos: os atos inseguros cometidos e as condições inseguras presentes no momento do acidente.

Quanto à permanência desses conceitos na ficha de acidentes, um outro técnico de segurança falou da forma bastante inusitada pela qual questiona os conceitos heinrichianos,

\footnotetext{
48 Sobre a primeira dificuldade, um comentário deve ser feito. A própria explicação baseada no reducionismo psicológico tem a sua complexidade, podendo até ser tão complexa quanto aquela que se pretende ensinar e, no entanto, são todos muito bem versados nela. É claro que há todo um substrato cultural e institucional que sustenta a explicação psicologizante, mas é inegável que ela contemporiza diversos elementos distintos e distantes entre si, por exemplo, a falta de dinheiro para pagar uma conta e a distração diante da máquina.
} 
tomando por base o novo método. Ele disse considerar ultrapassada a divisão entre atos inseguros e condições inseguras. Foi-lhe então perguntado por que razão os dois conceitos permaneciam nas fichas de acidentes. Ele respondeu:

Porque a gente não vai por lá na ficha que o cara brigou com a mulher, que ele tá passando necessidade em casa e que por isso tava nervoso, se distraiu e se acidentou. Não dá pra por isso lá, isso é coisa pessoal do funcionário [...] aí a gente tem que por mesmo o que era ato inseguro e o que era condição insegura que tinha na hora que aconteceu o acidente [técnico de segurança do trabalho, conversa informal].

A análise que esse técnico faz revela uma faceta do que ele compreende como sendo atos inseguros e, ao mesmo tempo, demonstra sua tentativa de vislumbrar causas a partir de antecedentes não imediatos ao acontecimento da lesão - embora fale de um tipo de antecedente inteiramente ligado à esfera pessoal e totalmente desvinculado da realidade fabril (conflito conjugal e carências ligadas à baixa renda), isto é, cria uma teoria para os atos inseguros baseada nos acontecimentos da vida não-laboral do trabalhador. Por outro lado, revela também um tipo de "ética", na medida em que considera importante não invadir a privacidade dos operários para investigar as "razões" de seus supostos "atos inseguros".

A abordagem sistêmica, embora haja pressões para ser implantada, está longe de ter uma influência importante nas formas de percepção dos acidentes, não passando de um discurso destoante e de difícil vinculação ao primeiro. Além disso, a tentativa de introdução de um novo modelo de compreensão dos acidentes revela quão profundamente a visão hegemônica está enraizada nas formas de apreensão da realidade dos membros dessa empresa, de modo que as propostas do método de árvore de causas são interpretadas à luz da dicotomia atos inseguroscondições inseguras.

Como vimos, são diversas as maneiras pelas quais rupturas semânticas e formas de resistência manifestam-se no contexto discursivo estudado. Por um lado, as concepções heinrichianas sofrem deslocamentos de significados, ora pela ativação de suas contradições nas práticas discursivas, ora pela introdução de outros discursos - como o sindical ou o das árvores de causas - ora pelos acontecimentos dotados de um efeito desnaturalizador. Por outro, essas rupturas muitas vezes constituem contra-discursos que podem ou não se expressar em práticas de resistência às concepções que reduzem a explicação dos acidentes aos fatores individuais e estritamente psicológicos.

Feita a exposição dos resultados do trabalho de campo, teceremos alguns comentários sobre os contextos delimitados para a realização desta pesquisa, procurando articular a modulação dos conteúdos do imaginário social pelo contexto institucional e a ação 
argumentativa, baseada em lugares-comuns, através da qual esses conteúdos revelam sua polissemia e são ativados para lidar com situações dilemáticas.

\subsection{Modulação, lugares-comuns e polissemia}

Das concepções sobre os acidentes de trabalho construídas no interior da acidentologia e da psicologia, a Teoria dos Dominós de Heinrich foi aquela que revelou maior influência nos discursos e práticas estudados. A presença marcante desse modelo nas formas locais de compreensão dos acidentes deve-se, em grande parte, à sua ampla difusão pelo Estado nas décadas de setenta e oitenta, conforme apontou Santos (1991), o que também está relacionado com todas as outras formas de culpabilização que o antecederam, como o conceito de "propensão a acidentes", comentado no capítulo anterior.

Quanto às outras teorias acidentológicas, a abordagem sistêmica - embora não esteja presente nos discursos dos trabalhadores (a não ser entre os cipeiros, por terem maior contato com a equipe de segurança) - aparece de forma ainda embrionária nas tentativas de implantação do método de árvore de causas. Por sua vez, a idéia de propensão a acidentes revela-se de forma muito sutil, em algumas afirmações sobre trabalhadores que, por serem supostamente mais distraídos ou mais negligentes, sofreriam mais acidentes que os outros. Entretanto, é a teoria heinrichiana que constitui efetivamente os modos comuns de pensar os acidentes de trabalho e impõe sua forma às outras concepções advindas do meio social. Assim, como vimos, o conceito de atos inseguros e a noção de culpa convivem com a busca por antecedentes mediatos dos acidentes, embora culpa e atos inseguros não tenham espaço algum em uma visão sistêmica, já que reduzem a compreensão do fenômeno à ação única e linear de um dos elementos envolvidos no processo. Do mesmo modo, a idéia de propensão foi integrada à de ato inseguro, não havendo distinção entre elas nos discursos.

Essas adaptações de conceitos vindos de outros modelos teóricos, de domínio público, aos moldes da dicotomia atos inseguros-condições inseguras e os procedimentos institucionalizados de enfrentamento dos acidentes de trabalho são a expressão daquilo que se denominou acima de modulação, isto é, a tradução dos conteúdos do imaginário social para o contexto institucional.

A teoria heinrichiana está em quase toda parte, dos métodos de análise de acidentes e fichas de registro às palestras e conversas informais. Ela fornece os elementos para a formulação de duas posições opostas em relação ao fenômeno, a partir da referida dicotomia - que é sua 
peça-chave. Assim, é essa contradição fundamental que reflete nos discursos a vivência dilemática dos acidentes de trabalho.

Em outras palavras, o modelo heinrichiano está nas práticas discursivas como um conjunto de lugares-comuns que dão forma aos debates sobre as causas dos acidentes de trabalho e aos argumentos que sustentam os repertórios interpretativos disponíveis.

Nesses debates configuram-se diversas forma de atribuição de significados. É dessa maneira que os acidentes de trabalho são construídos discursivamente, isto é, sua integração em um campo semântico é feita - pela ação conjunta das pessoas em um contexto interacional argumentativo - a partir da ativação e combinação de conteúdos dos imaginários social e institucional, dando origem a diferentes significados da expressão "acidente de trabalho" ou, dito de outro modo, permitindo a polissemia.

A polissemia discursiva convive com os efeitos do processo de naturalização dos riscos e das práticas institucionalizadas de difusão de idéias que responsabilizam os trabalhadores pelos acidentes. Assim, ao mesmo tempo que o discurso hegemônico busca sua manutenção, observam-se deslizamentos semânticos que ocasionam rupturas com as idéias dominantes e, como vimos, podem desdobrar-se em ações de resistência.

Se pensarmos a naturalização e os mecanismos institucionais como acontecimentos ocorridos no interior de relações de poder, podemos interpretá-los como uma contribuição à economia de capital constante (García, 1989) - já que a intervenção sobre os fatores humanos supostamente produtores de acidentes dispensa mudanças em máquinas e equipamentos - e a manutenção de um determinado estado de coisas, pois revestem-se de características conservadoras. Nesse sentido, a presença ubíqua de explicações psicologizantes, a naturalização dos riscos e os mecanismos institucionais de difusão apresentam-se articulados como uma estratégia de dominação, revelando sua função ideológica.

A ação de dar sentido ao acidente de trabalho também tem por conseqüência a produção de diferentes identidades. Quanto a isso, Spink (1996a) afirma que

...dar sentido é sempre e concomitantemente uma produção discursiva do $e u$. Em outras palavras, quando focalizamos as práticas discursivas, também estamos diante da processualidade da construção de identidades [p. 3].

Essa processualidade revela-se no contexto estudado pela existência de dois estereótipos: o trabalhador que está sempre atento a tudo, que não brinca, que supostamente tem autonomia para decidir parar de trabalhar, que sabe separar a vida em casa da vida na empresa, "que é consciente" e o trabalhador distraído, desatento, negligente, preguiçoso, que brinca, que não se preocupa, que "não tem consciência". É no posicionamento entre esses dois tipos extremos que 
se constroem as identidades dos trabalhadores estudados em relação aos acidentes de trabalho. De certo modo, então, dizer que se é cuidadoso é uma forma de aproximar-se do estereótipo institucional e socialmente valorizado. 


\section{CONCLUSÕES}

A presença das idéias psicológicas nos meios especializados assumiu diferentes formas ao longo deste século no Brasil, a começar pelo nascimento na medicina das "ciências do comportamento", passando pelas práticas preventivas preconizadas pelo regime autoritário e sobrevivendo nos dias de hoje, fora da academia, nos discursos de profissionais que atuam diretamente nas empresas e cuja formação ainda traz as marcas dessa forma de pensar. As idéias produzidas no interior da acidentologia e da psicologia difundiram-se pelo pensamento do senso comum. Essas idéias não estão aí por acaso, sua difusão ocorre em um contexto social e histórico determinado, que permitiu e condicionou seu aparecimento.

Colocada acima de outras formas de interpretação do fenômeno, a visão psicologizante dos acidentes - ao isentar as condições de trabalho da responsabilidade pela sua ocorrência e ao naturaliza-las - culpabiliza os trabalhadores, funcionando como uma estratégia ideológica de dominação e legitimação.

Como essa ampla difusão levaria a supor, confirmou-se a presença das teorias construídas nos meios especializados em um estudo de caso. Na empresa investigada, os acidentes de trabalho são discursivamente construídos a partir de lugares-comuns extraídos de conceitos da Teoria dos Dominós de Heinrich. Essa teoria estrutura tudo o que é dito e feito a respeito dos acidentes e engloba outros modelos trazidos da acidentologia, como, por exemplo, a abordagem sistêmica, que vem aos poucos sendo introduzida entre os profissionais da equipe de segurança. A presença da teoria Heinrichiana se faz sentir no uso dos conceitos de ato inseguro e condição insegura, na redução da análise dos acidentes aos fatores imediatos e na busca pela causa decisiva sem a qual o acidente não teria ocorrido. A definição da causa suficiente e necessária é feita a partir de um modelo no qual se decide pelos atos inseguros ou pelas condições inseguras, a depender de quem ou de que partem ações inesperadas: dos trabalhadores ou das máquinas, equipamentos etc.

Assim, essa teoria fornece as bases para duas formas compartilhadas de conceber os acidentes de trabalho, a primeira, centrada em fatores individuais e psicológicos e a segunda, em fatores ambientais. Existem, assim, dois repertórios interpretativos dos acidentes de trabalho de que dispõem todos os envolvidos para dar sentido ao fenômeno.

Essa produção de sentido acontece em meio a um intenso debate no qual a disputa entre as posições opostas estabelece um contexto argumentativo. É através da oposição e da 
argumentação entre essas posições e da experiência cotidiana dos trabalhadores que as explicações para os acidentes são construídas no interior das práticas discursivas. Dessa contradição fundamental, derivam outras que complementam a tessitura semântica que confere diferentes significados ao fenômeno.

O repertório predominante na definição das causas dos acidentes é o repertório dos atos inseguros. Distração e negligência são as principais causas atribuídas aos acidentes pelos membros da empresa, embora não sejam expressos com conotação de intencionalidade. A predominância desse conjunto de idéias é fortalecida por um fenômeno que se denominou de naturalização dos riscos e por práticas institucionalizadas de difusão das idéias dominantes. A naturalização dos riscos faz com que as condições inseguras de trabalho apareçam como naturais e imutáveis. As práticas institucionalizadas de difusão - campanhas, apostilas, cursos, filmes, palestras, semanas de prevenção - enfatizam à exaustão a responsabilidade que os trabalhadores teriam pelos acidentes de trabalho.

No entanto, não é sem resistência que essas idéias são aceitas, pois a elas opõem-se rupturas semânticas e ações de resistência. Essas rupturas e ações derivam do caráter dilemático do processo de dar sentido ao acontecimento dos acidentes decorrente da existência de posições opostas e da vivência de acontecimentos que, ao serem integrados ao campo semântico, têm um efeito desnaturalizador. Embora ainda incipientes, essas formas de resistência devem ser o ponto de partida para qualquer reflexão transformadora, pois têm as sementes para a construção de um contra-discurso que pode fazer frente à psicologização e à culpabilização, a depender das condições sociais e históricas que venham a ser produzidas.

\subsection{Implicações para o movimento sindical e as políticas públicas}

Desde o início da realização desta pesquisa, considerou-se que o valor de seus resultados seria multiplicado se pudéssemos contribuir não só para a compreensão da construção discursiva dos acidentes de trabalho e para a crítica das concepções psicologizantes, mas também para o aprimoramento de práticas sociais de enfrentamento do problema identificado.

Se é razoável supor que a visão heinrichiana compõe os modos comuns de compreensão dos acidentes de trabalho de muitas outras empresas, essa possível predominância aponta para a necessidade de difusão de modelos que se oponham a ela. É fundamental a crítica ao conceito de atos inseguros e à conseqüente responsabilização dos trabalhadores pelos acidentes de que são vítimas. Entretanto, na elaboração de políticas educativas públicas ou sindicais de educação de trabalhadores e especialistas em higiene e segurança, deve-se levar em conta que, ao serem 
introduzidas em um contexto institucional, os novos modelos sofrem um processo de adaptação às concepções dominantes naquele contexto. Assim, a possibilidade de mudança dessas concepções está na exploração de suas contradições e na elaboração, a partir destas últimas, de argumentos que revelem suas implicações para a explicação dos acidentes e para as relações sociais vigentes.

Da mesma forma, deve ser atacado o processo de naturalização dos riscos, através da historicização das condições de trabalho, da divulgação de exemplos de intervenções bem sucedidas e da elaboração de propostas governamentais e sindicais consistentes de mudanças dos ambientes de trabalho.

Embora campanhas possam servir a esse propósito, a formação de agentes multiplicadores - nos moldes das ações em saúde pública - em cursos com pequenos grupos apresentará resultados provavelmente mais satisfatórios, tendo em vista que esse procedimento favorece a reflexão e a construção coletiva de argumentos úteis nas negociações cotidianas em torno das causas dos acidentes e da existência de riscos.

Quanto à análise de acidentes, as técnicas que envolvem a participação dos trabalhadores devem ser incentivadas e aprimoradas de modo a contextualizar os discursos dos trabalhadores (considerando os dilemas discursivos ou criando situações de confronto para que a complexidade de seu pensamento seja percebida). Desse modo, nos procedimentos de análise de acidentes feitas pelo serviço público e pelos sindicatos, deve-se incluir conversas com trabalhadores em que os acidentes sejam debatidos de forma mais longa do que apenas o preenchimento de um check-list, o que estaria mais próximo dos moldes do modelo operário italiano. 


\section{BIBLIOGRAFIA}

1) Achcar, (1989). O Acidente de Trabalho e a sua Representação. Psicologia: Teoria e Pesquisa, 5 (3): 253-267.

2) Arouca, A. T. (1975). Contribuição à Análise Epidemiológica dos Acidentes de Trânsito, tese de doutorado, Departamento de Medicina Preventiva e Social da Faculdade de Ciências Médicas da Universidade Estadual de Campinas.

3) Bakhtin, M. (V.N. Volochínov, 1992). Marxismo e Filosofia da Linguagem: Problemas do Método Sociológico na Ciência da Linguagem, São Paulo: Hucitec.

4) Barjonet, P.E. (1980). Influence Sociale et Représentation des Causes de l'Accident de la Route. Le Travail Humain, 43 (2): 243-251.

5) Barreto, J.B. (1929). Prevenção dos Accidentes de Trabalho. Archivos de Hygiene, 3 (2): 243-264.

6) Bertolli-Filho, C. (1993). Medicina e Trabalho: As "Ciências do Comportamento" na Década de 40. Revista de História, n 127/128: 37-51, ago-dez/92 a jan-jul/93.

7) Billig, M. (1987). Arguing and Thinking: A Rhetorical Approach to Social Psychology, Cambridge: Cambridge University press.

8) Billig, M. (1991). Ideology and Opinions: Studies in Rhetorical Psychololgy, Londres: Sage.

9) Billig, M.; Condor, S.; Edwards, D.; Gane, M.; Middleton, D. \& Radley, A. (1988). Ideological Dilemmas: A Social Psychology of Everyday Thinking, Londres: Sage.

10) Binder, M.C.P. \& cols. (1994). A Construção da Culpa. Trabalho \& Saúde, 14 (37): 15-17.

11) Borja, C.L. \& Martínez, L.M. (1991). Motivación para la Seguridad de los Trabajadores y Incidencia del Stress en la Siniestralidad del Sector de la Construcción. MAPFRE Seguridade, 44: 23-29.

12) Brody, J.G. (1988). Responses to Collective Risk: Appraisal and Coping Among Workers Exposed to Occupational Health Hazards. American Journal of Community Psychology, 16 (5): 645-663.

13) Caplan, N. \& Nelson, S.D. (1973). On Being Useful: The Nature and Consequences of Psychological Research on Social Problems. American Psychologist, 28 (3): 199-211.

14) Carmo, J.C.; Almeida, I.M.; Binder, M.C.P.; Settimi, M.M. (1995). Acidentes do Trabalho. In: R. Mendes (org.) Patologia do Trabalho, Rio de Janeiro: Atheneu, capítulo 18, p. 431-455.

15) Chaui, M.S. (1990). O que é Ideologia, São Paulo: Brasiliense, 31ª edição.

16) Cohn, A.; Karsh, U.S.; Hirano, S. \& Sato, A.K. (1985). Acidentes de Trabalho: Uma Forma de Violência, São Paulo: Brasiliense, CEDEC.

17) Crawford, R. (1977). You Are Dangerous to your Health: The Ideology and Politics of Victim Blaming. International Journal of Health Services, 7 (4): 663-680.

18) Davies, B. \& Harré, R. (1990). Positioning: The Discursive Production of Selves. Journal for the Theory of Social Behaviour, 20 (1): 43-63. 
19) Dejours, C. (1988). A Loucura do Trabalho: Estudo de Psicopatologia do Trabalho, São Paulo: Cortez-Oboré, $3^{\mathrm{a}}$ edição.

20) Dela Coleta, J.A. (1976). A Importância da Seleção e do Treinamento do Trabalhador na Prevenção de Acidentes. Revista Brasileira de Saúde Ocupacional, 16 (4): 48-51.

21) Dela Coleta, J.A. (1980). Atribuição de Responsabilidade por um Acidente - Estudo Exploratório. Arquivos Brasileiros de Psicologia, 32 (1): 95-128.

22) Dela Coleta, J.A.; Mello e Silva, L.H.L.; Freitas, L. \& Peters, L.R. (1986). As Causas dos Acidentes de Trabalho para Operários Acidentados e Não Acidentados, Chefias e Supervisores de Segurança. Revista Brasileira de Saúde Ocupacional, 14 (53): 42-51.

23) Dionne-Proulx, J. (1992). La Perception du Danger: Une Approche Nouvelle d'Identification et d'Intervention en SST. Revue Européenne de Psychologie Appliquée, 42 (4): 297-304.

24) Dwyer, T. \& Raftery, A.E. (1991). Industrial Accidents are Produced by Social Relations of Work: A Sociological Theory of Industrial Accidents. Applied Ergonomics, 22 (3): 167-178.

25) Dwyer, T. (1989). Acidentes do Trabalho: Em Busca de uma Nova Abordagem. Revista de Adminstração de Empresas, 29 (2): 19-31, São Paulo.

26) Edwards, D. \& Potter, J. (1992). Discursive Psychology, Londres: Sage.

27) Ferreira, A.B.H. (1986). Novo Dicionário da Lingua Portuguesa - Aurélio, Rio de Janeiro: São Paulo.

28) Freitas, E. (1974). A Contribuição da Psicologia à Prevenção dos Acidentes de Trabalho. Arquivos Brasileiros de Psicologia Aplicada, 26 (1): 25-31.

29) García, J.C. (1989). A Categoria Trabalho na Medicina. In: E.D. Nunes (org.) Juan Cesar García: Pensamento Social em Saúde na América Latina, São Paulo: Cortez, p. 100-124.

30) Gergen, K.J. (1985a). The Social Constructionist Movement in Modern Psychology. American Psychologist, 40 (3): 266-275.

31) Gergen, K.J. (1985b). Social Psychology and the Phoenix of Unreality. In: S. Koch \& D.E. Leary (orgs.) A Century of Psychology as Science, Nova Iorque: McGraw-Hill, p. 528-557.

32) Gergen, K.J. (1989). Social Psychology and the Wrong Revolution. European Journal of Social Psychology, 19: 463-484.

33) Grimberg, M. (1988). La Construccion Social de La Salud-Enfermedad en Trabajadores de La Industria Grafica. Etnia, 33: 33-50, jul/dez, Alavarría-Buenos Aires.

34) Grimberg, M. (1991). Tradición Obrera y "Cultura Somática" entre los "Gráficos". El Procesamiento Colectivo de un Saber sobre la Relación Trabajo-Salud. Cuadernos Médicos Sociales, Rosário, 57: 55-63.

35) Guareschi, P.A. (1995). O Espaço da Ideologia na Psicologia. Psico, 26 (2): 45-64, Porto Alegre.

36) Heinrich, H.W. (1959). Basic Philosophy of Accident Prevention. In: Industrial Accident Prevention: A Scientific Approach, Nova Iorque: Mac Graw Hill, capítulo 2, p. 13-39, $4^{\mathrm{a}}$ edição.

37) Hirano, S.; Redko, C.P. \& Ferraz, V.R.T. (1990). A Cidadania do Trabalhador Acidentado: (Re)Conhecimento do Direito aos Direitos Sociais. Tempo Social, Revista de Sociologia da USP, 2 (1): 127-150. 
38) Ibáñez, T. (1993). Construccionismo y Psicología. Revista Interamericana de Psicología, 28 (1): 105-123.

39) Ibáñez-Gracia, T. (1993). La Dimension Politica de la Psicologia Social. Revista Latinoamericana de Psicologia, 25 (1): 19-34.

40) Laurell, A.C. (1982). La Salud-enfermedad como Proceso Social. Revista Latinoamericana de Salud, 2: 7-25, México.

41) Laurell, A.C. (1984). Ciencia y Experiencia Obrera: La Lucha por la Salud em Italia. Cuadernos Politicos, 41: 63-83.

42) Leplat, J. \& Cuny, X. (1983). Introdução à Psicologia do Trabalho, Lisboa: Fundação Calouste Gulbenkian.

43) Leplat, J. (1984). Occupational Accident Research and Systems Approach. Journal of Occupational Accidents, 6: 77-89.

44) Lima, F.N. (1976). A Prevenção de Acidentes nas Empresas de Pequeno Porte. Revista Brasileira de Saúde Ocupacional, 16 (4): 64-70.

45) Martín-Baró, I. (1983). Acción y Ideología - Psicología Social desde Centro America, El Salvador: UCA Editores.

46) Martín-Baró, I. (1989). Psicología Politica del Trabajo en America Latina. Revista de Psicología de El Salvador, 8 (31): 5-25.

47) Marx, K. \& Engels, F. (1993). A Ideologia Alemã, São Paulo: Hucitec, 9a edição.

48) McKenna, F.P. (1983). Accident Proneness: A Conceptual Analysis. Accident Analysis \& Prevention, 15 (1): 65-71.

49) Minella, L.S. (1993). Diferenças de Enfoque Sobre os Acidentes de Trabalho e suas Contribuições Teórico-Metodológicas. Revista Brasileira de Saúde Ocupacional, 21 (78): 61-77.

50) Montero, M. (1989). El Estudio Psicologico de la Ideología: Revelar u Ocultar. Boletin de AVEPSO, 12 (1-2): $28-45$.

51) Montero, M. (1990). La Psychologie Politique Latino-Americaine: Une Discipline du Social. Psychologie Française, 35 (2): 105-114.

52) Montero, M. (1995). Estratégias Discursivas Ideológicas. In: S.T.M. Lane \& B.B. Sawaia (orgs.) Novas Veredas da Psicologia Social, São Paulo, Brasiliense-Educ.

53) Montero, M. (1996). Paradigmas, Corrientes y Tendencias de la Psicologia Social Finisecular. Psicologia \& Sociedade, 8 (1): 102-119.

54) Münsterberg, H. (1913). Psychology and Industrial Efficiency, Nova Iorque: Arno Press (reimpresso em 1973).

55) Murakoshi, T. (1995). Como Reduzir Drasticamente os Acidentes com Técnicas Comportamentais, mímeo.

56) Oddone, I.; Marri, G.; Glória, S.; Briante, G.; Chiattella, M. \& Re, A. (1986). Ambiente de Trabalho: A Luta dos Trabalhadores pela Saúde, São Paulo: Hucitec.

57) Offe, C. (1994). Trabalho: A Categoria Sociológica Chave? In: Capitalismo Desorganizado, São Paulo, Brasiliense, $2^{\mathrm{a}}$ edição, $5^{\circ}$ capítulo, p. 167-197. 
58) Otway, H. \& Thomas, K. (1982). Reflections on Risk Perception and Policy. Risk Analysis, 2 (2): 6982.

59) Porter, C.S. \& Corlett, E.N. (1989). Performance Differences of Individuals classified by Questionnaire as Accident Prone ou Non-Accident Prone. Ergonomics, 32 (3): 317-333.

60) Potter, J. \& Mulkay, M. (1985). Scientists' Interview Talk: Interviews as a Technique for Revealing Participants' Interpretative Práctices. In: M. Brenner, J. Brown \& D. Canter (orgs.) The Research Interview: Uses and Approaches, Londres: Academic Press, p. 247-271.

61) Potter, J. \& Wetherell, M. (1987). Discourse and Social Psychology: Beyond Attitudes and Behaviour, Londres: Sage.

62) Prilleltensky, I. (1994). The Morals and Politics of Psychology: Psychological Discourse and the Status Quo, Nova Iorque: State University of New York Press.

63) Queiroz, M.L.G.A. \& Novaes, J. (1980). Desenvolvimento de Escala para Medida de Atitudes frente à Segurança, Avaliação de Riscos e Uso de Equipamentos de Proteção. Arquivos Brasileiros de Psicologia, 32 (1): 74-88.

64) Rangel-Santos, M.L. (1992). "Cadê o Meu Aumento ou Vou Causar Acidente": Um Estudo de Caso da Cultura do Risco numa Indústria Petroquímica (Dissertação de mestrado em Saúde Comunitária Departamento de Medicina Preventiva da Universidade Federal da Bahia).

65) Ríos, M.F.; Moreno-Jimenez, B. \& García, L.G. (1987). El Stress en los Accidentes de tráfico. MAPFRE Seguridad, 7 (26): 13-20.

66) Rodrigues, M.S. (1984). O Acidente de Trabalho: Um Enfoque Psicológico, dissertação de mestrado. Instituto de Psicologia da Universidade de São Paulo.

67) Rose, N. (1990). Psychology as a 'Social' Science. In: I. Parker \& J. Shotter (orgs.) Deconstructing Social Psychology, Londres: Routledge, $7^{\circ}$ capítulo, p. 103-116.

68) Saad, E.G. (1976). Notas à Margem do XV CONPAT. Revista Brasileira de Saúde Ocupacional, 16 (4): 4-6.

69) Sampson, E.E. (1987). A Critical Constructionist View of Psychology and Personhood. In: H.J. Stam, T.B. Rogers \& K.J. Gergen (orgs.) The Analysis of Psychological Theory: Metapsychological Perspectives, Nova Iorque: Hemisphere, $2^{\circ}$ capítulo, p. 41-59.

70) Santos, L.A.S. (1991). O Trabalhador Imprevidente: Estudo do Discurso da Fundacentro sobre o Acidente de Trabalho, dissertação de mestrado, Programa de Pós-Graduação em Ciências Sociais da PUC-SP.

71) Sato, L. (1991). Abordagem Psicossocial do Trabalho Penoso: Estudo de Caso de Motoristas de Onibus Urbano. Dissertação de Mestrado. Programa de Pós-Graduação em Psicologia Social da PUC-SP.

72) Sato, L. (1992). O Psicólogo e a Saúde do Trabalhador na Área Sindical. In: F.C.B. Campos (org.), Psicologia e Saúde: Repensando Práticas, São Paulo: Hucitec, p. 103-121.

73) Shotter, J. (1992). Bakhtin and Billig: Monological Versus Dialogical Práctices. American Behavioral Scientist, 36 (1): 8-21.

74) Shotter, J. (1993). Bakhtin and Vygotsky: Internalization as a Boundary Phenomenon. New Ideas in Psychology, 11 (3): 379-390. 
75) Silva, L.F. (1995). Acidentes de Trabalho com Máquinas: Estudo a Partir do Sistema de Vigilância do Programa de Saúde dos Trabalhadores da Zona Norte de São Paulo, em 1991. Dissertação de Mestrado. Departamento de Saúde Ambiental da Faculdade de Saúde Pública da USP.

76) Singleton, W.T. (1973). Theoretical Approaches to Human Error. Ergonomics, 16 (6): 727-737.

77) Slovic, P. (1987). Perception of Risk. Science, 236: 280-285.

78) Spink, M.J.P. (1993). O Contexto como Pretexto, paper apresentado durante o XXIV Congresso Interamericano de Psicologia, Santiago do Chile, mímeo.

79) Spink, M.J.P. (1994). Desvendando as Teorias Implícitas: Uma Metodologia de Análise das Representações Sociais. In: S. Jovchelovitch \& P.A. Guareschi (orgs.) Textos em Representações Sociais, Petrópolis: Vozes, p. 117-145.

80) Spink, M.J.P. (1995). Representações Sociais e Práticas Discursivas: A Conversação como Produção de Sentido, paper apresentado na mesa redonda "O Enfoque da Representação Social na Psicologia Contemporânea", I Simpósio sobre Cognição Social, Universidade Gama Filho, Rio de Janeiro, mímeo.

81) Spink, M.J.P. (1996a). The Narrative Constitution of Social Selves: Re-Adressing Social Representations from the Perspective of Dialogical Inter Animation, paper apresentado durante o workshop "Social Representation: Questioning the State of the Art", London School of Economics and Political Sciences, mímeo.

82) Spink, M.J.P. (1996b). Social Representations and Discursive Practices: Integrating the Cultural, Social and Local Intersubjective Levels in the Production of Meaning, paper apresentado durante o simpósio "Methodological Problems in the Analysis of Social Representations", II ${ }^{\text {nd }}$ Conference for Social-Cultural Research / Vygotsky-Piaget, Genebra, mímeo.

83) Stam, H.J. (1990). Rebuilding the Ship at Sea: The Historical and Theoretical Problems of Constructionist Epistemologies in Psychology. Canadian Psychology, 31 (3): 239-253.

84) Szasz, A. (1984). Accident Proneness: The Career of an Ideological Concept. Psychology \& Social Theory, 4: 25-35.

85) Varela, C.R. (1995). Ethogenic Theory and Psychoanalysis: The Unconscious as a Social Construction and a Failed Explanatory Concept. Journal for the Theory of Social Behaviour, 25 (4): 363 385.

86) Vidal, M. (1991). A Evolução Conceitual da Noção de Acidente do Trabalho: Conseqüências Metodológicas sobre o Diagnóstico de Segurança. Cadernos DEP - Departamento de Engenharia de Produção, São Carlos, 13: 1-29.

87) Wagner, W. (1994). The Fallacy of Misplaced Intentionality in Social Representation Research. Journal for the Theory of Social Behaviour, 24 (3): 243-265.

88) Wagner, W. (1996). Queries about Social Representation and Construction. Journal for the Theory of Social Behaviour, 26 (2): 95-120.

89) Weisaeth, L. (1989). The Stressors and the Post-Traumatic Stress Syndrome After an Industrial Disaster. Acta Psychiatrica Scandinavica, 80 (supl. 355): 25-37.

90) Wünsch-Filho, V. (1995). Evolução e Perspectivas da Morbi-mortalidade dos Trabalhadores. In: C.A. Monteiro (org.) Velhos e Novos Males da Saúde no Brasil: A Evolução do País e de suas Doenças, São Paulo: Hucitec. 
91) Yin, R.K. (1989). Case Study Research: Design and Methods, Newbury Park: Sage, $2^{\mathrm{a}}$ edição revisada.

92) Zohar, D. (1980). Safety Climate in Industrial Organization: Theoretical and Applied Implications. Journal of Applied Psychology, 65 (1): 96-102. 


\section{ANEXOS}




\section{Anexo A: Questionário exploratório}

O questionário exploratório consistiu basicamente de duas perguntas abertas, a primeira versando sobre a causalidade dos acidentes de trabalho e a segunda, sobre sua prevenção ${ }^{49}$. Foi aplicado em 38 trabalhadores da produção, participantes de um curso de saúde e segurança oferecido pelo sindicato a membros de CIPA da região ${ }^{50}$.

É importante salientar que esse questionário não foi, de forma alguma, o principal instrumento de pesquisa utilizado neste trabalho, em razão de suas limitações para apreender os discursos explicativos em sua dimensão argumentativa, como será discutido adiante. Ele serviu, tão somente, como primeira aproximação da população estudada e como verificação da viabilidade da análise pretendida.

Os respondentes eram todos trabalhadores da produção oriundos de 22 empresas diferentes. Eram na sua maioria homens $(92,1 \%)$ e tinham idades que variavam de 22 a 51 anos, com média igual a 34,83 anos. Quanto à origem, 55,26\% nasceram na Grande São Paulo e $44,74 \%$ nasceram em outros estados.

Do total, $81,60 \%$ declarou ser sindicalizado, $76,30 \%$ declarou já ter feito algum tipo de curso relacionado à saúde e segurança no trabalho e 42,10\% (!) declarou já ter sofrido algum acidente, independentemente da gravidade.

Quanto à inserção nas Comissões Internas de Prevenção de Acidentes (CIPA), 84,30\% declarou ser $(71,10 \%)$ ou já ter sido $(13,2 \%)$ cipeiro.

Em geral, os trabalhadores que preencheram o questionário expressaram suas opiniões na forma de itens ou listas de causas ou formas de prevenção. Foram apontadas 44 causas para os acidentes e 27 formas de prevenção. Para a análise considerou-se a soma das vezes que cada uma apareceu, o que corresponde a 143 para as causas e 97 para as formas de prevenção.

As causas foram reunidas para análise em 6 grupos (tabela f): Fatores ligados ao ambiente físico de trabalho (32,17\%); Fatores diretamente ligados ao indivíduo (29,37\%); Falta de conscientização, informação ou treinamento (17,48\%); Fatores ligados à organização do

\footnotetext{
49 Outras perguntas foram incluídas procurando caracterizar a população submetida ao inquérito: idade, sexo, origem, escolaridade, profissão, tempo na profissão, empresa atual, tempo na empresa atual, sindicalização, ter sido membro de CIPA, ter feito curso de saúde e segurança, ter sofrido acidente.

${ }^{50}$ Outras 19 pessoas - em geral encarregados, técnicos de segurança do trabalho e engenheiros de segurança do trabalho - participaram do curso e responderam ao questionário. Por não estarem dentro do perfil previamente definido (trabalhadores da produção), não foram incluídos na análise.
} 
trabalho (16,78\%); Dificuldades impostas à ação da CIPA (2,80\%); Ineficiência da ação dos órgãos públicos $(1,40 \%)$.

Tabela F: Causas dos acidentes apontadas pelos trabalhadores da produção presentes em curso oferecido pelo sindicato - Questionário exploratório, $\mathrm{n}=38,1996$

\begin{tabular}{|l|c|c|}
\hline \multicolumn{1}{|c|}{ Causas dos acidentes } & Freq & \% \\
\hline Fatores ligados ao ambiente físico de trabalho (máquinas, EPI) & 46 & 32,17 \\
\hline Fatores diretamente ligados ao indivíduo (desatenção, preocupação) & 42 & 29,37 \\
\hline Falta de: conscientização, informação ou treinamento & 25 & 17,48 \\
\hline Fatores ligados à organização do trabalho & 24 & 16,78 \\
\hline Dificuldades impostas à ação da CIPA & 4 & 2,80 \\
\hline Ineficiência da ação dos órgãos públicos (legislação e fiscalização) & 2 & 1,40 \\
\hline \multicolumn{1}{|c|}{ Total } & 143 & 100,00 \\
\hline
\end{tabular}

O conjunto dos fatores humanos (individuais, conscientização, organizacionais) apontados como responsáveis pelos acidentes ${ }^{51}$ totalizam $63,63 \%$ do total de respostas, contra $32,17 \%$ dos fatores ambientais e $4,20 \%$ de outros fatores.

As formas de prevenção sugeridas, por sua vez, foram reunidas em 7 grupos (tabela g): Promover ações sobre o indivíduo: levar o trabalhador a tomar cuidado, ter atenção, usar EPI (26,81\%); Treinar, conscientizar ou informar o trabalhador $(24,74 \%)$; Promover modificações no ambiente de trabalho: máquinas, EPI (22,68\%); Aprimorar a ação da CIPA (10,31\%); Ações governamentais: legislação e fiscalização (8,25\%); Maior preocupação da empresa com a segurança (5,15\%); Aprimorar a ação sindical voltada para os acidentes de trabalho $(2,06 \%)$.

\footnotetext{
${ }^{51}$ Os fatores diretamente ligados ao indivíduos foram os seguintes: falta de atenção (8), deixar de usar EPI (6), preocupações fora do trabalho (5), cansaço (3), alcoolismo (2), ato inseguro (2), excesso de auto-confiança (2), insatisfação (2), condições psicológicas (1), negligência (1), erro humano (1), falta de responsabilidade (1), problemas de relacionamento na empresa (1), realização inadequada das tarefas (1), stress (1). O grupo "falta de treinamento, informação ou conscientização" englobou: falta de treinamento (16), falta de educação (2), falta de informação (2), falta de informação sobre EPI (2), falta de conscientização (2), desvio de função (1). Os fatores organizacionais foram os seguintes: pressão da chefia por produção (6) excesso de trabalho (4), descaso da empresa (4), falta de planejamento do trabalho (2), extensão da jornada de trabalho (2), ritmo intenso de trabalho (1), falta de comunicação (1), falta de regime duro (1), não aplicação de normas (1), não flexibilização das normas (1), salário baixo (1).
} 
Tabela G: Formas de prevenção apontadas pelos trabalhadores da produção presentes em curso oferecido pelo sindicato - Questionário exploratório, $\mathrm{n}=38,1996$

\begin{tabular}{|l|c|c|}
\hline \multicolumn{1}{|c|}{ Formas de prevenção } & Freq & \% \\
\hline Promover ações sobre o indivíduo (tomar cuidado, ter atenção, usar EPI) & 26 & 26,80 \\
\hline Treinar, conscientizar ou informar & 24 & 24,74 \\
\hline Promover modificações no ambiente de trabalho (máquinas, EPI) & 21 & 21,65 \\
\hline Aprimorar a ação da CIPA & 10 & 10,31 \\
\hline Ações governamentais (legislação e fiscalização) & 8 & 8,25 \\
\hline Modificações na organização do trabalho & 6 & 6,19 \\
\hline Aprimorar a ação sindical voltada para os acidentes de trabalho & 2 & 2,06 \\
\hline \multicolumn{1}{|c|}{ Total } & 97 & 100,00 \\
\hline
\end{tabular}

O conjunto de intervenções sobre os fatores humanos envolvidos nos acidentes propostas pelos sujeitos para fins de prevenção somou $57,73 \%$, contra $21,65 \%$ dos fatores ambientais e $20,62 \%$ de outros fatores.

A principal questão que se coloca em relação a esses dados é: qual valor têm em si essas distribuições? Sem dúvida, elas revelam a predominância de explicações centradas em fatores individuais nos discursos dos trabalhadores da produção; revelam também a presença de conceitos que há algumas décadas tiveram seu auge nos meios científicos, como por exemplo, os conceitos de ato inseguro e condição insegura, mas que hoje foram abandonados. Porém, afirmar que os trabalhadores atribuem os acidentes mais a causas humanas do que a outras causas (ambientais, por exemplo) não significa muita coisa se não forem investigadas as razões que os levaram a explicar dessa maneira ao responderem o questionário. Primeiro, porque a maioria dos sujeitos utilizou-se de diversos tipos de explicações e em muitos casos não apontaram quais explicações, dentre as apresentadas, que consideravam mais importantes. Segundo, deve-se saber se as explicações apresentadas nos questionários são utilizadas por seus autores no dia-a-dia ou, ainda, se suas ações concretas são orientadas por essas idéias.

Uma outra questão importante diz respeito ao aspecto argumentativo dos discursos. Ao ser respondido em itens (por opção de todos os sujeitos), o questionário não foi capaz de explorar essa dimensão. Assim, não foi possível com tal instrumento conhecer as relações que as diversas explicações estabeleciam entre si, as justificativas para a adoção de uma explicação em detrimento de outras e a forma como as explicações alternativas eram tornadas não convincentes. 


\section{Caro trabalhador:}

Esta pesquisa, feita por um pesquisador da USP com o apoio do sindicato, tem o objetivo de conhecer o que pensam os trabalhadores a respeito dos acidentes de trabalho. É muito importante saber o que você pensa, por isso pedimos que responda sozinho e com sinceridade às perguntas abaixo. Você não precisa se identificar se não quiser, basta que escreva a sua própria opinião.

Obrigado.

Fábio de Oliveira Pesquisador da USP

1.) Quais são, na sua opinião, as causas dos acidentes de trabalho?

2.) O que se deve fazer, na sua opinião, para evitar os acidentes de trabalho? 
3.) Nome:

4.) Qual a sua idade? anos.

5.) Sexo: Masculino ( ), Feminino ( ).

6.) Local de nascimento (Cidade e Estado):

7.) Escolaridade: Até que série você estudou?

8.) Qual a sua profissão?

9.) Há quanto tempo você está nessa profissão? anos meses.

10.) Em que empresa você trabalha?

11.) Há quanto tempo você trabalha na empresa atual? anos meses.

12.) Você é sindicalizado? Sim ( ), Não ( ).

13.) Com relação à CIPA:

Já foi "cipeiro", mas não é mais ( )

É "cipeiro" atualmente ( )

Nunca foi "cipeiro", mas pretende ser ( )

Nunca foi "cipeiro" nem pretende ser ( ).

14.) Já fez outro curso de CIPA alguma vez? Sim ( ), Não ( ).

15.) Você já sofreu algum acidente de trabalho? $\operatorname{Sim}($ ), Não ( ).

Que tipo de acidente você sofreu? 


\section{Anexo B: Roteiro de entrevista e observação}

\section{ENTREVISTA INDIVIDUAL}

1.1. Objetivos: Conhecer um pouco da história de cada entrevistado. Conhecer sua visão sobre os acidentes de trabalho. Conhecer suas experiências com acidentes (seus ou de companheiros).

\subsection{Preparação da entrevista:}

Informar que a empresa foi escolhida em conjunto com o sindicato da categoria e que o objetivo da entrevista é conhecer um pouco da vida dos trabalhadores e as coisas que eles pensam sobre os acidentes de trabalho. Informar que a entrevista será gravada, mas que o nome do entrevistado não será revelado. O trabalhador deverá sentir-se à vontade e deverá ser-lhe explicado que a entrevista vem a ser uma espécie de "bate papo", no qual o entrevistador está muito interessado no que o trabalhador tem para dizer, portanto as perguntas são apenas para começar a conversa, já que o entrevistador está lá mais para ouvir do que para falar e tudo o que for dito será de grande utilidade e valor.

Exemplos:

a) "Meu nome é Fábio, eu sou pesquisador da USP e estou aqui fazendo uma pesquisa para conhecer um pouco da vida dos trabalhadores metalúrgicos e as coisas que pensam sobre alguns assuntos";

b) "Eu vou conversar com trabalhadores de 3 empresas $^{52}$ daqui da região. Eu cheguei a esta empresa por indicação do sindicato";

c) "Eu não tenho ligação nenhuma com a empresa nem com a ISO 9000, sou da USP, onde faço pós-graduação, cheguei aqui através do sindicato";

d) "Para fazer a pesquisa, estou escolhendo pessoas ao acaso, aleatoriamente, igual pesquisa eleitoral ou do IBOPE. Assim, não me interessa o que uma pessoa específica pensa, mas o que o conjunto das pessoas pensam";

\footnotetext{
${ }^{52}$ A idéia de fazer um estudo de três empresas casos foi abandonada no decorrer da pesquisa.
} 
e) "Assim, tudo o que a gente conversar aqui vai ficar entre nós. As coisas que você me disser eu vou usar na minha pesquisa, mas ninguém vai saber que foi você que falou, pois pode ter sido qualquer pessoa de qualquer uma das empresas que eu estou pesquisando. Portanto, fique à vontade para dizer o que quiser".

\subsection{Perguntas norteadoras:}

a) Você poderia começar contando de onde veio, onde já trabalhou, a quanto tempo está aqui nesta empresa etc.

b) A minha pesquisa é sobre o que os trabalhadores pensam sobre o acidente de trabalho. Eu gostaria que você me falasse um pouco sobre os acidentes.

c) Por que os acidentes de trabalho acontecem? Quais são as causas dos acidentes de trabalho?

d) Explorar cada causa apresentada.

e) Você poderia dar um exemplo de um acidente que você tomou conhecimento? Como foi que aconteceu? Por que aconteceu? O que poderia ter sido feito para evitá-lo?

f) O que você acha da CIPA e do SESMT?

g) Qual sua opinião sobre o sindicato?

\subsection{Questionário complementar para trabalhador de base:}

1) Entrevista: ;) Iniciais:

3) Setor: ; 4) Fábrica: 123

5) Idade? ; 6) Sexo: Masculino ( ), Feminino ( ).

7) Onde nasceu (Cidade e Estado)?

8) Escolaridade?

9) Qual a sua profissão (função)?

10) Máquina:

11) Há quanto tempo você está nesta profissão (função)?

12) Há quanto tempo vocês está nesta empresa? 
13) Teve alguma outra profissão antes? Qual?

14) É sindicalizado?

15) Quanto à CIPA:

Já foi cipeiro:

; É cipeiro atualmente: ;Nunca foi cipeiro:

16) Já participou de algum curso sobre segurança e saúde (ex.: curso de CIPA etc.)?

17) Já sofreu algum acidente?

\section{ROTEIRO PARA OBSERVAÇÃO DA EMPRESA-CASO}

2.1. Objetivos: Conhecer o ambiente e as condições de trabalho dos trabalhadores entrevistados, enquanto parte do contexto enunciativo, isto é, enquanto um dos diversos determinantes de suas opiniões a respeito dos acidentes de trabalho.

\subsection{Preparação da observação:}

Contato prévio com a direção da empresa, através do sindicato, para combinar as visitas. Durante a visita, solicitar a presença do vice-presidente da CIPA. Explicar que o objetivo da pesquisa é conhecer o que os trabalhadores pensam sobre os acidentes de trabalho e que para isso é importante conhecer o local de trabalho sobre o qual os entrevistados falam. Outras solicitações: cópias de CATs e dos livros de atas de reunião da CIPA.

\subsection{Aspectos a observar:}

a) Número de funcionários na produção;

b) Matérias primas;

c) Produtos finais;

d) Nome dos setores que compõem a empresa;

e) Descrição do fluxo de produção;

f) Condições físicas gerais da empresa;

g) Condições gerais das máquinas, equipamentos e ferramentas;

h) Estratégias de segurança: 
- CIPA

- Comissão de fábrica

- SESMT

- Programas de higiene e segurança

- Programação de SIPAT e cursos de CIPA

- Uso de EPI

- Presença de EPC, proteções em máquinas

- Cartazes

- Outras;

i) CATs emitidas pela empresa;

j) Atas das reuniões de CIPA. 